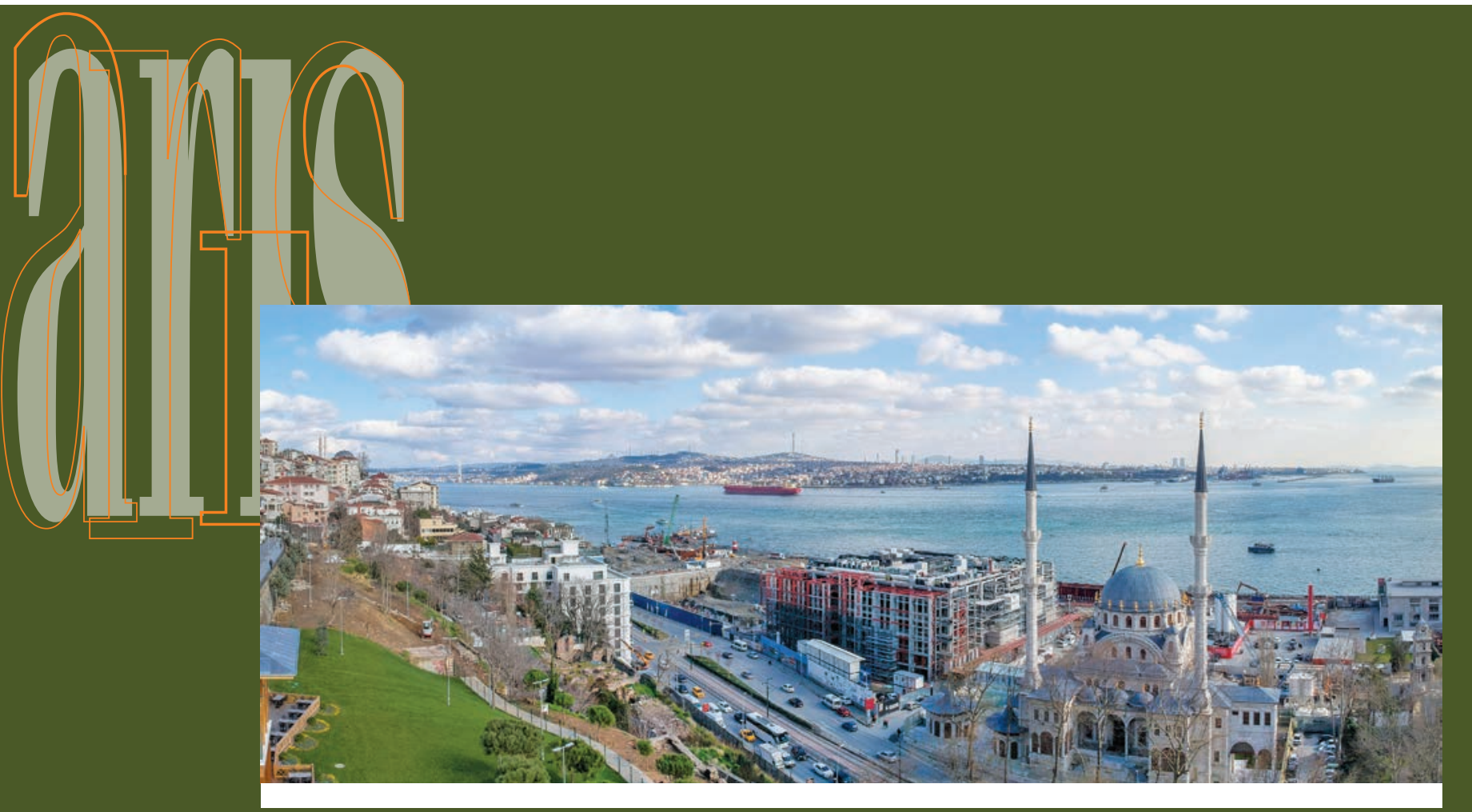

\title{
TARIHSEL KONUMU Ve MIMARISIYLE NUSRETIYE CAMii
}

\section{Dursun ARSLAN}

\section{öz}

Bu makalenin amacı, İstanbul'un Tophane semtinde yer alan Nusretiye Camii' nin gerek tarihsel konumu, gerekse dönemin önemli yenilikleri içinde nasıl bir yer tuttuğu ve inşasından günümüze geçirdiği yapısal değişimlere; sanat, mimari ve kültür tarihimiz açısından değinmektir. Beyoğlu'nun Tophâne semtinde, tarihî İstanbul'un sınırları dışında yer alan caminin inşasına 1823 yılının Haziran ayında başlanmış, 8 Nisan 1826'da tamamlanmıştır. Barok ve Ampir üslubun bir arada görüldüğü eser bir selâtin camidir. Bunun yanı sıra yapıyı farklı kılan özelliğ̈i; tarihsel konumu sebebiyle hakkında çok fazla politik yorumun olmasıdır. Caminin adı kitâbesinde Câmi-i Nusret şeklinde geçiyorsa da yapı, halk arasında genellikle Tophane Camii olarak bilinir. Nusret adının, dönemin önemli olaylarından biri olup sonrasında Vaka-i Hayriye olarak anılacak olan; Sultan II. Mahmud'un yeniçeri ocağını kaldırması münasebetiyle verildiği kabul edilmektedir. Fakat bu görüş bizi diğer tüm ihtimalleri yok saymaya götürmektedir. Sanat tarihi kaynaklarına "zafer" anlamıyla geçen "nusret" kelimesinin asıl anlamlarını ele alarak meseleye farklı bir bakış açısıyla yaklaşmanın faydalı olacağı kanaatindeyiz.

Anahtar Kelimeler: Osmanlı Mimarlığı, Sultan Mahmud II, İstanbul, Tophane, Nusretiye Camii, Camii.

* Marmara Üniversitesi Sosyal Bilimler Enstitüsü, İslam Tarihi ve Sanatları Anabilim Dalı Yüksek Lisans Öğrencisi. e-posta: dursun.arslan@outlook.com

Makale Gönderim Tarihi: 06.01.2018 / Makale Kabul Tarihi: 25.07.2018

ARIŞ HALI, DOKUMA VE IŞLEME SANATLARI DERGISi 


\section{ABSTRACT \\ NUSRETIYE MOSQUE WITH HISTORICAL LOCATION AND ARCHITECTURE}

The aim of this article is to comment on Nusretiye Mosque's -which is in Istanbul's Tophane district- historical location, its place in important innovations of its era and its structural changes which have been taken place since its first construction; through the terms of our art, architecture and cultural history. The construction of the mosque, located in Beyoglu's Tophane district, outside the borders of historical Istanbul, started in June of 1823 and was completed by the April 81826 . The mosque is a selâtin (imperial) creation in which we can see features of both baroque and imperial style. In addition to this another feature that makes the building different is, because of its historical location there is a lot of political commentary regarding the building. The name of Nusret (victory) is one of the important events of the period and will be referred as Vaka-i Hayriye in future and it is believed that the name was given as a reference for abolition of janisary corpses by Sultan Mahmoud II. However this view leads us to ignore all other possibilities. We believe that it would be more useful to approach the matter from another point of view that is by taking into account of main meaning of the word "Nusret" which means "victory" in the written publications of art history.

Key Words: Ottoman Architecture, Sultan Mahmoud II., Istanbul, Tophane, Nusretiye Mosque, Mosque

Beyoğlu'nun Tophâne semtinde, tarihî İstanbul'un sınırları dişında inşa edilen cami, 24 Şubat 1823 'te Tophane yakınında çıkan ve Dolmabahçe'ye kadar yayılan büyük yangında yanan, Top Arabacıları Kışlası ve Camii yerinde Sultan II. Mahmud tarafindan yaptırılmıştır ${ }^{1}$. İnşasına 1823 yılının Haziran ayında başlanan cami 8 Nisan 1826 'da tamamlanmıştır. Bir selâtin camii olmanın yanı sıra yapıyı diğer selâtin camilere göre onu farklı kılan özelliği boyutu ve etrafında çeşitli vakıf binaları yerine askeri yapılar yer almasıdır². Caminin adı kitâbesinde Câmi-i Nusret şeklinde geçiyorsa da yap1, halk arasında Tophane Camii olarak da anılmaktadır. Nusret adının "zafer" an-

1 Mehmed Raif yangın hadisesini şöyle aktarmaktadır: "1238 Cemaziyelahirinin on ikinci günü saat üçte Tophane kurbinden zuhur iden ateş, etrafina sirayetle ferdası günü saat yedi buçuğa kadar devam etmiş ve bu müddet zarfinda Dolmabahçe yakınına dek ilerülemiş, 48 cami-i şerif ile Arabacılar kışlası ve Tophane kışlalarının ikisi ve pek çok hane ve dükkân muhterik olduğu sırada bu cami-i şerif ile Tophane klşlasında olan mescid-i şerif dahi muhterik olmuştur." Bkz. Mir'at-ı İstanbul, İstanbul, H.1314, s.354.

2 Semavi Eyice, "Nusretiye Camii", TDV İslâm Ansiklopedisi, Cilt. 33, Ankara 2007, s. 274. lamında kullanıldığ 1 ve dönemin önemli olaylarından biri olup sonrasinda Vaka-i Hayriye olarak anılacak olan; II. Mahmud'un yeniçeri ocağını kaldırması münasebetiyle verildiği kabul edilip ${ }^{3}$, sanat tarihi kaynaklarına genel olarak bu şekilde aktariliyorsa da, biz bu kelimenin burada "Allah'1n yardımı" ya da "kurtuluş" anlamında kullanıldığını düşünmekteyiz. Nitekim kelimenin önde gelen anlamı "Allah'ın yardımı" dır ${ }^{4}$. Her şeyden önce kışlanın yanan camisinden kaynaklı bir ihtiyaç ortaya çıktığ 1 için bir cami inşa edilmeliydi. Tophane yangınının çok büyük hasarlara yol açtı̆̆ını düşündüğümüzde, yangınlarıyla ünlü İstanbul'un bundan daha vahim neticeler yaşamamış olması "Allah'ın yardımı" olarak görülemez miydi? Bir başka açıdan bakacak olursak; birçok dönemde isyanlarıyla devleti büyük sıkıntılara sokmuş ve artık kontrolü zorlaşmış bir askeri kurumun Sultan II. Mahmud'a kadar birçok kez kaldırılmasının ya da düzenlenmesinin düşünülmüş olması fakat bunun

\footnotetext{
3 a.g.e, s. 275.

4 Bkz. "nusret" - نصر ت - (a. i.) : 1. yardım. 2. Allah'ın yardımı. ץ. başarı, üstünlük. £. erkek adı. / Ferid Develioğlu, Osmanllca-Türkçe Ansiklopedik Lûgat, Ankara, 2018.
} 
bir türlü yapılamayışı, ancak Sultan II. Mahmud döneminde kaldırılabilmesi bir "zafer" olarak tanımlanabilir mi? Öyle düşünüyoruz ki; Osman11 İmparatorluğu hiçbir zaman kendi askerinin isyanını bastırmaya ya da disiplini bozulmuş bir kurumu islah etmeye "zafer" dememiştir. Ancak bu meseleye işlevselliğini yitirmiş bir sistemden "kurtuluş" olarak bakmak da mümkündür. Birçok araştırmada yer alan "nusret-zafer" ilişkisini bir de bu açıdan sorgulamı̧ olmanın konuya zenginlik kazandıracağ tırmalarda ve yayınlarda mimarının Krikor Amira Balyan $^{5}$ olduğuna işaret edilmekle birlikte mimarın Abdülhalim Bey olduğu da düşünülmektedir ${ }^{6}$. Bir başka görüşe göre; Balyan'ın karıştı̆̆ı, Gregoryen ve Katolik Ermeniler arasındaki ihtilaflı olaylar yüzünden 1822 yılında Kayseri'ye sürgüne gönderildiğini, dolayısıyla yapının planlanma aşamasında Payitaht'ta olmadığını belirten kaynaklar, yapının mimarlığını o dönemde başmimar olan Mehmet Rasim Ağa'nın üstlendiğini aktarmaktadır ${ }^{7}$.

Cami günümüze çevresel düzenlemeler ve çeşitli onarımlar geçirerek gelmiştir. Çevresel düzenlemeler hakkında bildiklerimiz genellikle caminin avlu duvarı ve etrafindaki yapılarla sınırlı kalmaktadır. 1850-1860 yılları arasında çekilen fotoğraflardan (Fotoğraf 1) anlaşıldığı üzere; yapının ilk şekliyle barok düzen pencerelere sahip yüksek avlu duvarları dış haremin sınırlarını belirlemekteydi.

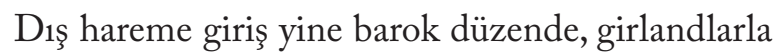
(askı) süslü ve kitabeli, dalgalı saçaklı kapılardan sağlanmaktaydı. Bu saçaklar kapıları örten kurşun külahın etekleriydi adeta. Aynı örtü biçimi muvakkithane, sebil ve şadırvanda da görülmektedir (Fo-

5 Balyan Ailesi için Bkz. Doğan Kuban, Osmanlı Mimarisi, İstanbul, 2016, s. 609-610. - Selman Can, Bilinmeyen Olaylart ve Aktörleri İle Son Dönem Osmanlı Mimarlı̆̆l, İstanbul 2010

6 Oktay Aslanapa, Osmanlı Devri Mimarisi, İstanbul, 2004, s. 510. - Yapının mimarı genel olarak Krikor Amira Balyan olarak aktarılmışsa, mimarın Abdülhalim Bey olduğunu aktaran kaynaklar mevcuttur. (Bkz. Mustafa Cezar, Osmanlı Başkenti Istanbul, İstanbul, 2002).

7 Selman Can, Bilinmeyen Olayları ve Aktörleri Ile Son Dönem Osmanlı Mimarlığg, İstanbul 2010, s. 99. toğraf 1). Kapilar Sultan Abdülaziz (1861-1876) devrinde cadde düzenleme çalı̧̧maları sebebiyle kaldırılmış, avlunun sınırları değişmiş, alçak duvarlar üzerine demir şebekelerin yerleştirildiği bir düzenleme ortaya çıkmıştır ${ }^{8}$ (Fotoğraf 2).

Yüksekçe bir platform üzerine inşa edilen caminin inşasında kefeki taşı ve mermer kullanılmıştır. Yapı kasr-1 hümâyûnu, sebili, muvakkithanesi ve şadırvanıyla kendi içinde küçük bir kompleks meydana getirmektedir. Son dönem cami tipolojisinde yerini almış olan hünkar kasırları, cuma selamlığında ibadet mekanı olarak kullanılmasının yanı sıra aynı zamanda padişahın dinlenmesi için tahsis edilmiş özel birimlere sahiptir. Kasr-1 hümâyûn caminin kuzey cephesinin iki yanına birer kanat halinde taşmakta ve dairevi kemerlerle birbirine bağlanan mermer sütunlara oturmaktadır. İki katlı olan kasrın zemin katında üst kata ç1kan merdivenler görülmektedir. Kasrın ikinci kat pencereleri caminin pencerelerinden farklı olarak dikdörtgen formda düzenlenmiştir (Fotoğraf 3). Batı kanadı padişahın kullandığı dairelerden meydana gelirken, doğu kanadı devlet erkanına ayrılmış, bu iki kanat harem kısmında bir ara mahfille birbirine bağlanmıştır.

Harem (harem-i enderun) dikdörtgen bir plan arz etmekle beraber yekkubbe bir örtü sistemine sahiptir (Çizim1). Kubbe dört büyük kemer üzerine, dairevi kemerli pencerelere sahip kasnağ ile oturmakta ve kubbeye geçişler aslan göğüsleri (pandantif) vasıtasıyla sağlanmaktadır. Kasnakta yer alan pencere düzeni bir pencere, bir payanda şeklinde devam etmektedir (Fotoğraf 4). Bu payandalar kasnak boyunca bir sütun düzeni göstererek "s" formunda devam eder, kubbeye ulaşır ve gövdesi armudi formlu alemlerle sonlanırlar. Buradaki alemler ile kubbe alemi arasinda form farklılı̆g görülmektedir. Söz konusu olan ve kubbeyi bir tacın çıkıntıları gibi tezyin eden alemlerin formu temel olarak; kaide, armudi gövde, yedi adet kıvrımdan oluşan bir bilezik ve son olarak yine

8 Eyice, s. 275. 
küre bir tepelikten müteşekkildir. Kubbe alemi ise klasik dönem hilallerinden farklı olarak uçları dışa bükülen ve merkezinde bir yıldız yer alan hilal formu olarak karşımıza çıkmaktadır. Gerek kubbe kasnağında yer alan "s" kıvrımlı payandalar, gerek armudi formlu alemler, gerekse kubbeyi taşıyan kemerlerin köşelerinde yer alan bektaşi kuleleri form açısından Osmanlı Mimarisi için Geç Barok etkisini bütüncül bir tema içerisinde yansıtmaktadır. Kemerleri taşıyan payelerin birer uzantısı olan bektaşi kuleleri Barok payandalarla kubbe kasnağına bağlanmaktadır. Bu kemerler uçlarında volütlerle sonlanmaktadır (Fotoğraf 4). Kubbeyi taşıyan dört adet büyük kemer tezyini olarak Barok ve Ampir-empire- üslubun niteliklerini taşımakla birlikte, kademeli bir şekilde oluk ve kaval silmelerle hareketlendirilmiştir. Kemer yüzeyi Batılilaşma dönemi mimarisi için öncü mahiyetinde olan Nuruosmaniye Camiin'nde gördüğümüz kubbeyi taşıyan kademeli silmeli kemerleri anımsatmaktadır (Fotoğraf 5). Bu silmeler küçük boyutlu konsol sırası ile taşınırken, kilit taşında yer alan kıvrımlı akantus yaprağı, kemerin etrafinı bir dantel gibi dönen mermer korkuluğun merkezinde yer alan yıldız motifi ile bir kontrast oluşturmaktadır ( $F_{0}-$ toğraf 4). Son dönem mimarisi için Barok, Rokoko, Ampir üslup ayrımına gitmek ne derece doğru bir yöntemdir, sorgulanmalıdır. Çünkü Batı'da birbirini takiben gelişen ve birer temeli olan bu üsluplar adeta toplu halde ithal edilerek Osmanlı Mimarisi’ne nüfuz etmiş, temelinin olmadığ 1 bir ortamda tutunmaya çalı̧̧ı̧ılardır. Bu durumda felsefi bir temeli olmayan bu üsluplar yoruma açık bir hale gelmiş, dolayısıyla birçok yapıda farklı halde uygulanabilmişlerdir. $\mathrm{Bu}$ açıdan bakıldığında Batıl1laşma dönemi mimarisi için hem Barok, hem de Ampir üslupların aynı yapıda görülebilmesi gayet tabii bir durumdur. Nusretiye Camii için Barok ve Ampir etkilerin örtü sisteminde yoğunlaştığ1$\mathrm{n}$, cephelerde ve minarelerde, haremde ve kasr-1 hümâyûnda görüldüğünü söyleyebiliriz.
Haremi örten kubbeden başka yapıda sadece kuzey cephede yer alan üç açıklıklı giriş sofasında kubbe kullanılmıştır (Çizim1). Burada kare kesitli sütunlar, kasr-1 hümâyûnun dikdörtgen pencereleri, girlandlı korkuluklar Ampir etkiyi ön plana çıkarırken, giriş sofasının tonoz ile değil de kubbe ile örtülmesi eski ile yeni arasında bir kontrast meydana getirmektedir. Kuzey cephe duvarı ve giriş sofası arasında tekne tonozlarla örtülü bölüm, haremi kuzeye doğru genişletmektedir. Caminin tüm cephe pencereleri ve kubbe kasnağındaki pencereler haremden bakıldığında toplam beş pencere sırası olarak yapıyı aydınlatmaktadır. Birinci sıra pencereler düz atkı kemerli iken diğer tüm cephe pencereleri yuvarlak kemerlidir. Doğu ve Batı cephelerinde yan sofaların hemen üstünde görülen pencere sırası birbirinden kare kesitli sütunçelerle ayrilır. Pencerelerin yuvarlak kemerinde, kilit taşından başlayarak bir vazodan çıkarcasına yanlara ve yukariya yayılan yüksek kabartma stilize yapraklar cephede hareketliliği sağlayan önemli bir faktördür. Bu yapraklardan ortadaki yukarı doğru uzarken, iki yanında akantus yaprakları aşağı doğru sarkarak kıvrılır. Caminin batı cephesinin bir kısmı kasr-1 hümâyûnun kanadı tarafindan kesintiye uğramaktadır (Fotoğraf 6). Cephe düzeninin kesintisiz bir şekilde görüldüğü tek cephe doğu cephesidir (Fotoğraf 7). Güney cephede hakim unsur dışarı çıkıntı yapan mihrap nişidir. Diğer tüm cephelerden farklı olarak sadece mihrap cephesinde mihrap nişinin yarım kubbesi hizasına yerleştirilen iki pencere fil gözünü andıran fakat elips formlu pencereler olarak düzenlenmiştir. Dişa taşkın mihrap nişi yüzeysel nimpayelerle beş sağır nişe ayrılmakta ve her nişte birer pencere olmak suretiyle iki pencere sırası oluşmaktadır.

Caminin ikişer şerefeli iki minaresi vardır. İlk yapılan minareler arasına kurulan mahya ile kubbe arasında yeterli mesafe olmadığından minareler daha yüksek yapılmak maksadıyla 1826 yılının Ekim ayının altıncı gününde alt şerefeye kadar 
y1kılıp yeniden inşa olunmuştur'. Minarelerin kaideleri masif bir şekilde yükselmekte ve armudi formlu pabuç kısmına geçilmektedir. (Fotoğraf 3). Pabuçlar üzerinde akantus yaprağı işlemeli kalın damarlar yer almaktadır. Bu damarlar minare gövdesine geçişte volütlerle sonlanır. Silindirik minare gövdesi yivli bir düzenlemeye sahiptir. Şerefe altına kadar kesintisiz devam eden yivler burada kesilir ve önce girlandlı bir friz, sonra bir bilezik, akabinde stilize yaprak dolgusu ile şerefe kısmı gelmektedir. Şerefe korkulukları dalgalı bir forma sahiptir ve üzerinde yine girlandlı bir kompozisyon görülmektedir (Fotoğraf 7). Birinci şerefeden sonra devam eden silindirik gövde üzerinde yivler tekrarlanmakta ve ilk şerefe düzenini tekrarlayan ikinci bir şerefe gelmektedir. Petek kısmı gövdenin yivli formunu devam ettirmekte ve külah kısmına doğru yine girlandlı bir friz ile son bulmaktadır. Külah ise gövdenin yivli formuna uygun olarak kurşunla kaplanmış ve tepede bir alem ile taçlandırılmıştır.

Hareme giriş kuzey cephede yer alan basık kemerli cümle kapısından yapılmaktadır (Fotoğraf 8). Bunun haricinde caminin doğusunda bir hünkar kapısı mevcuttur (Fotoğraf 9). Aynı zamanda giriş sofasından yan sofalara geçit veren iki kapı (Fotoğraf 10) ve bu sofalardan hareme açılan kapilar mevcuttur (Fotoğraf 11). Doğu sofasında ise kasr-1 hümâyûna çıkan merdivenler görülmektedir. Üç kubbeli giriş sofasına -Barok mimaride sıklıkla görülen- iki yönde kıvrımlı merdivenlerle ulaşılmaktadır (Fotoğraf 12). Burada korkuluklar üzerinde girlandlar görülür. Merdivenin bulunduğu bölümde iç içe geçen dairelerden müteşekkil bir korkuluk yer alır. Kare kesitli sütunların başlıklarında volütleri birbirine bağlayan bir girland ve bu girlandın ortasında bir salkım üzüm, alt kısmında bir yaprak sırası bulunmaktadır. 2018 onarımlarında giriş sofası dairevi kemerlerinin arasına çelik gergiler yerleştirilmiştir. Sütun başlıklarında, kapı

9 Ayvansarayi Hüseyin Efendi, Hadikatü'l Ceva-mi, Hadikatü'l Ceva-mi (2. Bölüm), İstanbul, H. 1281, s.64. alınlıklarında genellikle kenger ve akantus yaprağının hareketli, "s-c" kıvrımlı kompozisyonları görülmektedir. Giriş sofasındaki bir başka tezyinat öğesi kalem işleridir. Camiinin kalem işleri doksanlı y1llarda yapilan onarımlar ${ }^{10}$ ve 2018 y1lında tamamlanan onarımların ürünüdür. Kalem işleri; kubbeye intikali sağlayan aslan göğüslerinde, kubbe içinde, eteğinde ve pencere alınlıklarında görülmektedir. Özellikle örtü sisteminde gördüğümüz kalem işi tezyinatta hakim renk turuncu ve beyaz olmakla birlikte turkuaz ve kırmızının tonları kullanılmıştır. Burada kullanılan motifler Türk İslâm motiflerine yabancı unsurlardır. Revak kemerleri iç yüzeyinde görülen kalem işlerinin genel teması; kartuşlar içinde beş uçlu stilize yaprakların cepheden ve profilden tasviri ile kabara motiflerinin tekrarlanmasıyla oluşturulmuştur. Kubbelerinin geçişinde kullanılan aslan göğüslerinde kalem işi teması; üçgen yüzeye yayılan stilize bitkisel motifler ve yine düğümlü geçmeli kompozisyon merkezinde istiridye formlu bitkisel motifler şeklindedir (Fotoğraf 13). Kubbelerin eteklerinde ise palmetlerle sonlanan stilize bitkisel motifler görülürken, bu kubbelerin merkezinde yine uçları palmetlerle son bulan çok kollu bir kompozisyon bulunmaktadır. Giriş sofasında kalem işi süslemenin dışında taş bezeme önemli bir yer tutmaktadır. Bilhassa cümle kapısı ve yan sofalara geçilen kapılar taş tezyinat açısından dikkat çekicidir. Cümle kapısı dıştan içe kademeli sütunçeli düzenleme içine yerleştirilmiştir. Bu sütunçeler yaklaşık 30 santimlik bir kaideler üzerine oturmaktadır. Sütun başlıklarında yukarıda anlattığımız şekilde, volütleri birbirine bağlayan bir girland ve bu girlandın alt kısmında yaprak frizi görülmektedir. Sütunçelerin gövdeleri nimpaye gibi düzenlenmiş ve yarım gövde olarak yüzeyden birkaç santim yükseltilmiştir. Sütunçelerin başlikları form açısından kare kesitli olmayıp yarım daire formundadır. Cümle kapısı en tepede bir taç kısmı ile başlar. Burada kenger yapraklarından müteşekkil oval bir madalyon $\overline{10 \text { Eyice, s. } 275 .}$ 
görülmektedir. Esasen bu madalyonun içinde II. Mahmud'un tuğrasını görmek beklenirdi fakat bir tuğra vard 1 ise de akıbeti bilinmemektedir. Madalyonun çevresi kabarık ve kıvrımlı akantus yapraklarıyla çevrelenmiş ve tüm bu unsurlar taç kısmına üçgen bir form kazandırmıştır. Akantus yapraklarının kalın dalları belirgin bir halde ele alınmış, sağda ve solda bu dalların ucu kıvrılarak volütler halinde sonlandırılmıştır. Taç kısmının hemen altında yapının inşa kitabesi yer almaktadır (Fotoğraf 14). Mermer kitabe taç kısmından bir korniş ile ayrılmış, iki yanda "c" kıvrımlı volütlü akantus yaprakları ile çerçevelenmiştir. Kitabe dört bölüme ayrılmıştır ve toplam 24 kartuştan oluşmaktadır. Kitabenin hemen altında sütunçelerin taşıdığ 1 iki korniş arasında bir dizi gül frizi görülmektedir. $\mathrm{Bu}$ güller-kabaralar kapı ve pencere sövelerinin köşelerinde de kullanılmıştır. Karakteristik özellikleri; içe doğu kıvrılan yapraklarıdır ve bu kabaraları dönemin bir çok yapısında görmek mümkündür -günümüz İstanbul Valiliği olan, dönemin Bâb-ı Ali'sinin Gülhane tarafina bakan kapısı gibi-. Alt tarafta basık kemerin ortasında bir kilit taşı görülür. Kemer ile sövelerin birleştiği noktada minder yoktur. Yukarıdaki gül frizinde gördügümüz kabaraların boyut olarak daha büyükleri kemer ile sövenin birleştiği noktalara yerleştirilmiştir. Kemer ve frizli lento arasında kalan köşe kısımları volütlü bir merkezden dağılan akantus yapraklı kompozisyonlar ile doldurulmuştur. Cümle kapısının ahşap kapı kanatları son derece sadedir. Cümle kapısının iki yanında üçer pencere iki sıra olarak yerleştirilmiştir. Bunlardan birinci sıradaki iki pencere dikdörtgen formdadır. Mermer sövelerin köşelerinde cümle kapısında kullanılan kabaralar kullanılmıştır. Bu pencerelerin yuvarlak kemerli alınlığı dış bükey bir bordür ile sınırlanmaktadır. Son onarım çalışmalarında bu alınlıklara gri tonlarında, ortada bir vazoya bağlanan girlandlar ve iki yana uzanan stilize yapraklar olmak üzere yeni bir kalem işi programı uygulanmıştır. Fakat bu kalem işleri tamamen son onarımın ürünüdür. Üst sıra pencereleri ise cümle kapısının kemer formunu tekrarlar. Söve köşelerinde kabaralar mevcuttur. Giriş sofasının tüm pencereleri devrinin özelliklerini yansıtan metal şebekelere sahiptir. Mustafa Rakım Efendi'ye ait ta'lik hattıla yazılan kitabe Hadîkat'ül Cevâmi' de şu şekilde aktarılmıştır ${ }^{11}$ :

\section{Topdan Tophâne'yi âbâd kıldı pâdişâh}

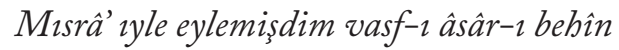

Câmi'i kalmışdı ancak an da tekmîl idüb

Secde-i şükr itdi Mevlầya cünûd-ı müslimîn Görmedik mislin bi-Rabbil-Ka'be bu nev câmi'in

İsite işite dünyâ âsâr-ı selâtîn-i güzîn Varsa çarbın beyt-i ma'mûrı bu da sânîsidir Ba'd-ezin eflâke fahr itse nola rû-yz zemîn Eyledi mibrâbına çâk-i girîbân âsumân

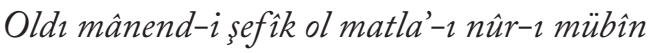
Minber oldu arş̧- Rabmâna mu'alla nerdbân Gelse şâyândır hitâber itmeğe Rûbül- emin Oldı her bir zerkârî birer mibr-i felek Ziynet kürsîsidir reşk-i sipibr-i çârü̈mîn İki serv-i bâ̆ğ-ı dîn oldı minâreyn-i bülend Ser-nigûn-i reşkidir tûbâ-yı Firdevs-i berîn Câmi'i Nusret ola nâmı bu vâlâ ma'bedin Eyleye bânîsini mansûr Rabbül- âlemîn Haşredek dergâbını zâtıyle Mevlâ eylesün Kıble-i ikmâl-i âlem muktedâ-yz ebl-i dìn Vaktini hayr ü gazâya sarfdan dûr olmadi Kişlada bu ma'bedinden fark ider ehl-i yakin İzzet ol beyt-i Hudầnın söyledim târibini Câmi'-i Mabmûd Hân oldı mutâf-ı müminîn, 1241

Kitabede son misra tarihi vermektedir ve harfler ebced hesabına göre 1241 yılını göstermektedir. Yan sofalara geçen kapılar giriş sofasında sağda ve solda karşılıklı aynı aks üzerine yerleştirilmiştir. Cümle kapisina oranla daha sade bir düzenleme

11 Ayvansarayi Hüseyin Efendi, Hadîkat'ül Cevâmi İstanbul Camileri ve Diğer Dini Sivil Mimari Yapılar, İstanbul, 2001, s. 463. 
izlenen bu kapılar düzen açısından birbirini tekrarlar. Düz atkı kemerin sövelerle birleştiği köşelerde yine uçları içbükey olarak dışa taşırılmış kabaralar görülür. Tepede akantus ve kenger yapraklarından mürekkeb bir taç mevcuttur. Üçgen formlu tacın tepesinde soyut yapraklardan oluşan bir düzenleme vardır. Buradan çıkan kıvrımlı yapraklar tacı çevrelemektedir. İki yanda içe doğru kıvrılan akantus yaprakları görülür. Taç kısmının hemen altında bir kitabe mevcut olmakla birlikte kitabe altta ve üstte kornişlerle, iki yanda ise "s" kıvrımlı akantus yapraklı bir düzenleme ile çerçeve içine alınmıştır ve koyu zemin üzerine altın varaklıdır. Bu kapılardan sol taraftakinin kitabesinde Tirmizi'den aktarılan bir Hadis-i Şerif yer alır $^{12}$ (Fotoğraf 15). Kapının diğer yüzünde daha basit bir düzenleme görülür. Burada yüzeyi ince profillerle hareketlendirilmiş söveler, düz atkı kemer ve kitabeden müteşekkil bir kapı söz konusudur. Buradaki kitabede ise Buhari'den aktarılan bir Hadis-i Şerif görülür ${ }^{13}$ (Fotoğraf 16). Sağ taraftaki kapının kitabesinde ise "Her emire itaat et. Her imamın arkasında namaz kıl." ibaresi karşımıza ç1$\operatorname{kar}$ (Fotoğraf 17).

Hünkar kapısı batı tarafta kasr-1 hümâyûna geçiş sağlamaktadır. Barok unsurların ağırlıkta olduğu bir düzenlemeye sahiptir (Fotoğraf. 9). İki yanda kare kesitli sütunçeler ikişerli olarak yerleştirilmiştir. $\mathrm{Bu}$ sütunçelerin kaideleri ortaktır. Barok etkisini vurgulayan dalgalı saçağın altında akantus yaprakları ve stilize bitki motifleriyle oluşturulmuş bir bezeme kompozisyonu görülür. Burada tek merkezden 1şınsal kompozisyonda dağ1lan bitki motifleri dikkat çekici olup, Mabmud Güneşi olarak anılan 1şınsal kompozisyonlara bir gönderme yapmaktadır. Saçağın hemen altında yine akantus yapraklarının son derece kıvrımlı ve hareketli bir çerçeveyle oluşturduğu madalyon içerisinde "Allah te'ala buyuruyor ki." ibaresi yer alır. Bu ibare alttaki ayet kitabesine atıfta bulun-

\footnotetext{
12 Mevârit 13. : "Amellerin en hayırlısı ilk vaktinde kılınan namazdir.".

13 Mevâkit 26. : "İki serinlik namazını kılan kimse cennete girer.".
}

maktadır ${ }^{14}$. İki korniş arasında alınan kitabe diğer kapılarda olduğu gibi iki yanda stilize bitkisel motiflerle sınırlanmıştır. Kitabe koyu zemin üzerine altın varaklıdır ve ayetin sonunda Mustafa Rakım Efendi'nin imzası "Ketebehû Mustafa Rakım" şeklinde yer alır. Hemen altında yer alan frizde tıpkı cümle kapısında gördüğümüz gibi uçları iç bükey kıvrılan güllerden müteşekkil bir friz yer alır. Bu motiflerin arasına girlandlar yerleştirilmiştir. Kapı kemeri Barok vurgunun güçlendiği bir noktadır. Dalgalı bir forma sahip olan kemeri dilimli kemer olarak nitelendirmek mümkündür. Cümle kapısında olduğu gibi köşelerde kalan boşluklar son derece hareketli kıvrım yapraklarla doldurulmuştur. Diğer kapılardan farklı olarak kemerin sövelere oturduğu kısımda kabara yerine basit profilli minderler kullanılmıştır. Ahşap kapı altta ve üstte kartuşlarla hareketlendirilmiştir.

Cümle kapısından hareme (barem-i enderun) geçildiğinde haremi kuzeye doğru genişleten bir bölüm görülmektedir. Tonozlu birimlerin bulunduğu bölüm iki katlı olup üst kat mahfil olarak düzenlenmiştir. Bu mahfil bölümü aynı zamanda kasr-1 hümâyûnun doğu ve batı kanadını harem içinde birbirine bağlayan bölümdür. Mahfil bölümü dıştan tekne tonoz, içten eliptik kubbelerle örtülmüştür. Mahfilin orta birimi diğer iki birime oranla daha geniş tutulmuştur. Mahfilin korkuluk levhaları giriş sofası korkuluklarında olduğu gibi girlandlarla bezenmiş olup orta birimin korkuluğunu hareme doğru oval formlu bir çıkıntı oluşturmaktadır. Mahfil katını zemin katta iki büyük "t” kesitli paye ve bunların arasında daha küçük iki kare kesitli paye taşımaktadır. (Fotoğraf 18). Üst kat mahfilinin altında girişin sağlı sollu iki yanında bugün müezzin mahfili ve bayanlar mahfili olarak kullanılan maksureler vardır ve geç dönem eklemeleridir. Bu maksurelerin olduğu kısımlardan yani girişin sağlı sollu iki yanında üst kata ç1-

14 Mü'minûn Suresi 29. Ayet: "Rabbim! Beni bereketli bir yere indir; en uygun şekilde indirip yerleştiren sensin.”. 
kış veren yuvarlak kemerli açıklığı ile iki merdiven görülür.

Harem kubbe kasnağındaki pencereler dahil olmak üzere toplam beş pencere sırası ile aydınlanmaktadır. Haremde kalem işi bezemenin görüldüğü bölgeler genellikle ana kubbe ve mahfil eliptik kubbelerinin içi, intikal unsurları, pencerelerin etrafidır. Daha evvel de belirttiğimiz gibi yapının kalem işi programı önce doksanlı yıllarda yapılan onarımlar, daha sonra 2018 yılı onarımları sonucu değişmiştir. Özellikle harem kısmında bulunan kalem işi tezyinat tamamen farklı bir programla ele alınmıştır. Günümüzde harem duvarlarının mermer kaplı alt seviyesinden sonrasına sıva üzerine kalem işi uygulanarak mermer görünümü kazandırılmıştır. $\mathrm{Bu}$ vesile ile tarihi eserlerimizin onarımlarında uygulanan tezyinat programlarının günümüzde inşa olunan yeni bir camide görebileceğimiz tezyinat programlarından pek farkı olmadığını görmüş oluyoruz. Yapının 2018 onarımından önceki halini gösteren ve günümüz halini gösteren iki fotoğrafi sizlerle paylaşmak daha somut bir etki oluşturacaktır (Fotoğraf 19-20). Kuşak yazısının üzerindeki tüm pencereler kalem işi ile tezyin olunmuştur. Yuvarlak kemerli pencerelerde kalem işi kenar suyu (bordür) pencerelerin iki yanına uygulanmıştır. Pencerelerin üstünde ise alt sıra pencerelerinin mermer alınlıklarında gördüğümüz kompozisyona benzer bir süsleme kompozisyonu kalem işi olarak uygulanmıştır. Aslan göğüsleri üzerinde Allah (Cc.), Hz. Muhammed (Sav.), Hz. Ebu Bekir ve Hz. Ömer (Ra.) isimleri çelenkli madalyonlar içinde koyu zemin üzerine altın varaklı olarak yazılmıştır. Kubbe kasnağının hemen altında yer alan kafa tahtı (kedi yolu) yaprak bezemeli küçük konsollarla desteklenmektedir. Burada demir korkuluklar tavus kuşu figürünü andıran stilize bir motifle oluşturulmuştur. Demir korkuluklar birbirinden kare kesitli mermer babalarla ayrılmıştır. Kubbenin merkezinde yer alan yaprak motifli dekoratif madalyon altın yaldızlıdır. Kubbede görülen kalem işi bezemelerin geç dönemlerde değiştiği onarımlar esnasında çekilen bir fotoğraftan anlaşılmaktadır (Fotoğraf 21). Günümüzde kubbe yüzeyinde gördüğümüz kalem işleri üst üste binen sıva katmanlarının altında ç1kan ve kronolojik olarak daha erken bir dönemi işaret eden özelliklere sahiptir (Fotoğraf 22). Alt sıva katmanlarında görülen kalem işi kompozisyon günümüzde üzerinden geçilerek yenilenmiştir. $\mathrm{Bu}$ kalem işleri, yapı ile Ampir üslubu arasında; koyu renkler ve pastel tonlarla, yer yer girlandlar, püsküllü perdeler ve stilize bitkisel motiflerden müteşekkil bir kompozisyon ile uyumlu bir şema oluşturmaktadır.

Zemin katı ve ikinci katı belirten silme haremi çepeçevre dolanmaktadır. Birinci silmeye kadar harem duvarları mermer ile kaplanmış olup bu kat pencereleri tabii olarak diğer pencerelerden hem malzeme hem de tezyinat olarak farkl11,k arz eder (Fotoğraf 24). Söz konusu pencerelerde en dikkat çeken tezyinat unsuru merkezde yer alan süslü bir vazodan birer kulp uzantısı gibi yanlara uzanan kıvrık dallı kompozisyondur. Kompozisyon dış bükey bir bordür ile sinırlanan yuvarlak kemerli alınlığın merkezinde yer almaktadır (Fotoğraf 24). Geçmişini Antik Dönem'e kadar götürebileceğimiz bu motif şüphesiz ki Batılilaşma dönemi mimarisine Avrupai etkilerle birlikte gelmiştir (Fotoğraf 25). Bu durum tarihin tekerrür etmesine güzel bir örnektir. Böylelikle ikinci kez aynı motif İslam Mimarisi içinde kullanılmıştır. Diğer bir örneği ise Emeviler Dönemi'nde Kubbetüs Sabre'de görülmektedir. Pencerelerin hem taş tezyinat1 hem de altın yaldızları Barok üslubun süslemeci eğilimine güzel bir örnek teşkil etmektedir.

Alt1 sira pencerelerin biraz üstünde Mustafa Rakım Efendi'nin son dönem hatlarından olan yazı kuşağı mahfil katı hizasında, hünkar mahfilinin dışa taşan kafesinin dibinden başlayıp kesintisiz bir şekilde köşe payesine kadar devam eder. Burada küçük bir kesintiden sonra minber külahının arkasından devam ederek mihrap sofasına (şah niş) ulaşır. Burada nimpayeler tarafinda kesi- 
len kuşak, sofaya geçiş yaptığında iç bükey bir yüzey üzerinde ilerler, mihrap aksına yakın bir yerde "s" (deve boynu) çizerek esas seviyesinden yükselir, mihrap aksı boyunca devam ettikten sonra tekrar "s" çizerek esas seviyesine geri döner ve aynı şekilde mahfil katına kadar ilerlemeyi sürdürür (Fotoğraf 26). Mustafa Rakım Efendi'nin Nusretiye Camii hatları, hem kendisinin hem de Osmanlı Hat Sanatı'nın en olgun eserlerinin içinde değerlendirilmelidir. Celi sülüs hat ile koyu zemine hakkedilen yazılar altın varaklıdır. Haremde kuşak yazısından başka hat örnekleri mihrap ve minber üzerinde, yan sofalara geçiş kapılarının kitabelerinde, üst kat mahfilinde kasr-1 hümâyûnuna geçiş kapılarının kitabelerinde ve kuzeydoğu payesi üzerinde kuşak yazısının sonunda konumlanmış eliptik bir madalyonun içinde yer alan hattat imzası olarak karşımıza çıkmaktadır. (Fotoğraf 27).

Mermer mihraba baktığımızda dönemi itibariyle öncülü ve ardılı olacak mihraplara oranla sade bir düzenleme göstermektedir (Fotoğraf 28). İç bükey bir şahniş içine yerleştirilen mihrabın yanlarında kare kesitli ve dairevi sütunçeler görülür. Bombeli kaideleri akantus yapraklarıyla müzeyyendir. Sütun başlıkları karakteristik açıdan yapının diğer sütun başlıklarını tekrarlamaktadır. Mihrap kavsarası dairevi kemerli olup yedi dilimlidir. Kavsarada tek süsleme unsuru kavsaranın merkezinde yer alan istiridye formlu bir yaprak motifidir ve köşelikler yaprak motifleriyle doldurulmuştur ${ }^{15}$. Mihrabın taç kısmı, birinci sıra pencerelerinin alınlığında olduğu gibi vazo ve ondan çıkan "c-s" kıvrım dal ve yapraklardan oluşan kompozisyonun tekrarından ibarettir. Hemen altında mihrap kitabesi yer almaktadır. Kitabede Âl-i İmrân Suresi'nin 39. Ayeti Mustafa Rakım Efendinnin kalem-i eseridir. Camide Rakım Efendi'den başka, Mehmed Haşim ve Recâi Şâkir efendilerin hatları mevcuttur ${ }^{16}$. Mihrabın iki yanında armudi formda bir tür yeşil mermerden yapılan şamdanlar

15 Âl-i Imrân Suresi'nin 39. Ayet: "O mâbedde durmuş namaz k1larken melekler ona şöyle seslendiler.”.

16 Eyice, s. 275. altın varaklı olup dönemin özelliklerini göstermektedir.

Mermer minber klasik ölçülere bağlı kalmakla birlikte tezyinatta yoğun bir Barok ve Ampir etkisi izlenir (Fotoğraf 29). Minber kapısında kabarık bir palmet gibi düzenlenen taç kısmına, akantus yapraklarının "s-c" kıvrımları ve volütlü hareketler Barok bir özellik kazandırmıştır. Tacın hemen altında yer alan aynalık kısmındaki kitabesinde, yine koyu zemin üzerine varaklı "Kelime-i Tevhid" mahkuktur (Fotoğraf 30). Kitabe yanlarda akantus yaprakları ile sınırlanmıştır. Korkuluk birbirini takip eden akantus yaprakları ve çan çiçekleri ile kırık çubukların oluşturduğu bir zikzak hatını takip ederler. Üçgen aynalık lotus, palmet ve akantus yapraklarından mürekkeb bir demet düzenlenmesi ile karşımıza çıkmaktadır. Minberin altındaki süpürgelikte yuvarlak kemerli pencerelerin arasında sütunlu bir düzenleme görülmektedir. Pencereler zeytin ve defne yapraklı bordürlerle çevrelenmekte, dekoratif sütunlar stilize yapraklar ile hareketlendirilmektedir. Minberin gösterişli köşkünü yine kare kesitli sütunlar taşımaktadır. Sütun başlıkları bitkisel düzenlemeleri ve volütleri ihtiva eder. $\mathrm{Bu}$ sütun başlıklarının arasına girlandlar gerilmiştir. Düz atkılar ve kaval silmesi ile hareketlendirilen platform üzerinde kaburgalı külah yükselmektedir. Tepede alemle sonlanan külahın başlangıcında dalgalı ve yapraklarla süslü bir friz görülür. Külah altın yaldızla süslenmiştir. Külahın yükseldiği platformun dört tarafinda bitkisel düzenlemeli taçlar yer alırken, köşelerde kozalak formunda topuzlar görülmektedir. Minberin altındaki geçit basit bir şekilde düzenlenmiş yuvarlak kemerli bir kapı şeklindedir.

Mermer vaaz kürsüsü haremin doğu duvarında konumlandırılmıştır (Fotoğraf 31). Dalgalı bir forma sahip olan kürsünün gövdesi genel olarak üç frize bölünmüştür. Orta friz süslemesiz birakılmıştır. Süsleme unsuru olarak akantus yaprağ1 motifi yoğunluk göstermekle birlikte ritmik bir sıra ile birbirini tekrar eden demetler şeklinde 
kullanılmıştır. Kürsü ile zemin ilişkisi bir ayakla sağlanmıştır. Yuvarlak kemerli nişi pencerelerin alınlığına kadar devam etmektedir. Bu kemerin akantus yapraklarıyla bezeli bir kilit taşı vardır.

Mahfil-i hümâyûn, kasr-1 hümâyûnun batı kanadında yer almakta ve kafesi hareme doğru çıkınt1 yapmaktadır (Fotoğraf 32). Üsküf (taç) kısmında sirayla kozalak formlu topuzlar ve akantus yapraklarından müteşekkil demetler kullanılmıştır. Sütun başlıklarının arasına gerilen perde motifli bir friz görülmektedir. Cephesi kare kesitli sütunlarla üçe ayrılan mahfil-i hümâyûnun köşeleri oval olarak dönülmüştür. Korkuluğunda girlandlı ve frizli bir düzenleme görülmektedir. Armudi forma sahip sütunçe kaideleri akantus yapraklarıyla hareketlendirilmiştir. Mahfil-i hümâyûnun kafesi yekpare pirinçten ve altın varaklıdır ${ }^{17}$. Pirinç kafes mahfili tam kapatmaz. Mahfilde genel itibariyle Ampir üslubun yoğun olduğu söylenebilirse de Barok etkinin devam ettiğini vurgulamak gerekir.

Muvakkithane ve sebil ilk zamanlar caminin karşısında konumlandırılmışken, Sultan Abdülaziz Dönemi çevre düzenleme çalı̧̧malarında bugünkü konumuna, caminin doğusundaki şadırvanlı avluya taşınmıştır (Fotoğraf 33). Muvakkithane ve sebil ön cephede içten oval diştan dalgalı bir şema çizerken, yan ve arka cepheleri düz hatlarla devam etmektedir (Çizim 2). Cephelerde yoğun bir Barok etkisi görülmektedir. Muvakkithane ve sebile tıpkı caminin inşa kitabesinde olduğu gibi İzzet Efendi tarih düşmüştür. Dalgalı cephede yer alan yuvarlak kemerli pencereler camide gördüğümüz sütunçelerle ayrılmış, pencerelerin üzerinde dolanan dalgalı bir friz üzerine cephenin bombeli formuna uygun olarak kitabeler yerleştirilmiştir (Fotoğraf 34). Pencereleri birbirinden ay1ran sütunçelerin başlıkları volütlü ve gilandlı bir düzenleme ile Ampir etkisi göstermektedir. Kitabe ile pencerelerin arasında kalan frizde kabara ve

17 Ayvansarayi Hüseyin Efendi, Hadîkat'ül Cevâmi, (2. Bölüm), İstanbul, H. 1281 s. 64. “ ...mahfil-i hûmayun minber tarafinda olup kafesi yekpare pirincden oyma ve yaldızlıdır.” şeklinde aktarılmaktadır. girlandlar birbiri ardına kullanılarak bir süreklilik sağlanmıştır. Süsleme detayları ve plan şeması itibariyle birbirini tekrarlayan sebil ve muvakkithane pencerelerinin demir şebekeleri altın varaklıdır. Her iki yapıya da sade düzenlemesiyle ahşap kanatlı kapılardan girilir. Külahla örtülü muvakkithane ve sebilde hafif dışa taşkın basit profilli bir saçak görülmektedir. Sebilin arka cephesinde bir dizi çeşme yer alır. Çeşmelerin aynalıkları dikdörtgen şemada olup sövelerinin birleşme köşeleri belirtilmiştir fakat günümüzde çeşmeler aktif değildir (Fotoğraf 35).

Yeterli alan olmadığından şadırvan caminin doğu tarafinda yapılmıştır (Fotoğraf 36). Avlu zemininden yaklaşı 10 santimlik bir platformla yükseltilmiştir. D1ştan sivri bir külah, içten yayvan bir kubbe ile örtülüdür. 10 adet daire kesitli sütun tarafindan taşınan sivri külah muvakkithane ve sebilin külahıyla benzerdir. Sütun gövdeleri daire kesitli olmasına karşın kaideler kare kesit arz etmektedir. Mermer havuz on iki kenarlıdır ve bir kaidesi mevcuttur. Bu sütunların yuvarlak başlıkları üzerine gayet sade ve yüzeysel olarak altı kollu yıldızlar işlenmiştir. Tezyini bir öge bulundurmayan mermer havuzda aynaliklar belirtilmemiştir. 1850-55 yıllarına ait olduğu tahmin edilen fotoğraflarda şadırvan külahında yapıda kullanılan diğer alemlerden farklı, günümüze gelmeyen 1̧̧ınsal şemada bir alemin olduğunu görüyoruz. Bu alemin külahla birleşme kısımları akantus yapraklarıyla süslenmiştir (Fotoğraf 37). Buna benzer bir alem bugün II. Mahmud'un türbesinin kubbesinde de görülmektedir. Aynı fotoğrafta külahın saçaklarının hemen altında friz şeklinde bir duvar resmi panoramik olarak şadırvanı dolanmaktadır. Osmanlı mimarisinde şadırvanların resimle süslenmesi nadir ve önemli hadiselerdir. Bu duvar resmi fotoğraftan okunabildiği kadarıyla içinde mimari ögeler bulunan bir manzara temasina sahipti fakat maalesef günümüze ulaşamamıştır.

II. Abdülhamid Dönemi'nde caminin önüne yapılan ve caminin estetik hüviyetine uygun bir 
şekilde tasarlanmış, Barok ve Ampir üsluptaki çeşme 1897 tarihli olup "Hamidiye Çeşmesi" olarak anılmıştır ${ }^{18}$ (Fotoğraf 38). Çeşmede kademeli ve eklektik bir örtü sistemi dikkati çekmektedir. Burada en tepede küçük boyutlu bir soğan kubbe ile aynalı tonozun birleşiminden meydana gelen farklı bir uygulama görülmektedir. II. Abdülhamid dönemine kadar bu tarz bir uygulama görülmemesinden yola çıkarak bu dönemde Payitaht'ta yaygin olan Oryantalist üslubun bir etkisi olduğu düşünülebilir (Fotoğraf 39). Geniş saçakları ve hareketli süsleme programıyla çeşme, plan itibariyle dikdörtgen bir şemayı ihtiva etmekte ve dört cephesinde çeşme bulunmaktadır. Profilli silmelerle hareketlendirilmiş ön ve arka cephede oluk silmeli geniş bir niş oluşturulmuştur. Nişin içi boşaltılarak bir açıklık meydana getirilmiş, açıklık üst köşelerde volütlü konsollarla desteklenmiştir. Dört köşede kare kesitli ve dairevi başlıkları olan daire kesitli sütunçeler dönemin özelliğini yansıtmaktadır. Burada kaidelerde akantus yapraklı düzenlemeler ve sütun başlıklarında akantus yapraklarının kıvrılmasıyla oluşan volütler arasında gerilmiş girlandlar Ampir etkiler göstermektedir. Dört cephede kitabeler mermer üzerine mahkuk olup ilk haliyle koyu zemin üzerine altın varaklı olduğu eski fotoğraflardan anlaşılmaktadır. Tüm kitabeler "c" kıvrıml1-volütlü bitki dalları ve yapraklarla tezyin edilen kartuşların içinde yer almaktadır. Kitabelerin bulunduğu yüzey tüm cephelerde çökertilmiş olup iki yanında "s" kıvrımlı akantus yaprakları görülmektedir. Cephedeki açıklık metal şebekelerle adeta bir dantel gibi işlenmiştir. Bu metal şebekenin merkezinde yer alan daire biçimli kasnakta, bir zamanlar Sultan II. Abdülhamid'in tuğrasının olduğu eski fotoğraflardan anlaşılmakla birlikte günümüze bu tuğra yerinde bulunmamaktadır (Fotoğraf 39). Taç kısmı "s" kıvrımlı dallar ve akantus yapraklarryla düzenlenmiştir ve orta-

18 M. Burak Çetintaş, Dolmabahçe'den Nişantaşı'na, İstanbul, 2005, s. 152

- Hamidiye Çeşmesi için bir başka tarih Tahsin Öz tarafindan "1901" olarak aktarılmaktadır. Bkz. Tahsin Öz, İstanbul Camileri, Ankara, 1997, s. 30. sinda; aslında köken itibariyle Doğu'dan gelen fakat uygulama biçemi olarak Barok etkili meyve küfesi ve içinde çeşitli meyveler görülmektedir. Aynalık iki yanda kare kesitli sütunçelerle çerçevelenmiş ve Oryantalist ektili bir kemer ile hareketlendirilmiştir. Bu kısmının iki yanında süsleme unsuru olarak kullanılan küçük nişler Hamidiye Türbesi’nin cephesinde gördüğümüz çeşmelerin adeta birer minyatürü niteliğindedir ve daha çok Rokoko üslubunda gördüğümüz bir uygulama olarak karşımıza çıkmaktadır. Bu durum dönemin beğenisinin farklı eserlerde karşımıza çıkması konusunda güzel bir örnek teşkil eder. Arka cephede ön cephedeki çeşme düzenlemesinin simetriği olması gerekirken bu kısım bugün boştur. Fakat bu cephede yer alan tahrip olmuş tekneden anlaşıldığına göre burada da ön cephedeki gibi bir çeşme düzenlemesi olmalıydı. Çeşme istimlak çalışmaları neticesinde yerinden sökülüp Maçka’ya taşınmıştır. Genel hatlarıyla Barok ve Oryantalist etkilerin ağırlıkta olduğu çeşmede yer yer Ampir etkileri görülmektedir. Günümüzde ciddi hasara uğramı̧̧ olan çeşme Osmanlı Son Dönem çeşmeleri arasında farklı ve önemli bir örnektir.

Nusretiye Camii Geç Barok ve Ampir üsluplarının mimari ve süslemede kullanıldığı önemli bir örnektir. Yapının tezyinat programına baktığımızda; zamanla değişmesi zor olan taş tezyinat büyük oranda özgünlüğünü ve tarihselliğini muhafaza ederken, kalem işi tezyinat için ne yazık ki aynısını söylemek mümkün değildir. Bir sanat eserini yapıldığı dönemin politik ve ses getiren olaylarıyla bağdaştırmak her zaman tutarlı bir sanat tarihi sistematiği olmayabilir. Dolayısıyla Nusretiye Camii'nin adı ile "zafer" yakıştırması; işte böyle bir durumda gerek anlamsal gerekse pratik açıdan tutarsızlık göstermektedir. Sultan II. Mahmud Dönemi’nin politik arayı̧̧ ya da anlayışları her ne olursa olsun Nusretiye'nin bir ibadet mekanı olduğu gerçeğini aklımızdan çıkarmadan algılamak ve bu minvalde yorumlamak gerektiğini düşünmekteyiz. 


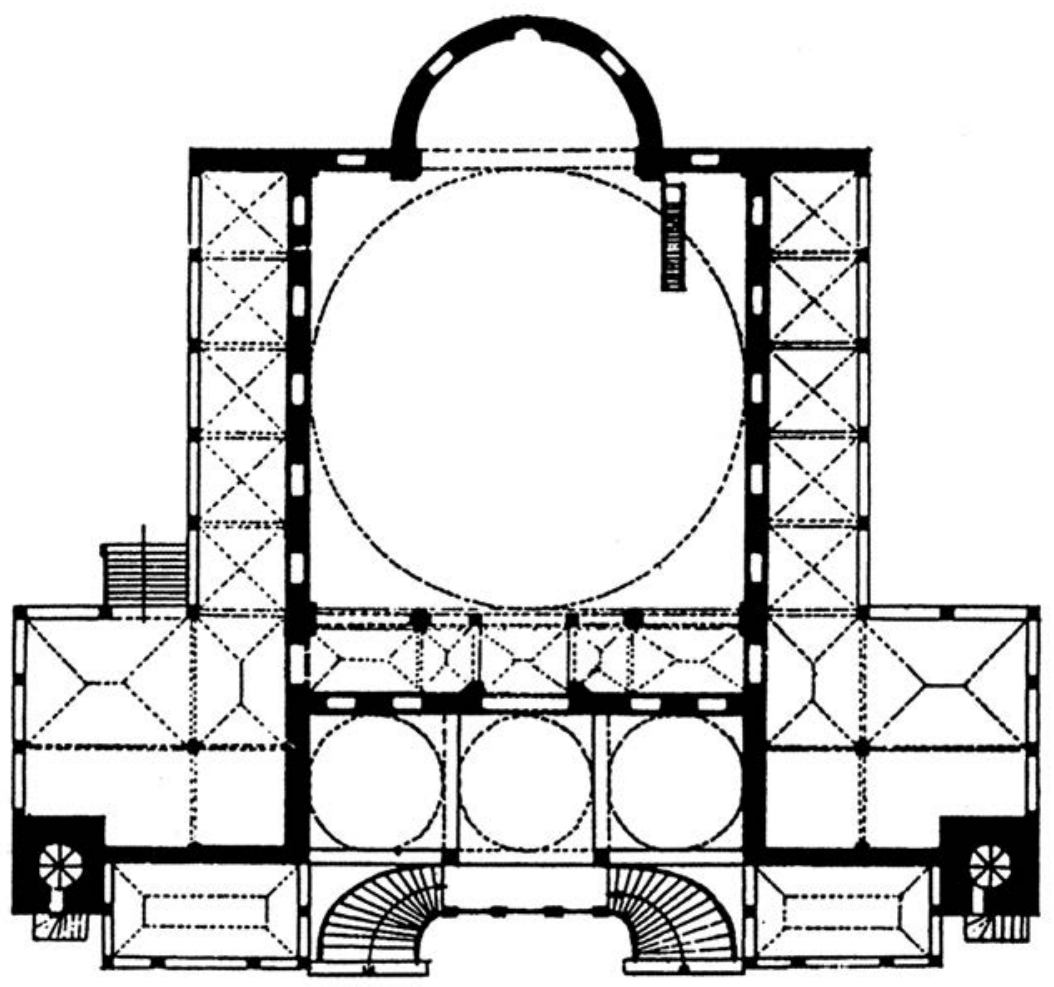

Çizim 1: Nusretiye Camii planı (Aslanapa).

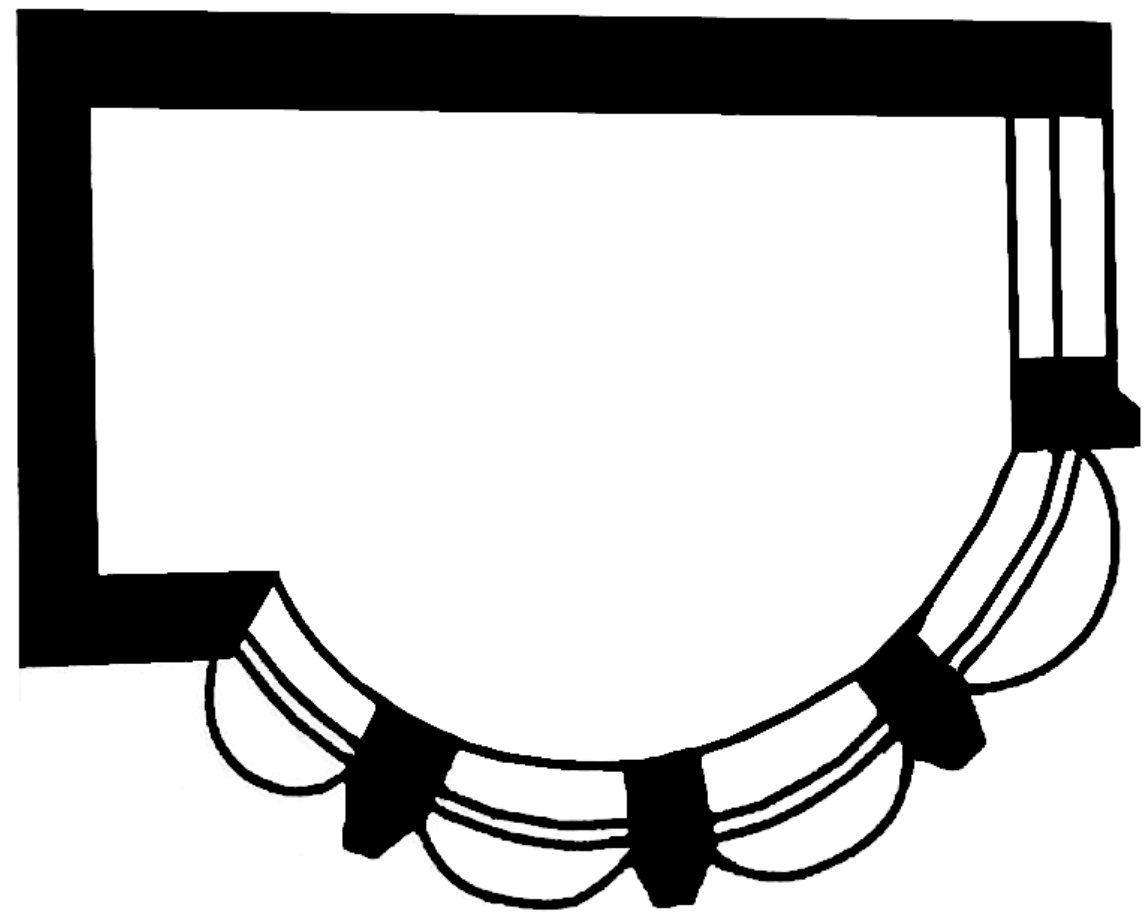

Çizim 2: Nusretiye Camii sebili planı (Ş̧erifoğlu). 


\section{Dursun ARSLAN}

TARIHSEL KONUMU Ve MIMARISIYLE NUSRETIYE CAMII

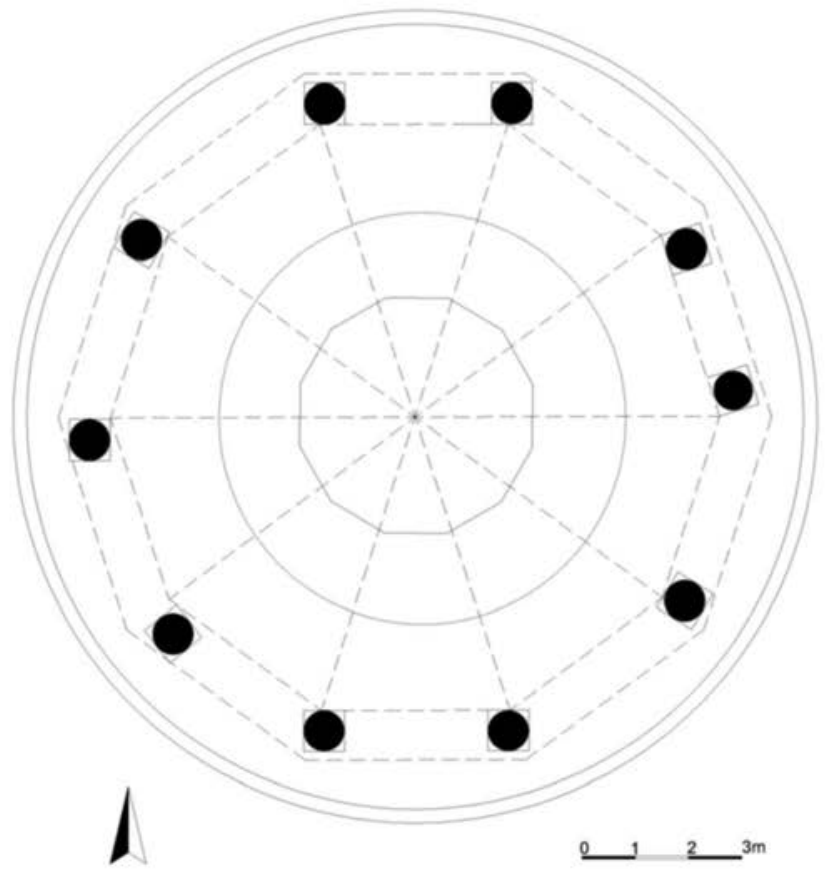

Çizim 3: Nusretiye Camii şadırvan planı (Tali).

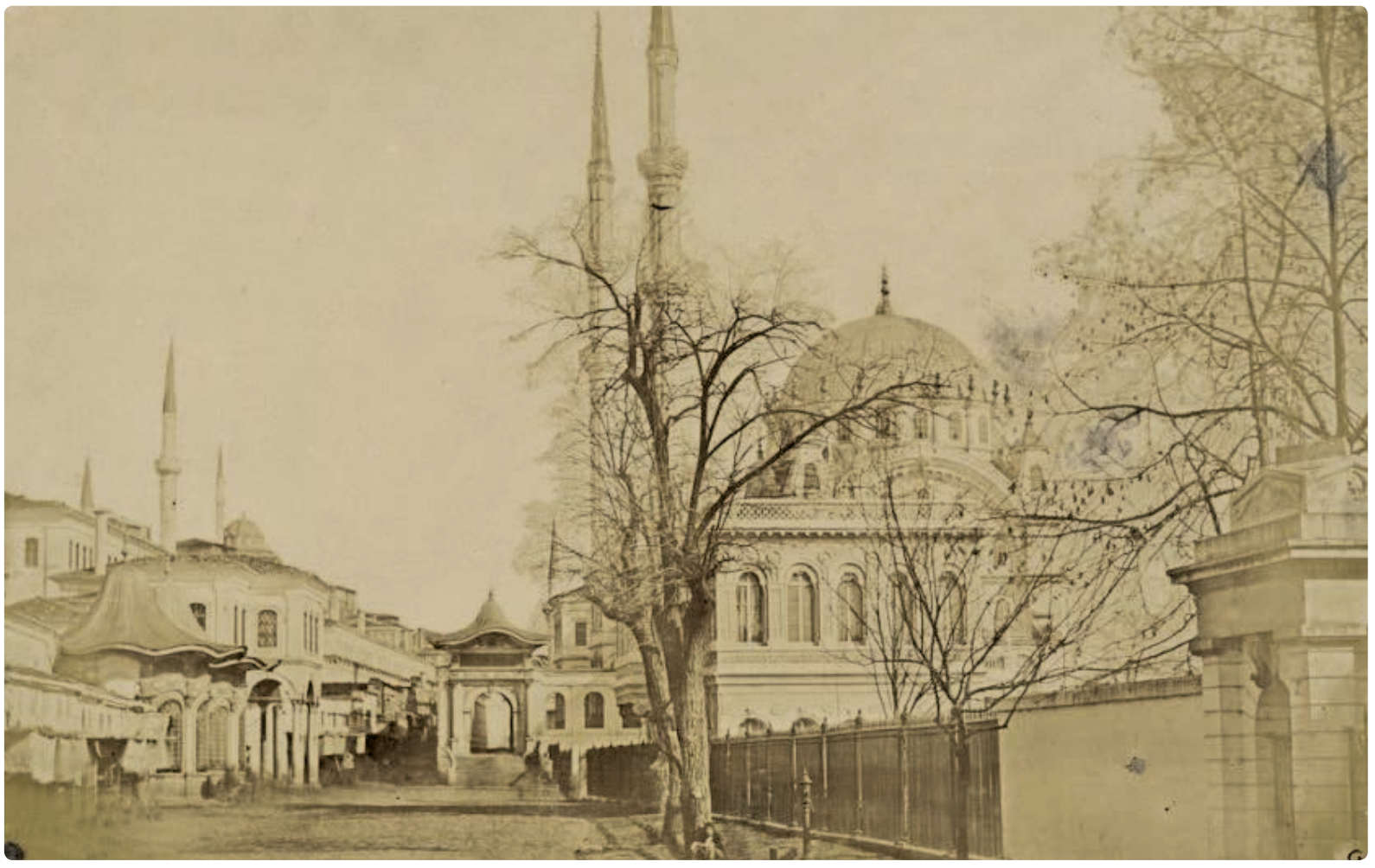

Fotoğraf 1: Nusretiye Camii’nin ilk halini gösteren bir fotoğraf. (1850-1855) 


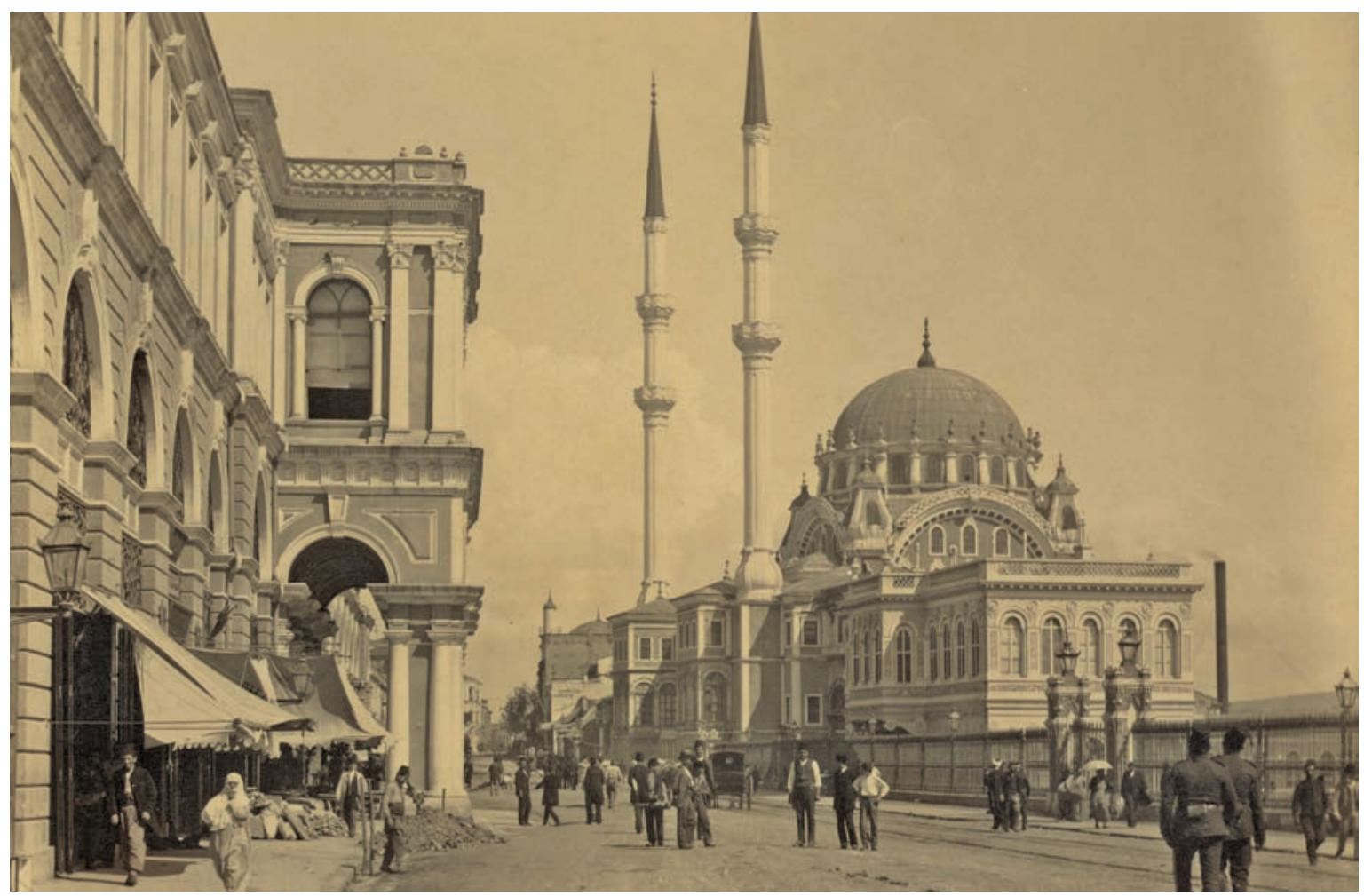

Fotoğraf 2: Sultan Abdülaziz (1861 -1876) dönemi çevre düzenleme çalışmaları sonrası.

(Sebah E Joaillier, 1880-1900, Library of Congress Photographs Archive)

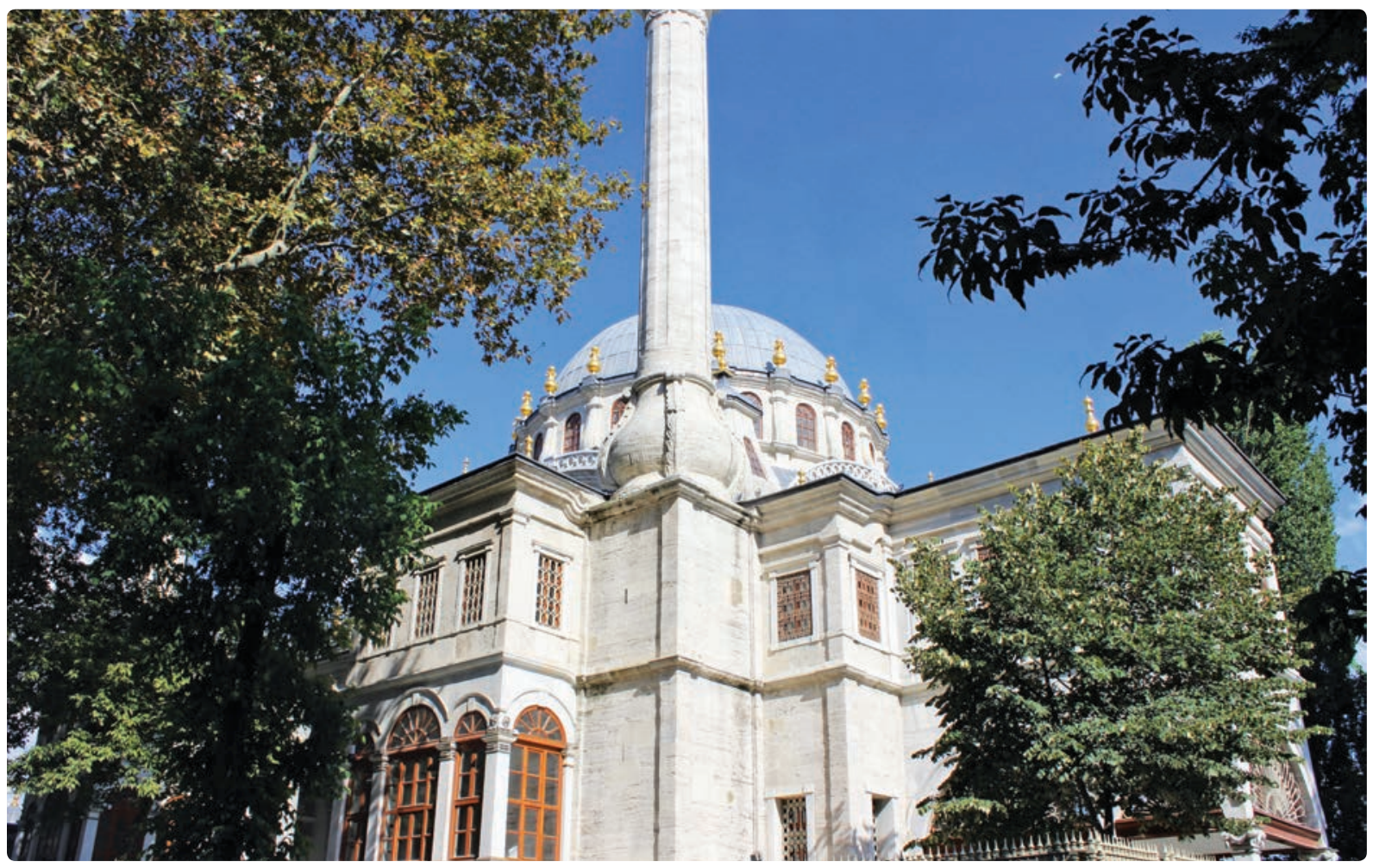

Fotoğraf 3: Kuzey cepheye bakı̧̧. 


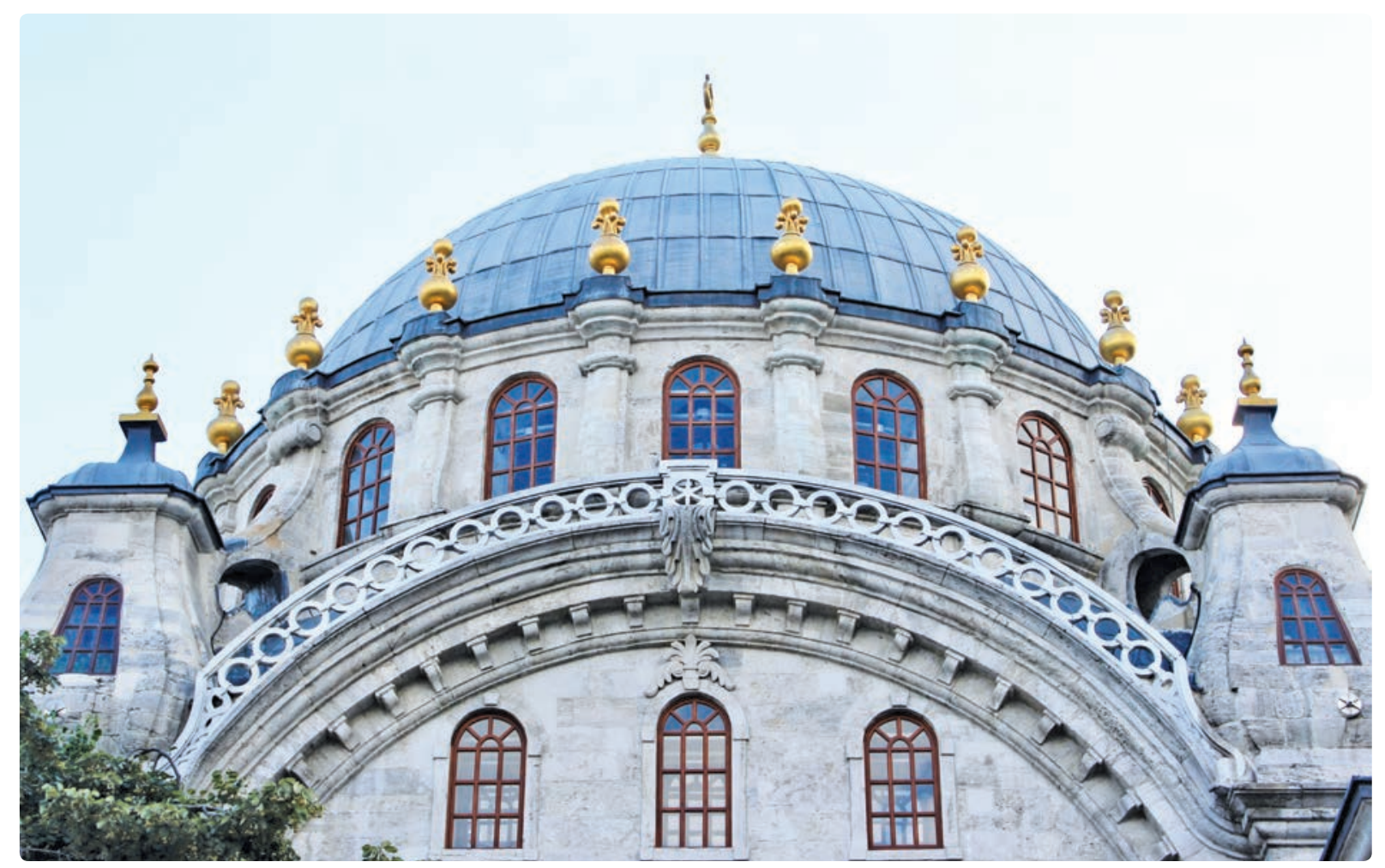

Fotoğraf 4: Bektași (ă̆ırlık) kuleleri ve kuleleri kubbe kasnağına bağlayan payandalar.

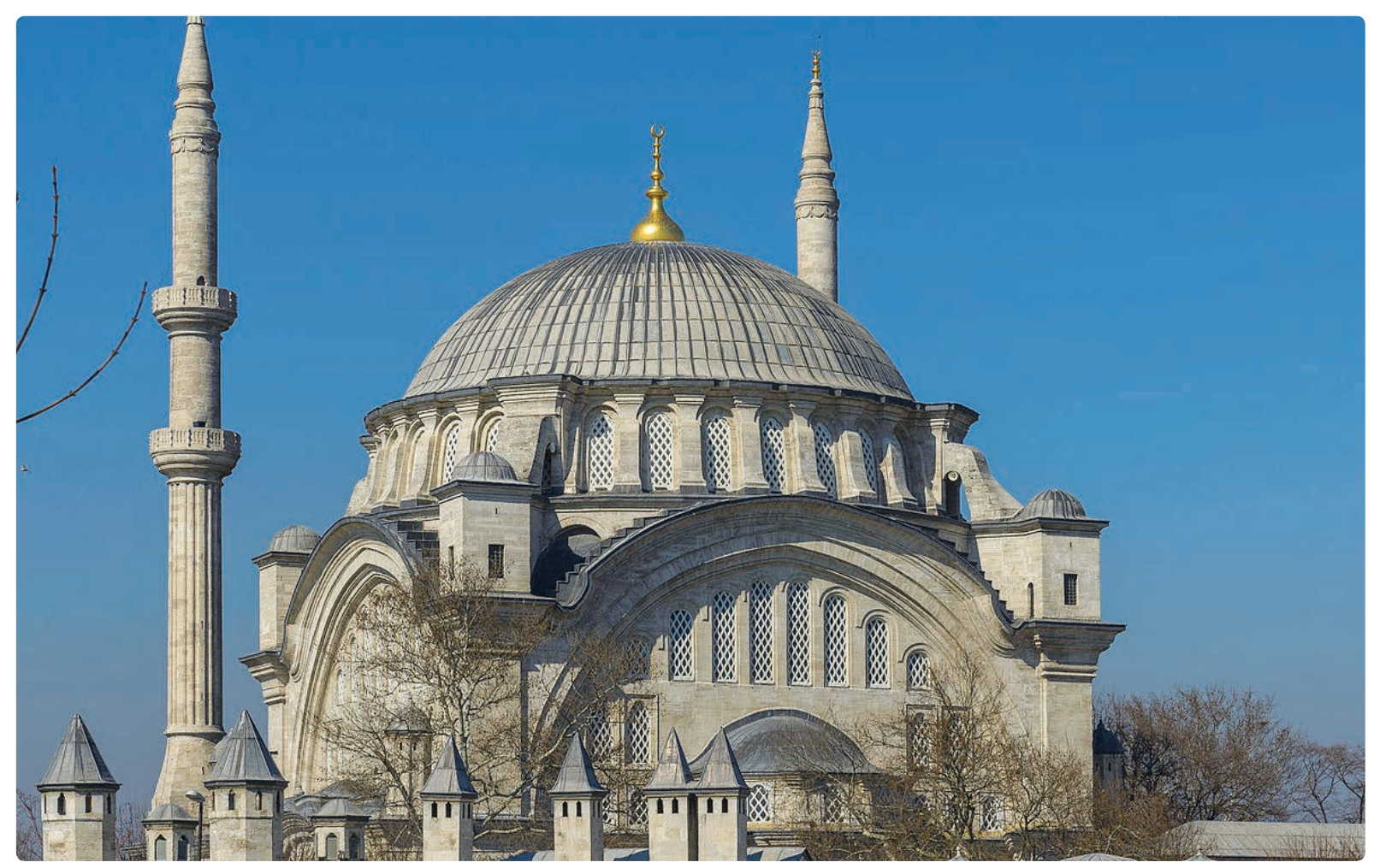

Fotoğraf 5: Nuruosmaniye Camii ve kubbeyi tașıyan kemerlerin kademeli silmeleri. 


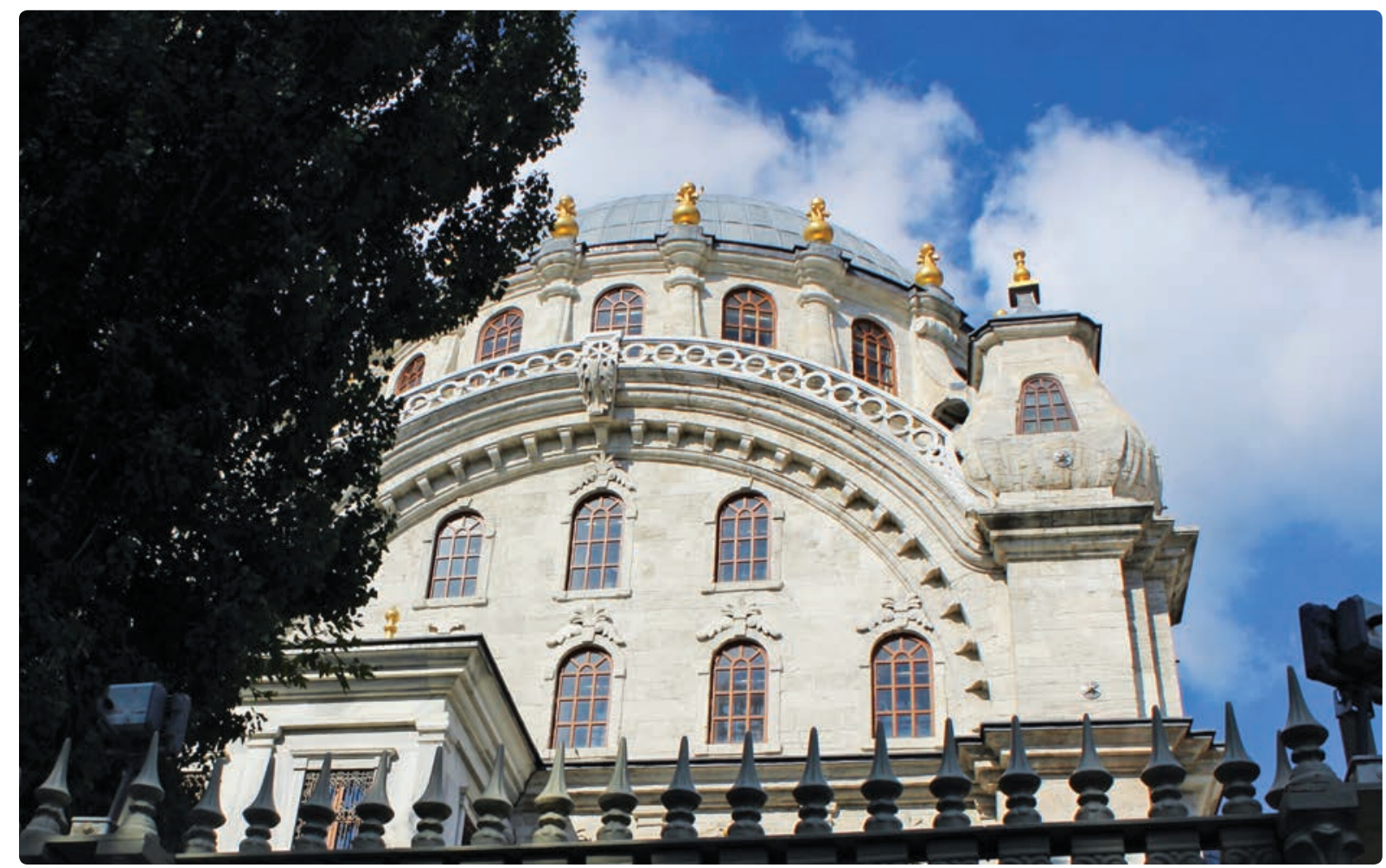

Fotoğraf 6: Batı cephesinden pencere düzenini gösteren fotoğraf.

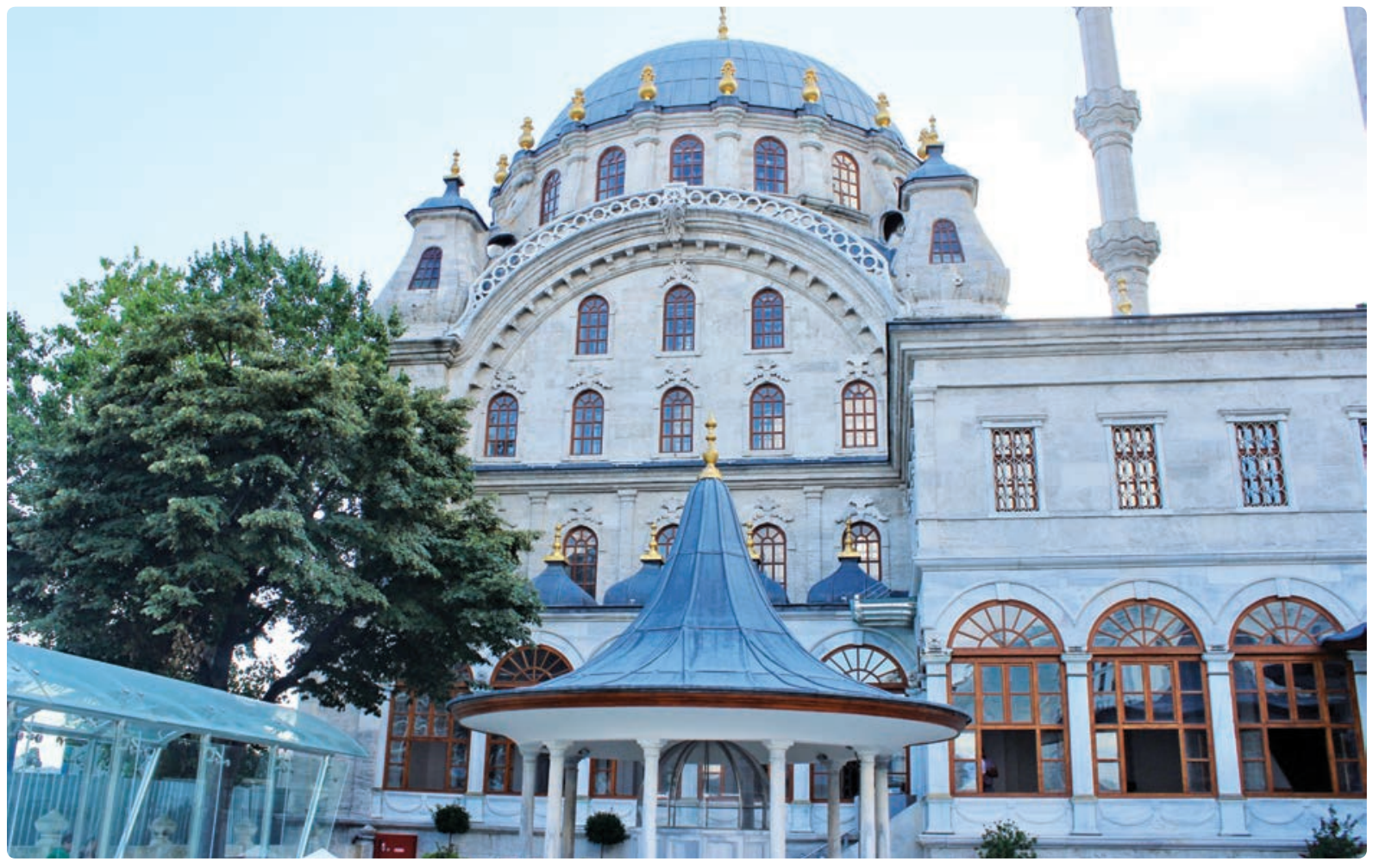

Fotoğraf 7: Nusretiye Camii Doğu cephesinden görünüm. 
TARIHSEL KONUMU Ve MIMARISIYLE NUSRETIYE CAMII

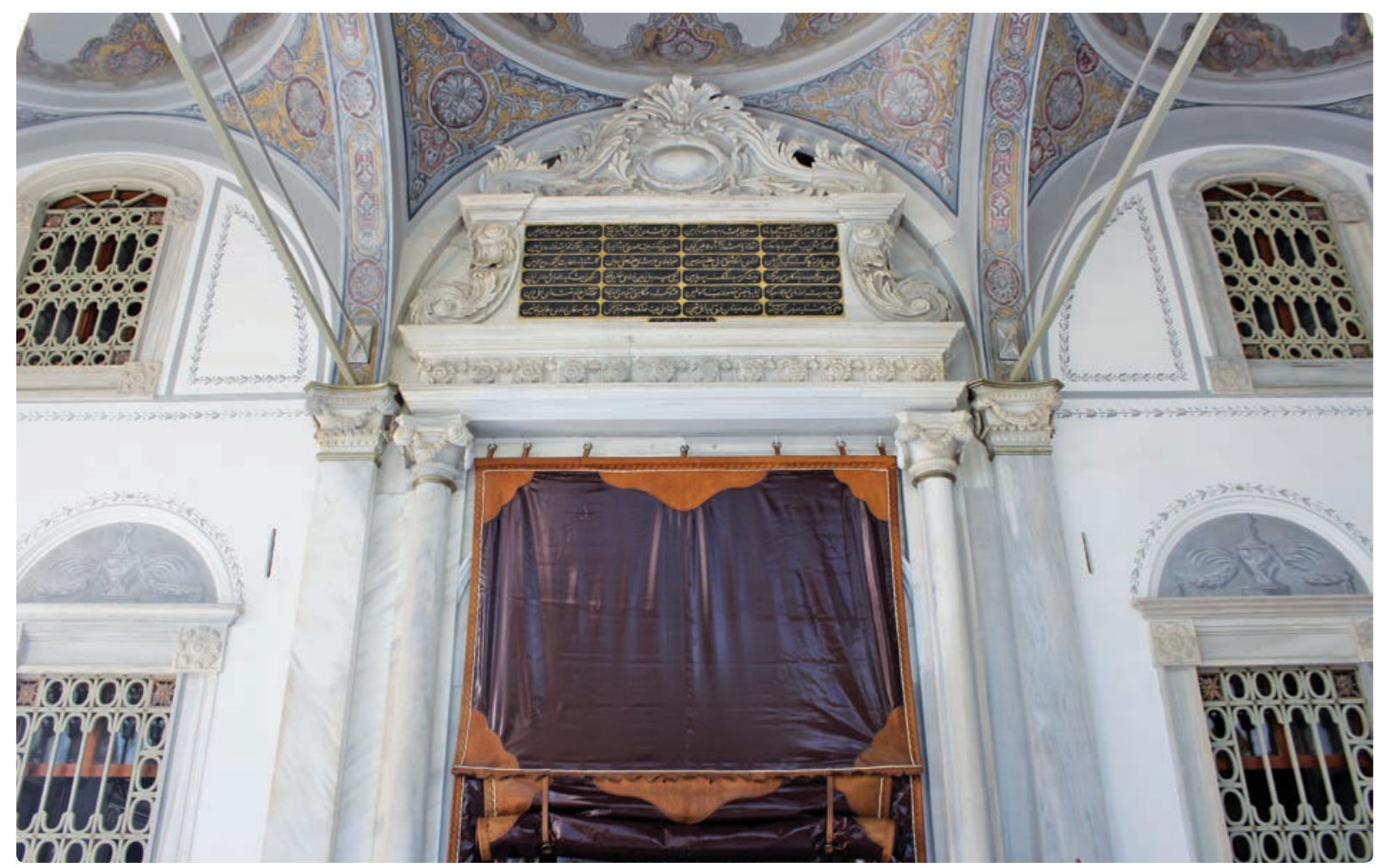

Fotoğraf 8: Nusretiye Camii cümle kapısı

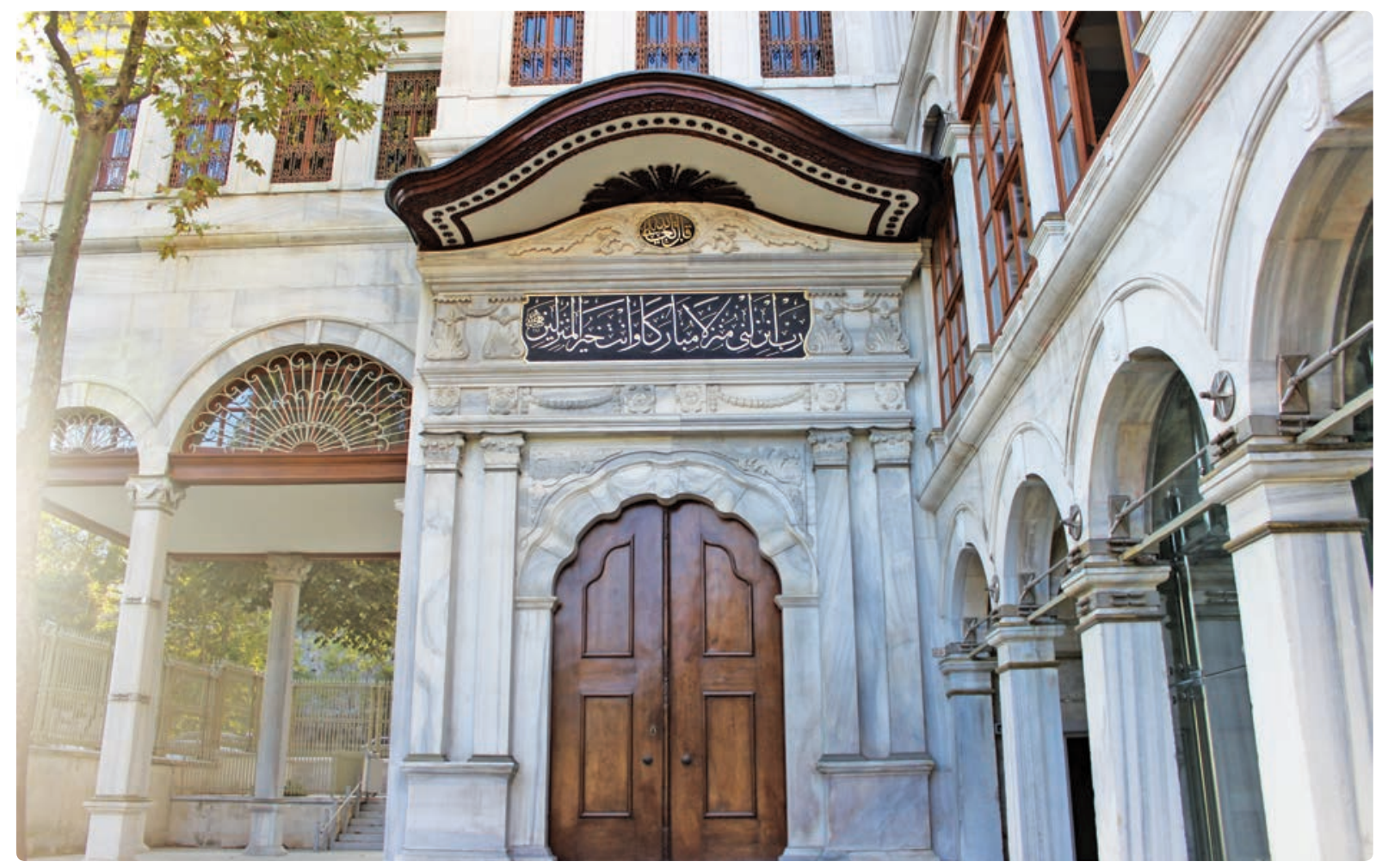

Fotoğraf 9: Nusretiye Camii bünkar kapısı. 
Dursun ARSLAN

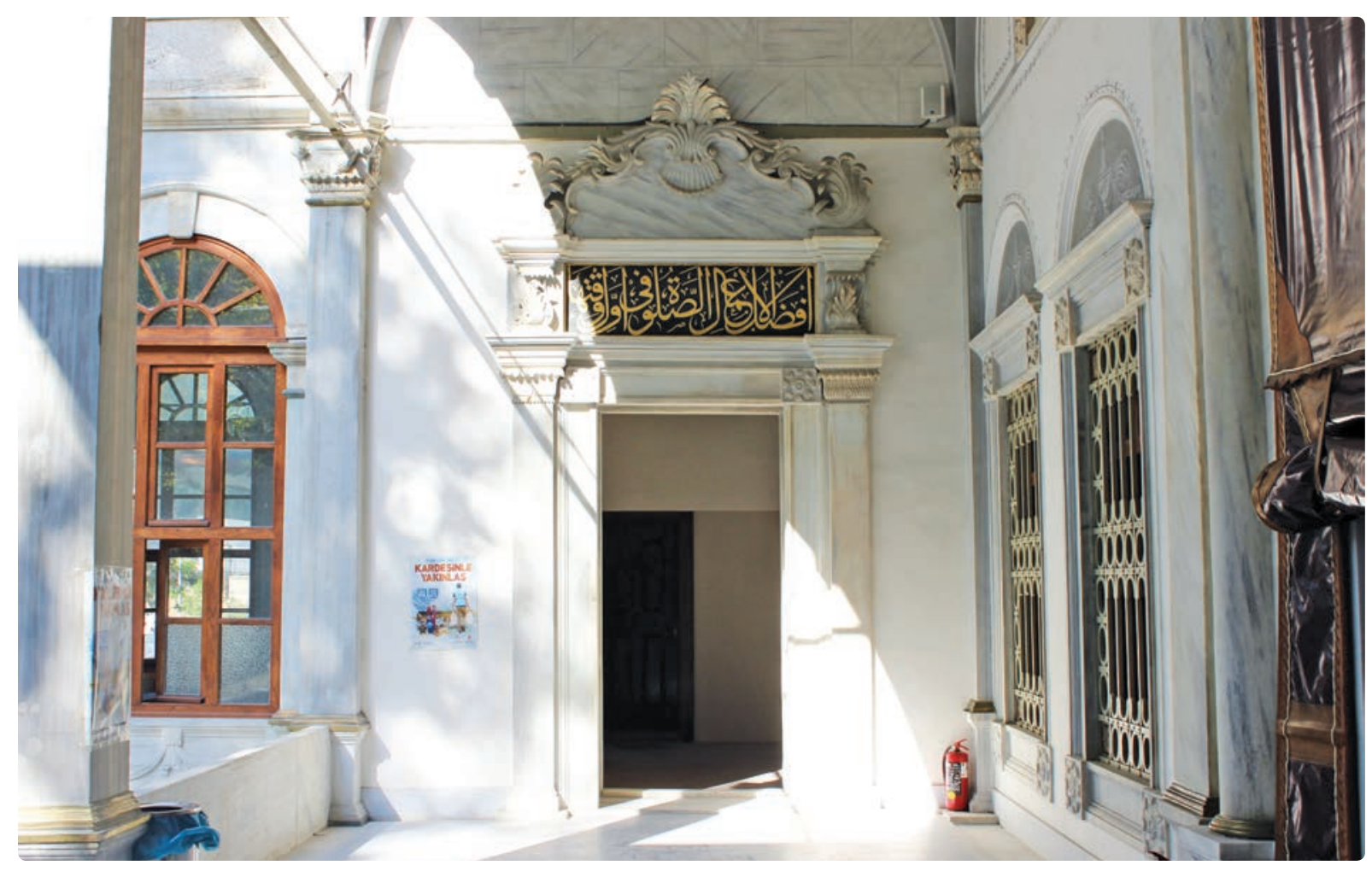

Fotoğraf 10: Yan sofalara geçis kapıları.

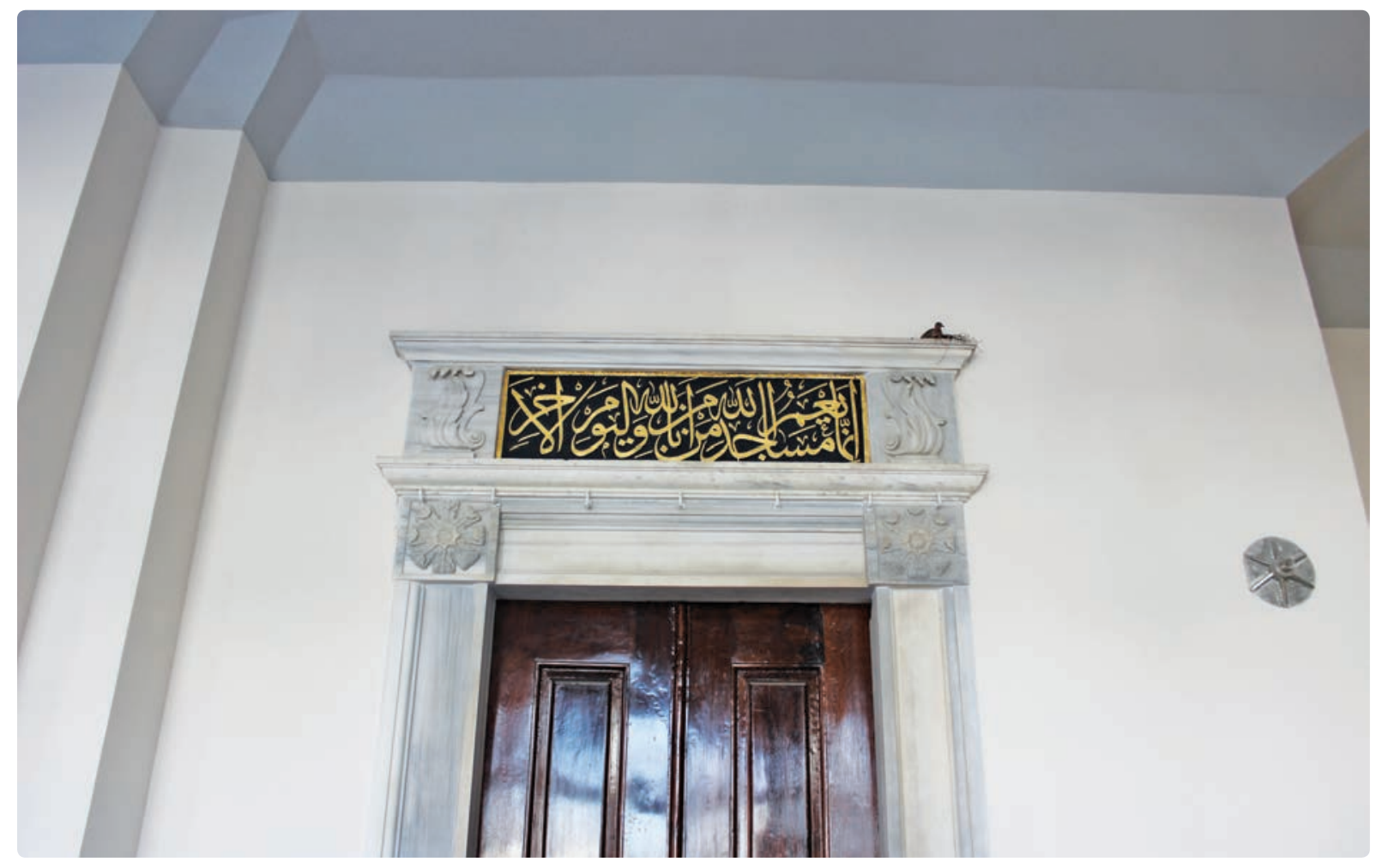

Fotoğraf 11: Yan sofalardan hareme geçilen kapi. 


\section{Dursun ARSLAN}

TARIHSEL KONUMU Ve MIMARISIYLE NUSRETIYE CAMII

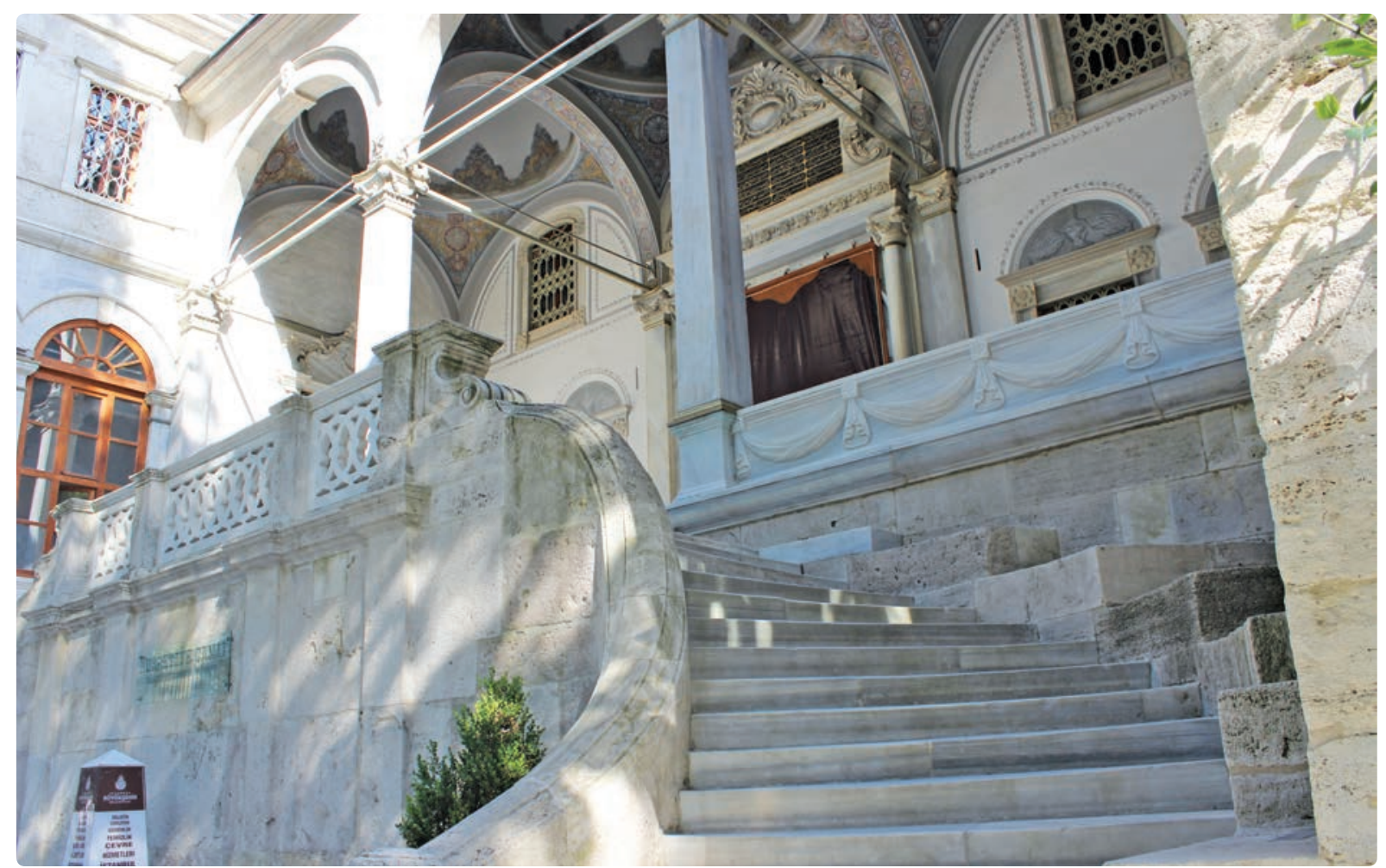

Fotoğraf 12: Kuzey cephede merdivenler.

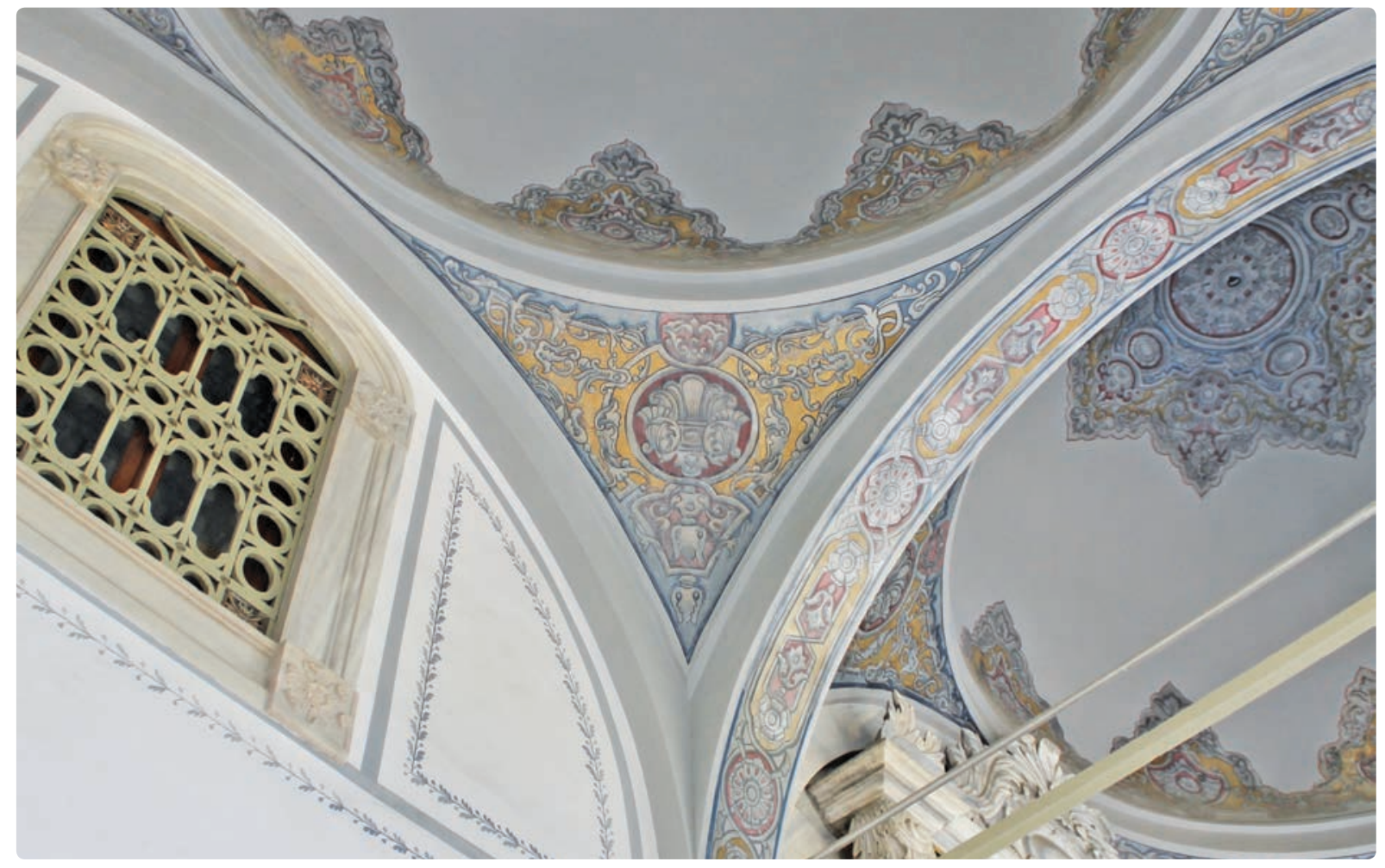

Fotoğraf 13: Girişsofasinda görülen kalem işleri. 
Dursun ARSLAN

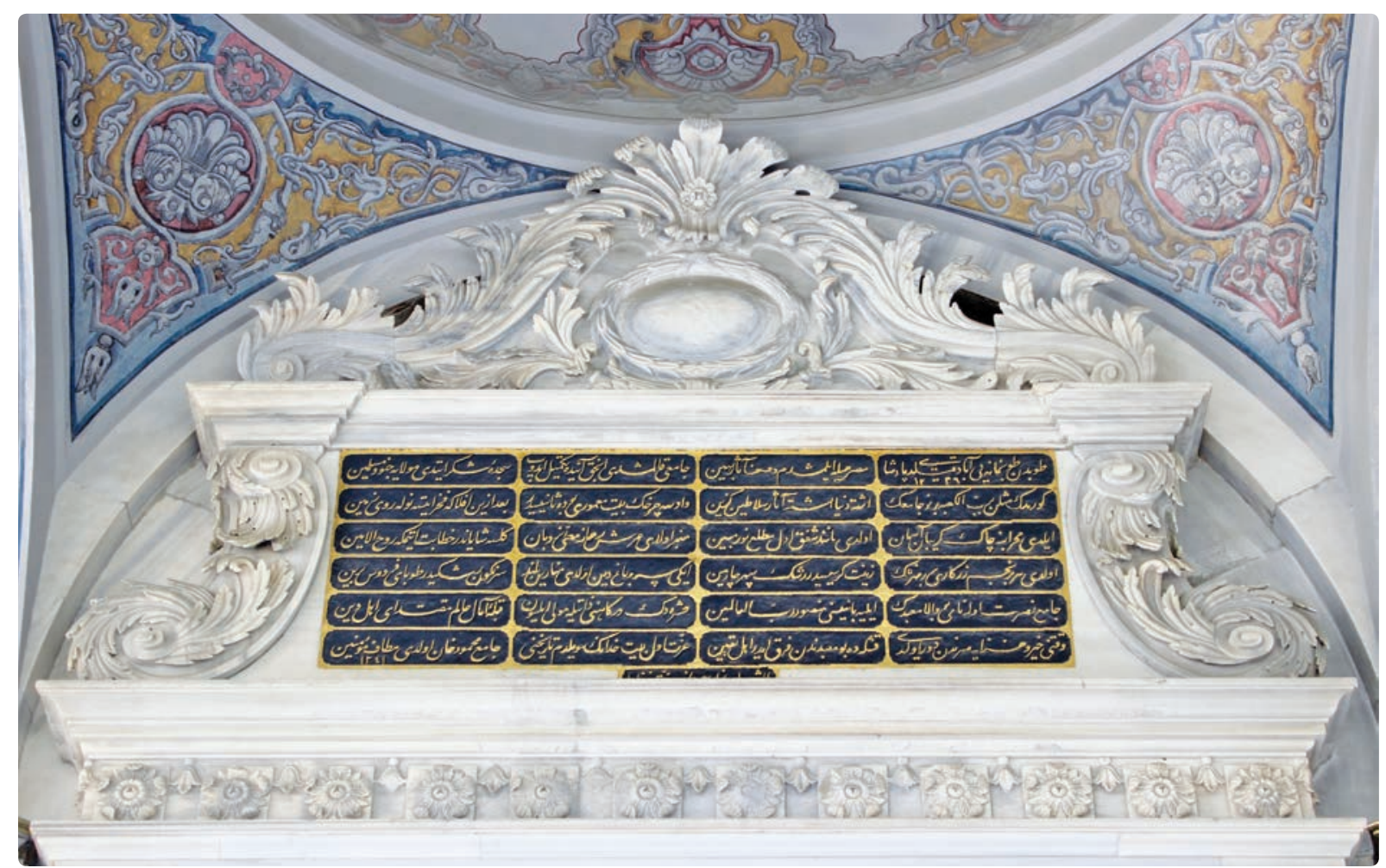

Fotoğraf 14: İnşa kitabesi ve cümle kapısından detay.

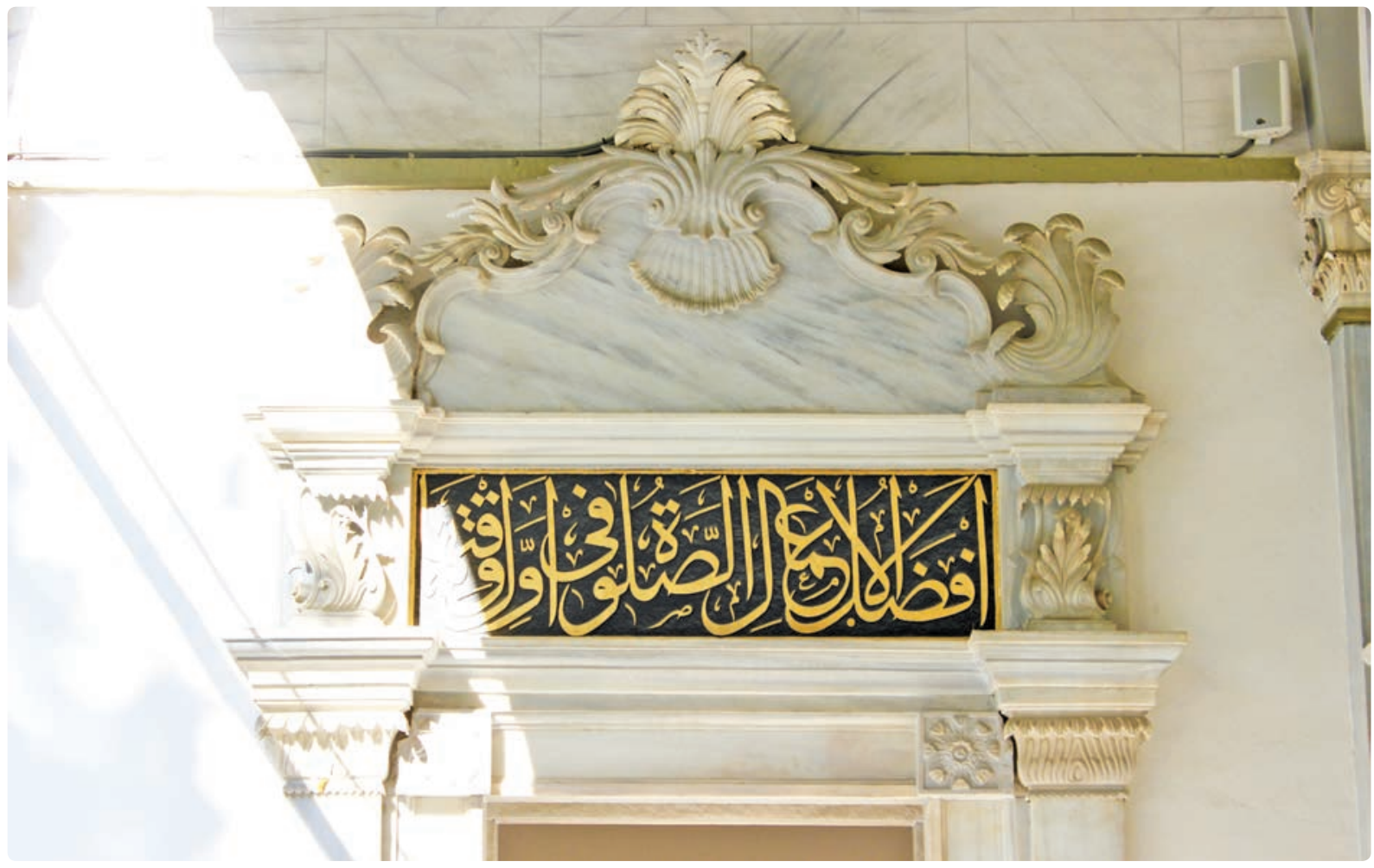

Fotoğraf 15: Doğu sofasına geçiş kapısı kitabesi. 


\section{Dursun ARSLAN}

TARIHSEL KONUMU Ve MIMARISIYLE NUSRETIYE CAMII

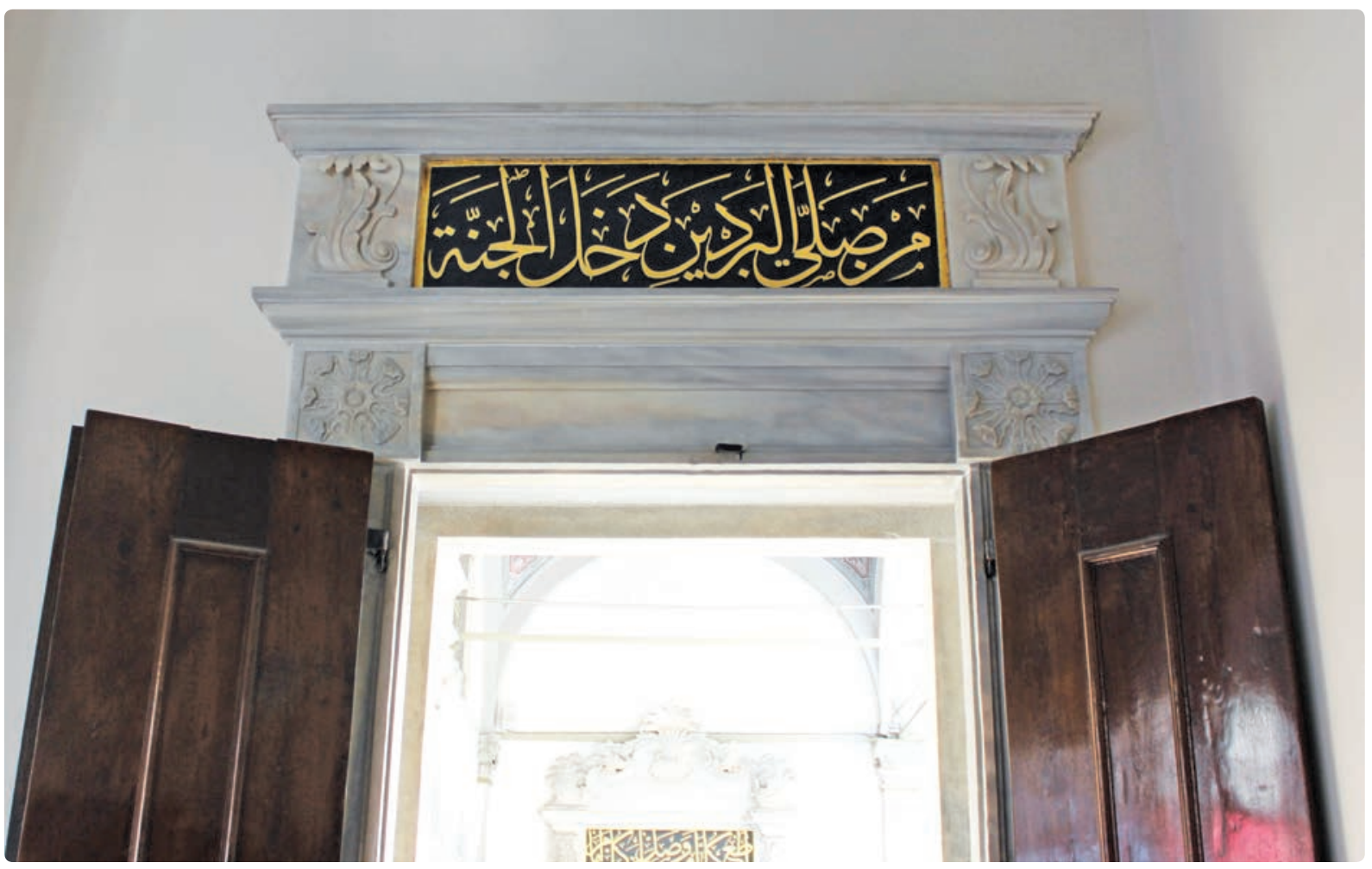

Fotoğraf 16: Doğu sofasına geçiş kapısının iç yüzündeki kitabe.

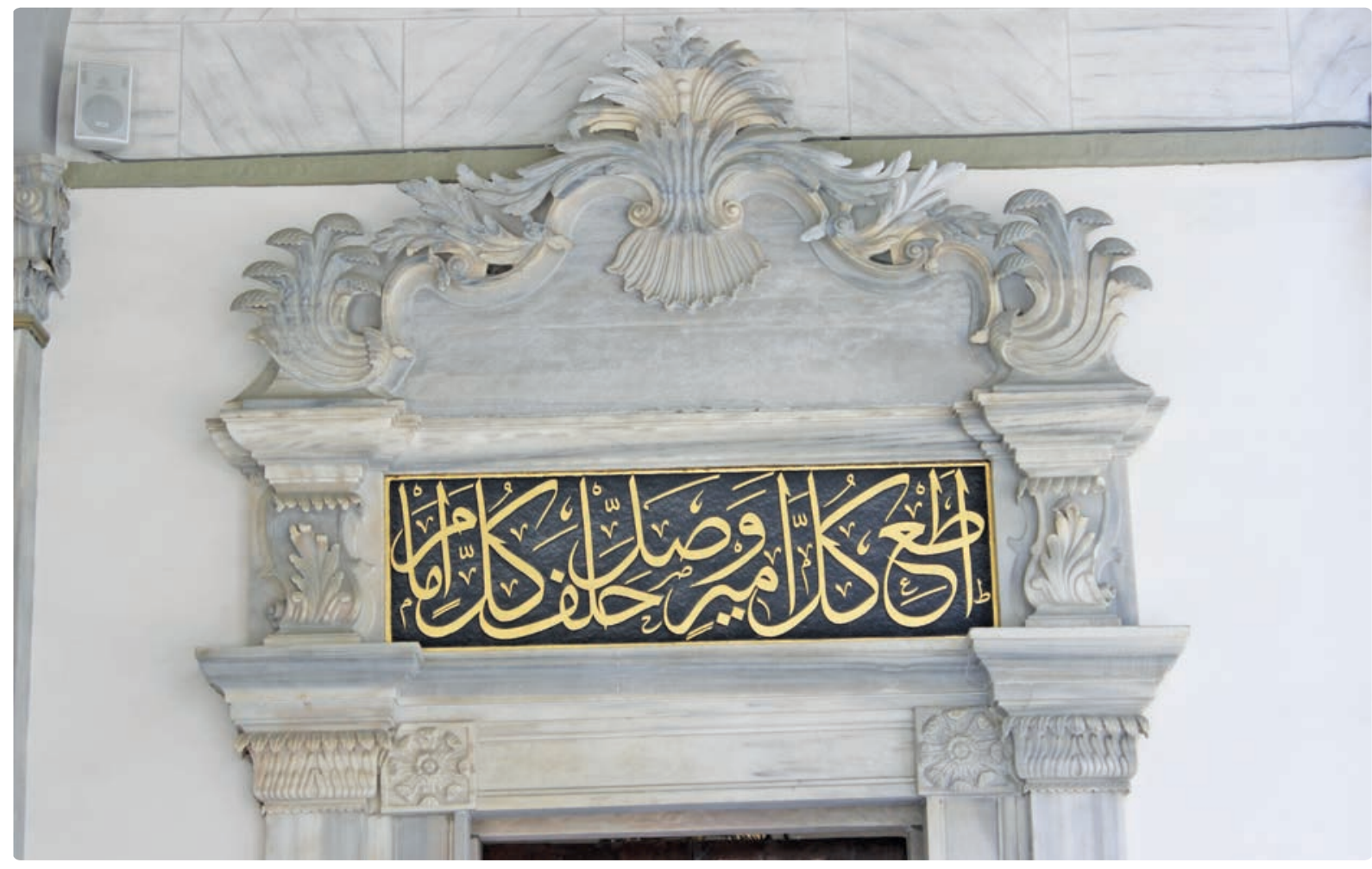

Fotoğraf 17: Batı sofasına geçis kapısı kitabesi. 
Dursun ARSLAN

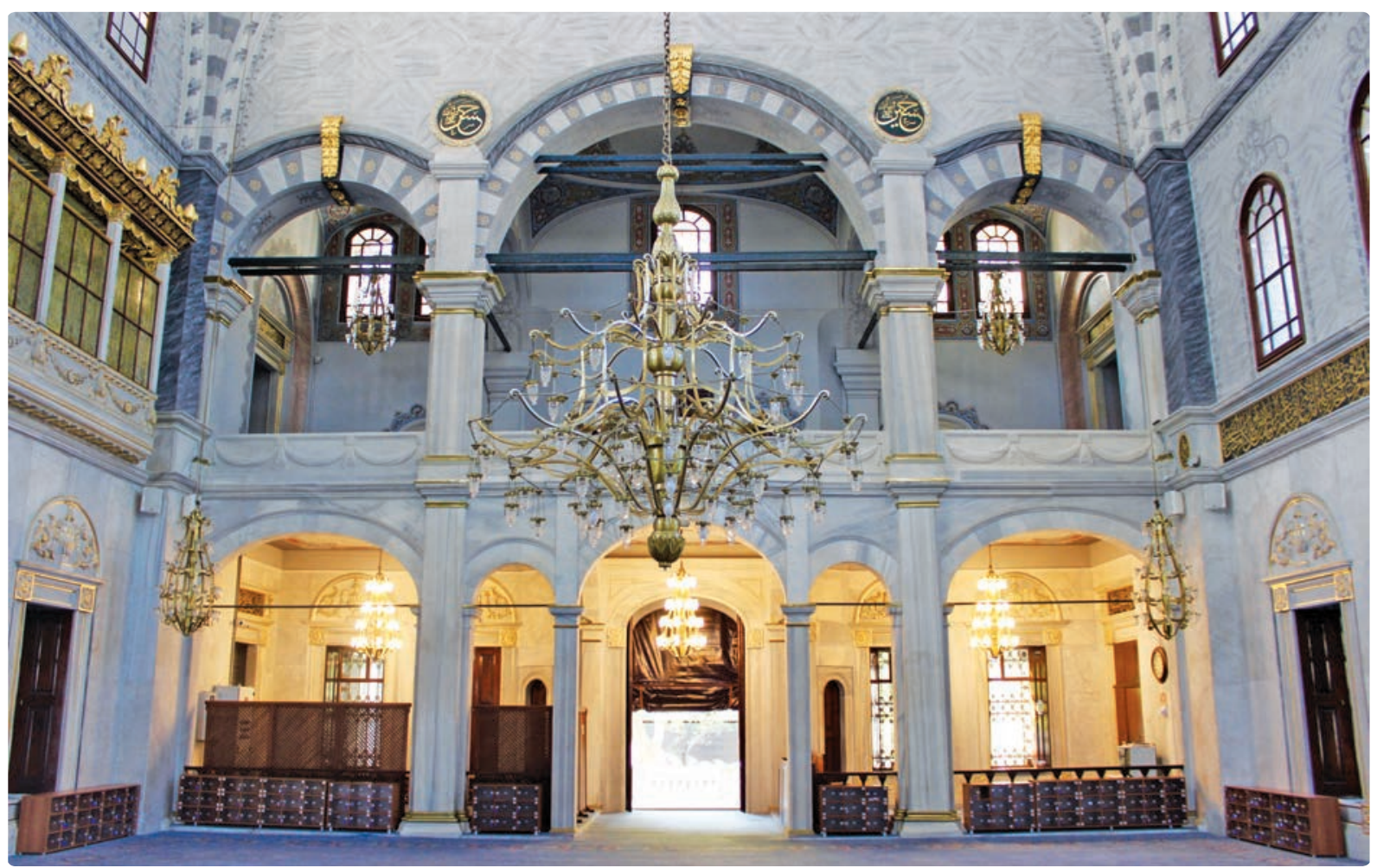

Fotoğraf 18: Harem kıble duvarından görünüm.

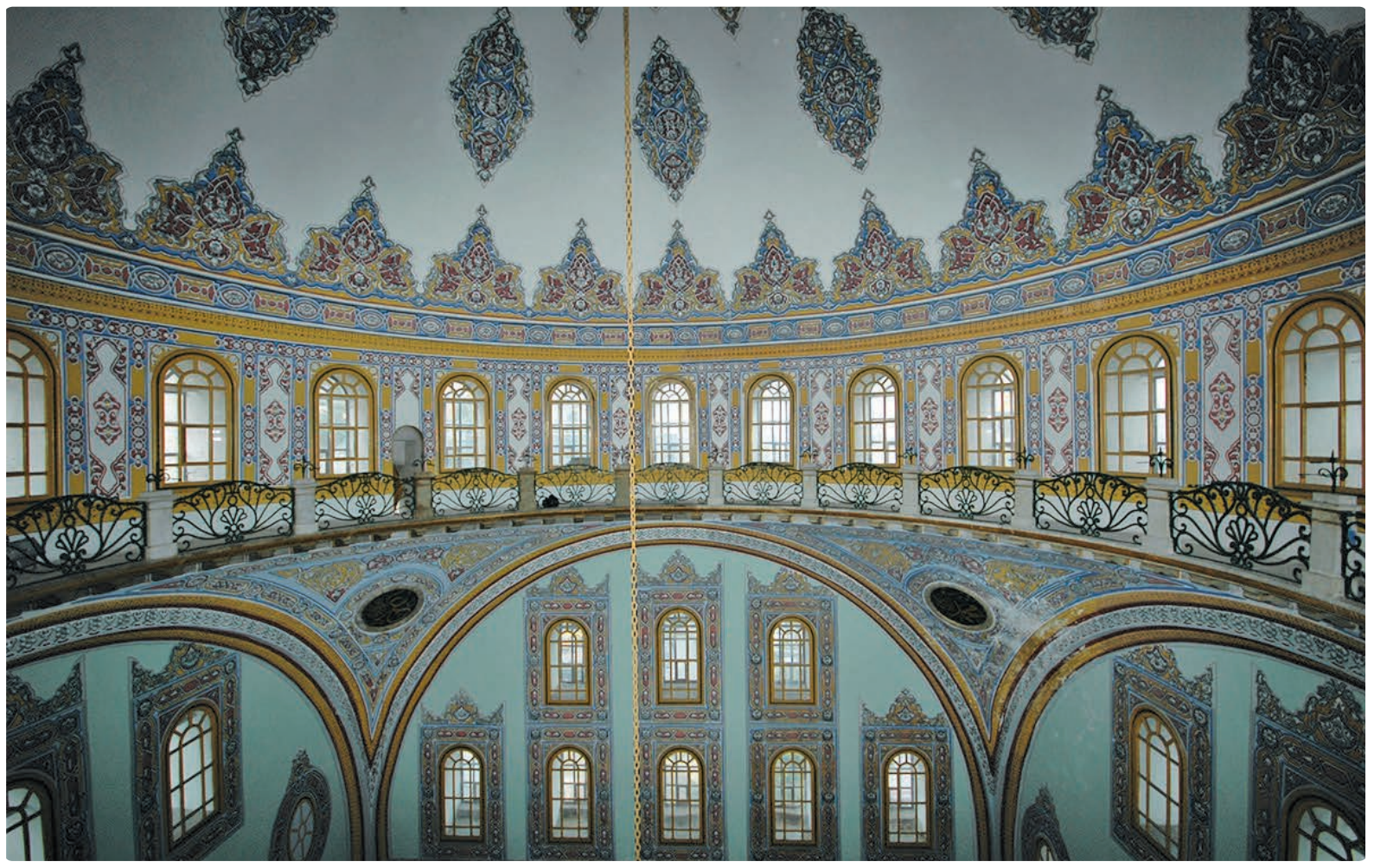

Fotoğraf 19: Harem kalem işi programı 2018 onarımları öncesi. 
TARIHSEL KONUMU Ve MIMARISIYLE NUSRETIYE CAMII

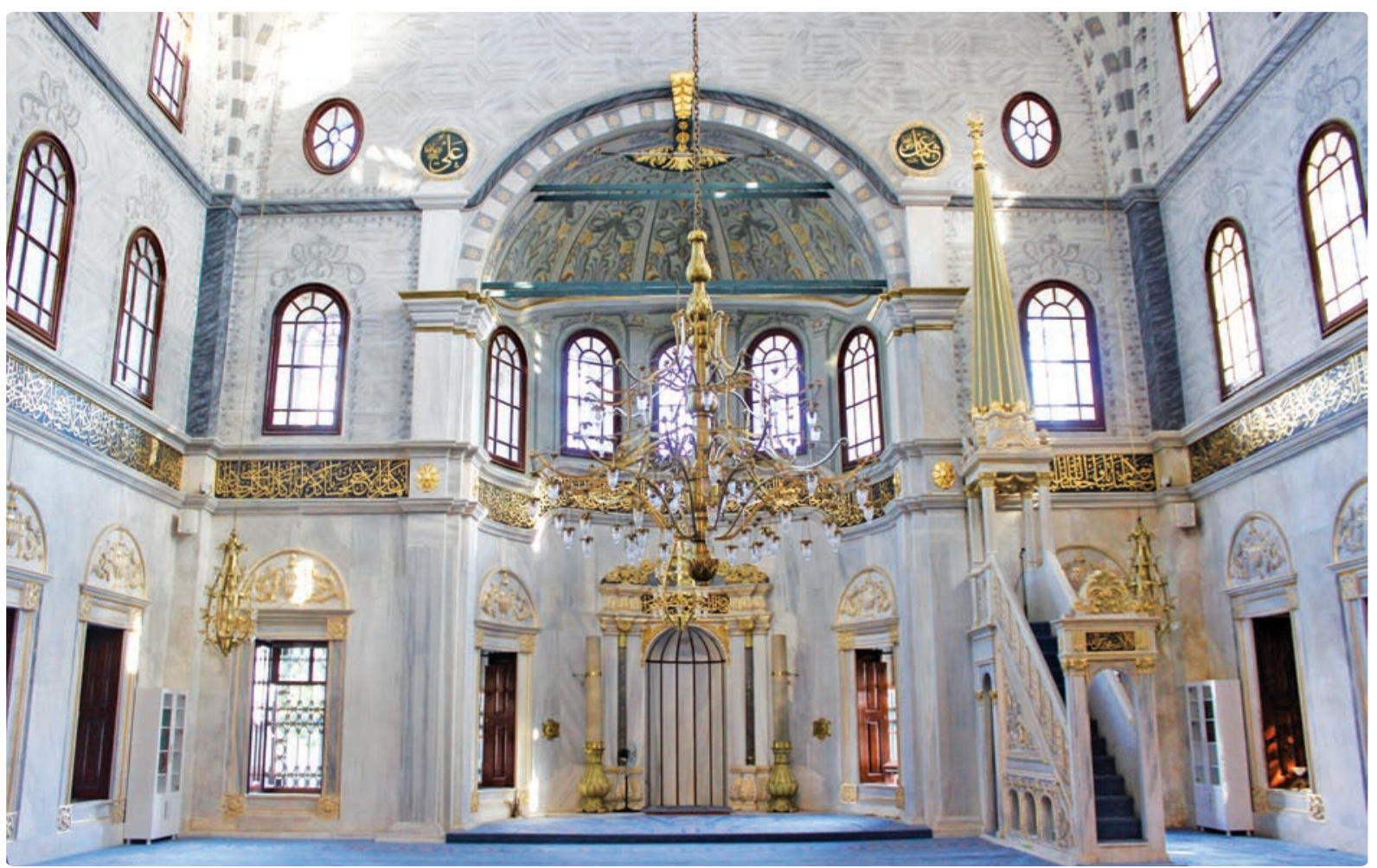

Fotoğraf 20: 2018 onarımları sonrası kalem işi programı. Mibrap duvarından görünüm.

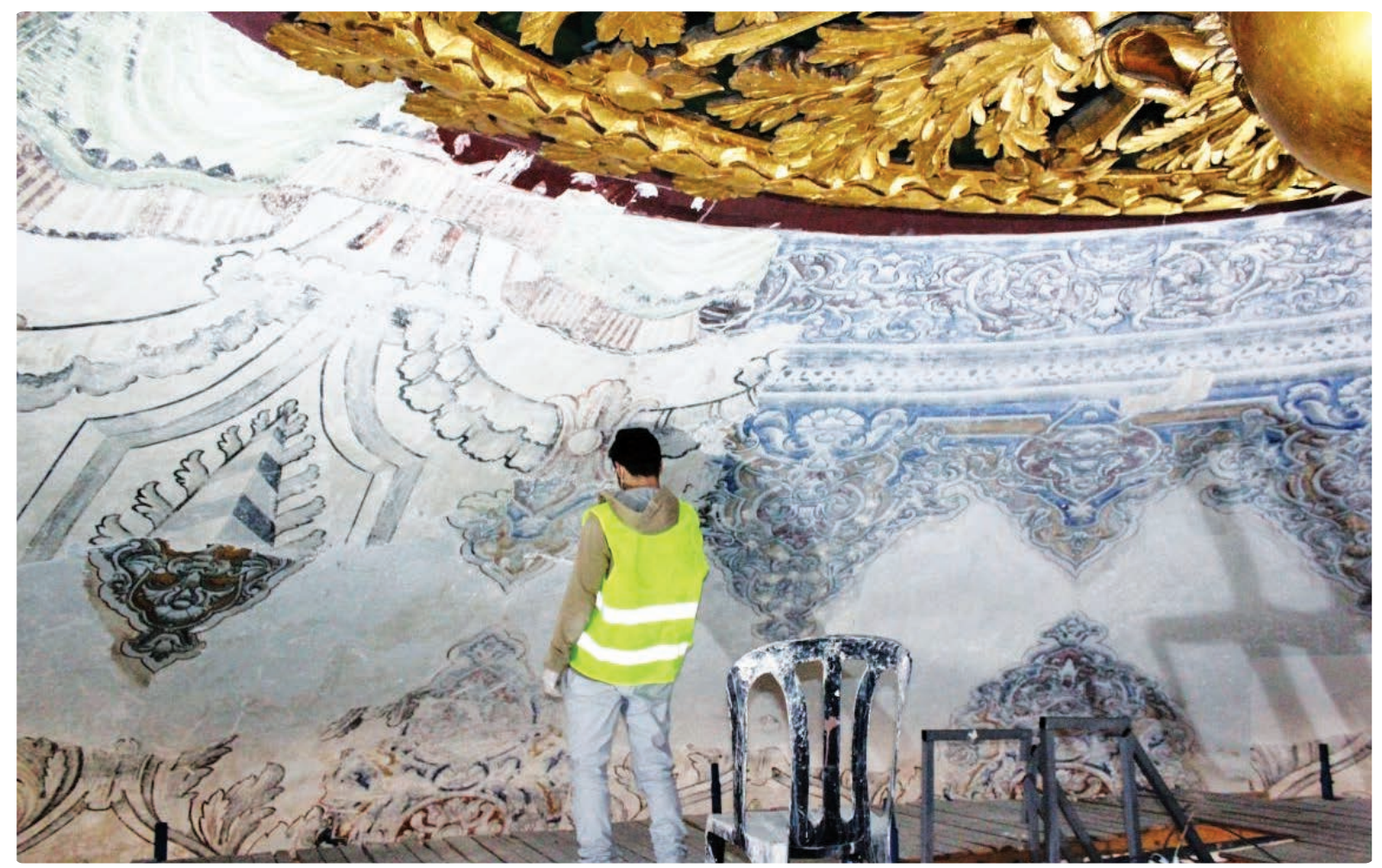

Fotoğraf 21: Onarımlar esnasında kubbedeki kalem işi bezemenin değiştiğini gösteren fotoğraf. (Avunduk Mimarlık Arşivinden) 


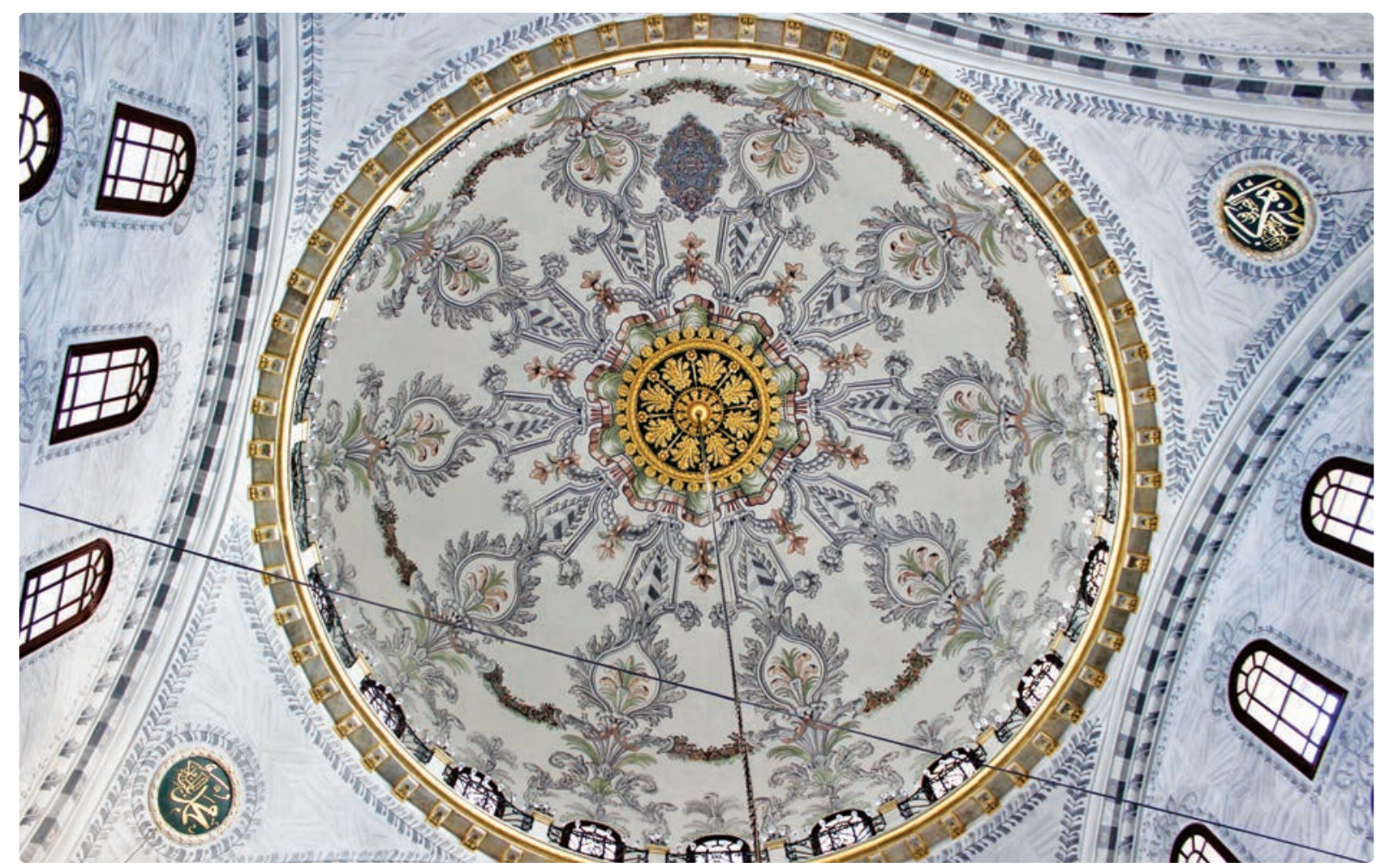

Fotoğraf 22: Nusretiye Camii kubbesi ve intikal elemanları.

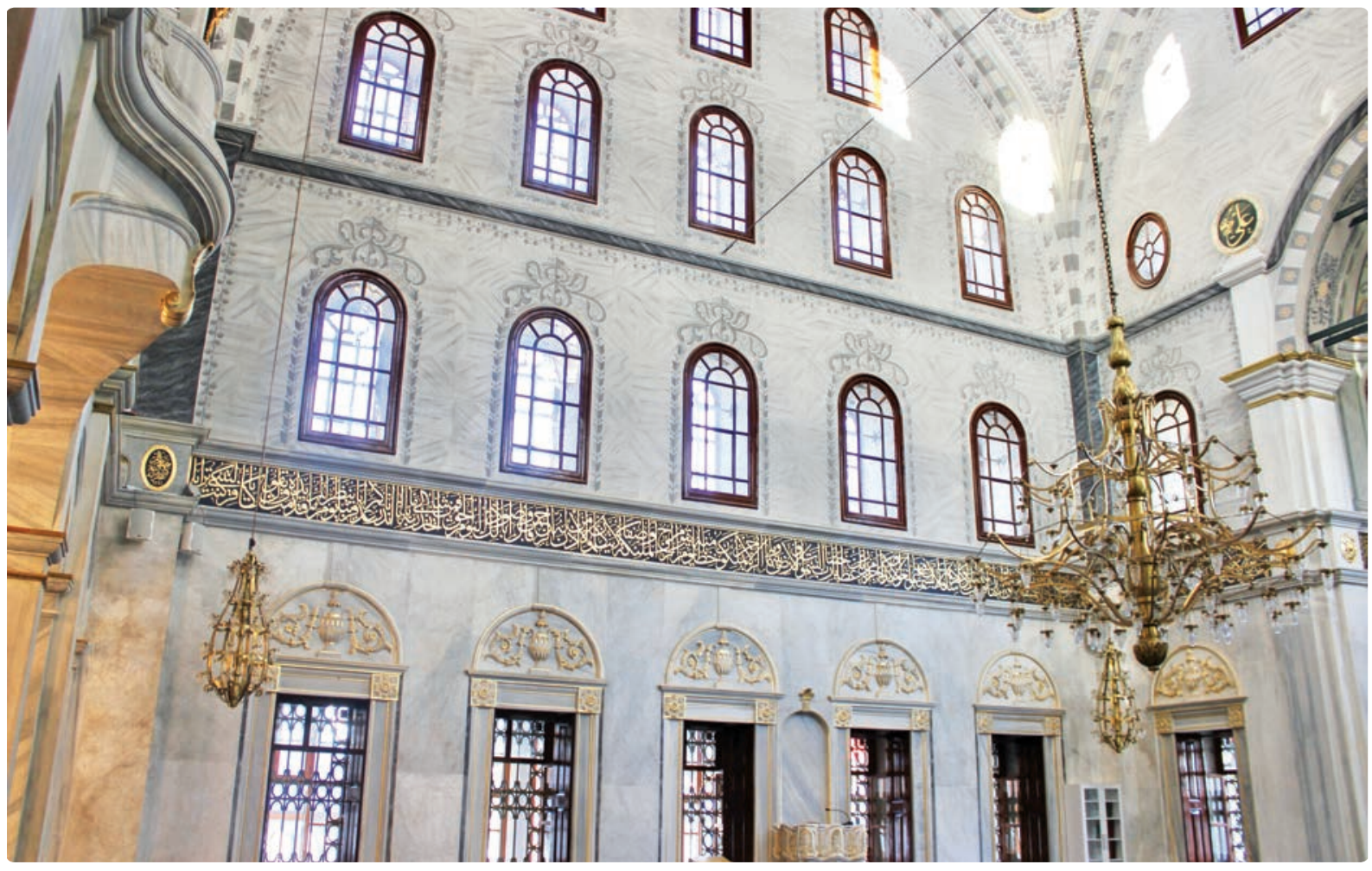

Fotoğraf 23: Doğu harem duvarindan görünüm. 
TARIHSEL KONUMU Ve MIMARISIYLE NUSRETIYE CAMIi

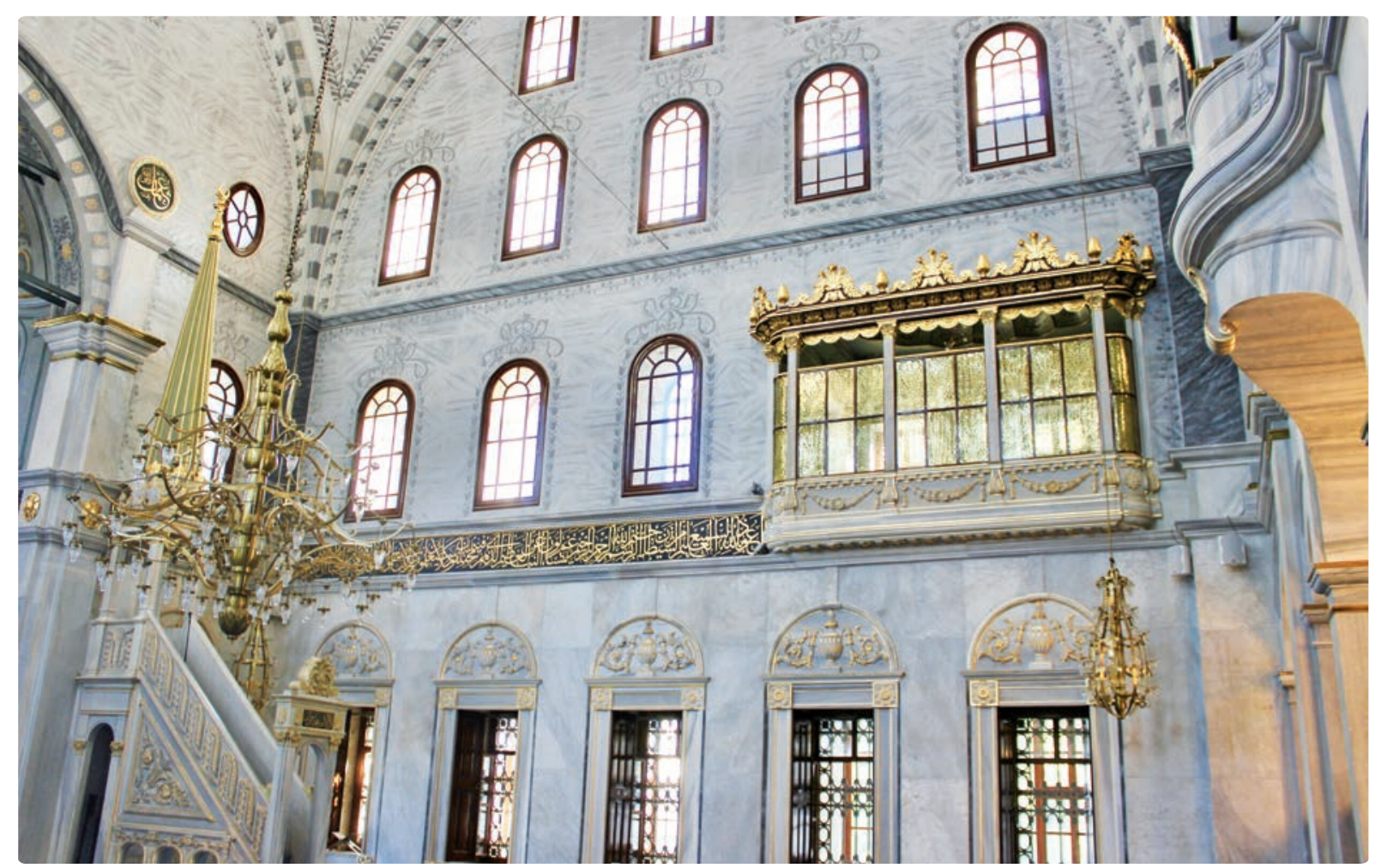

Fotoğraf 24: Batı harem duvarından görünüm.

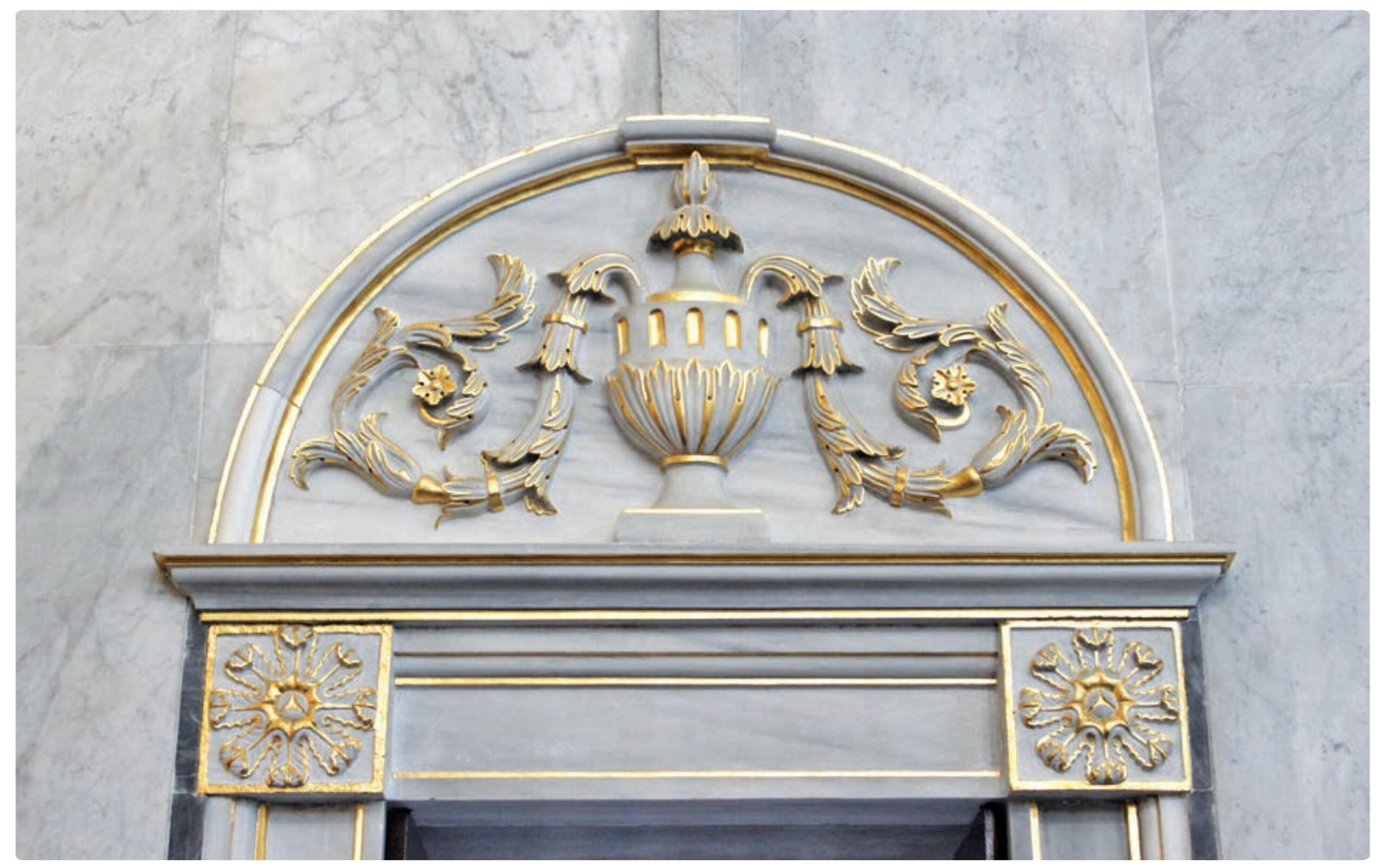

Fotoğraf 25: Harem pencere alınlı̆̆ından detay. 


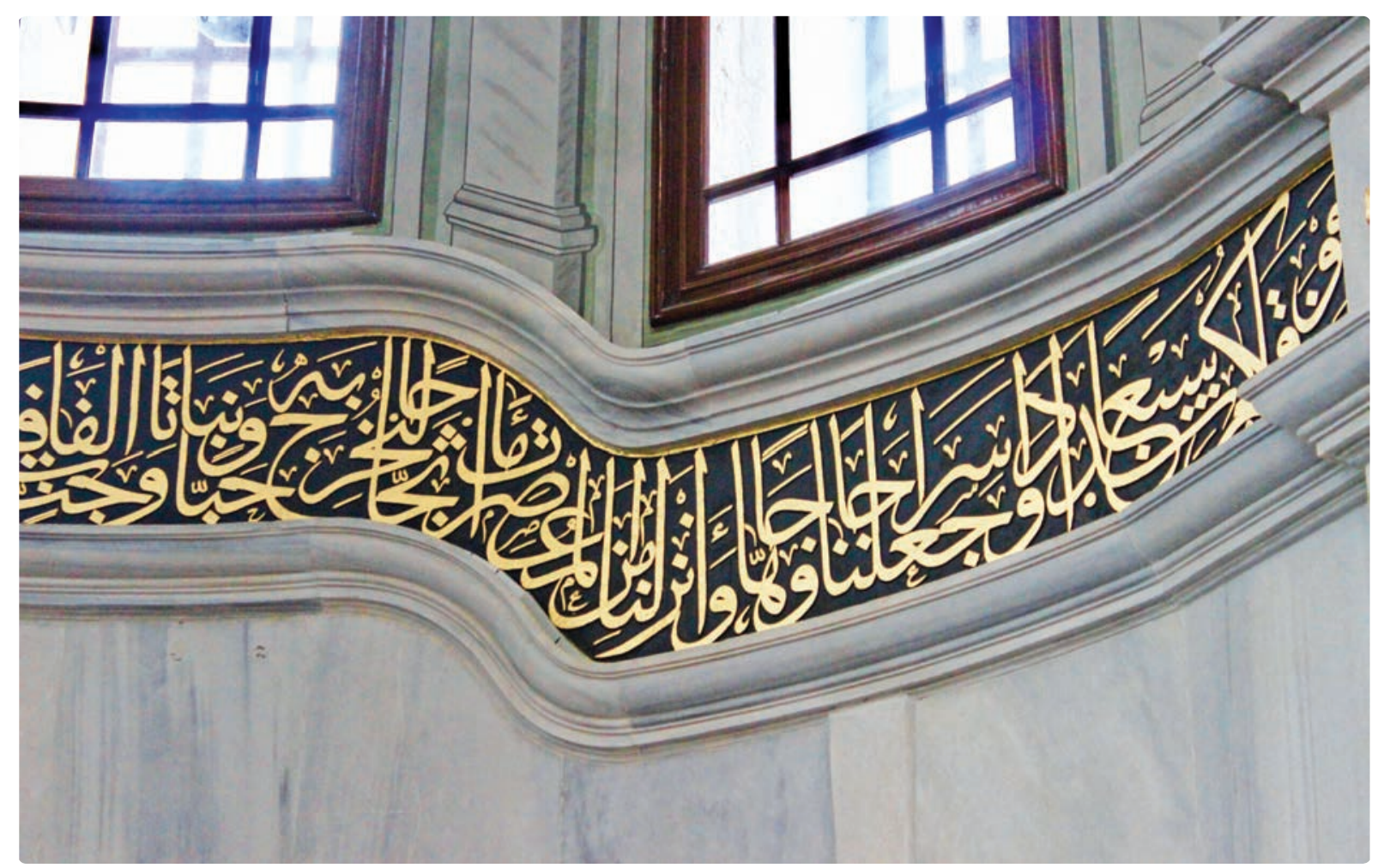

Fotoğraf 26: Kuşak yazısının mibrap nişinde kavisli hareketi.

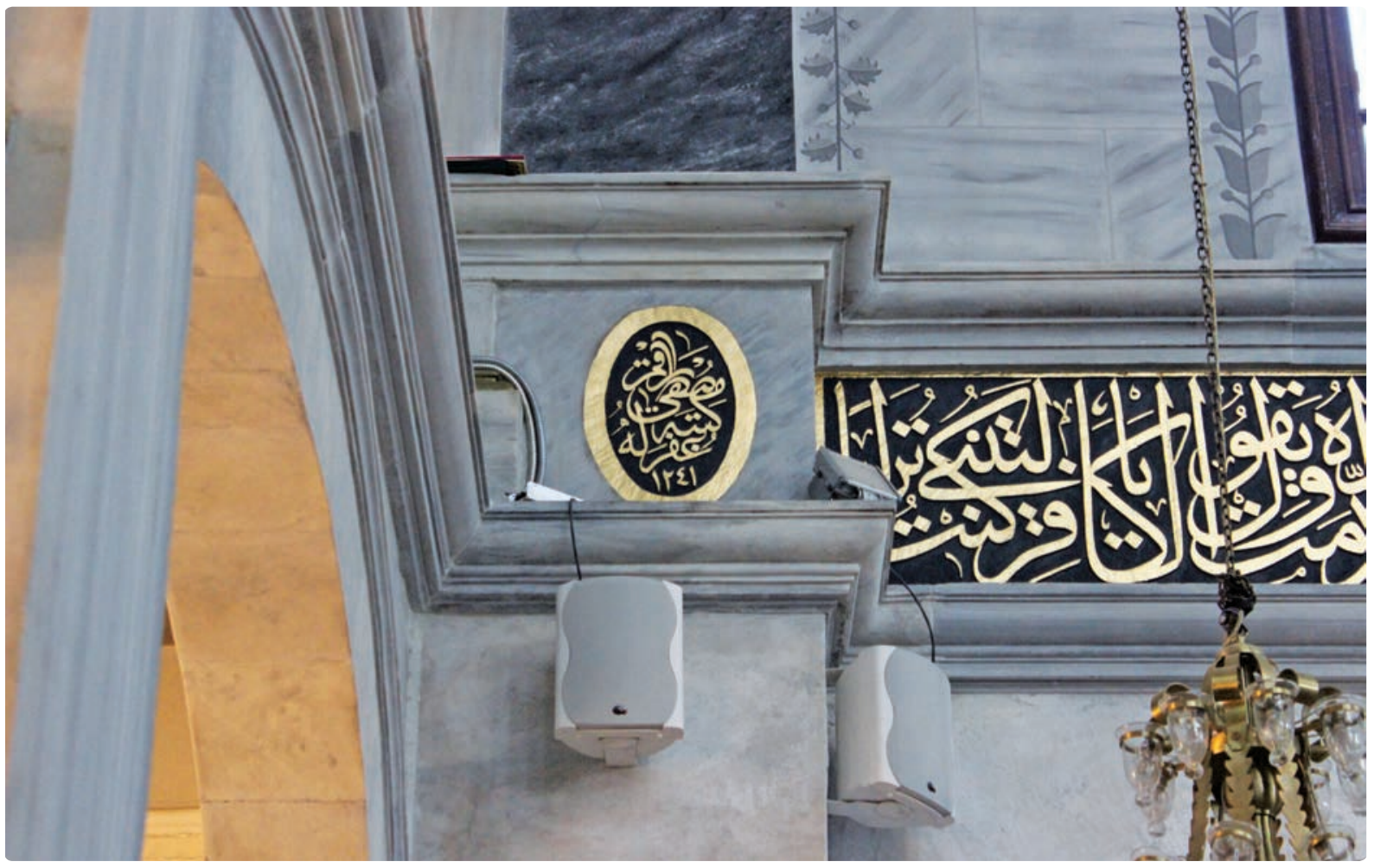

Fotoğraf 27: Kuşak sonunda hattatın madalyon içindeki imzası. 
TARIHSEL KONUMU Ve MIMARISIYLE NUSRETIYE CAMIi

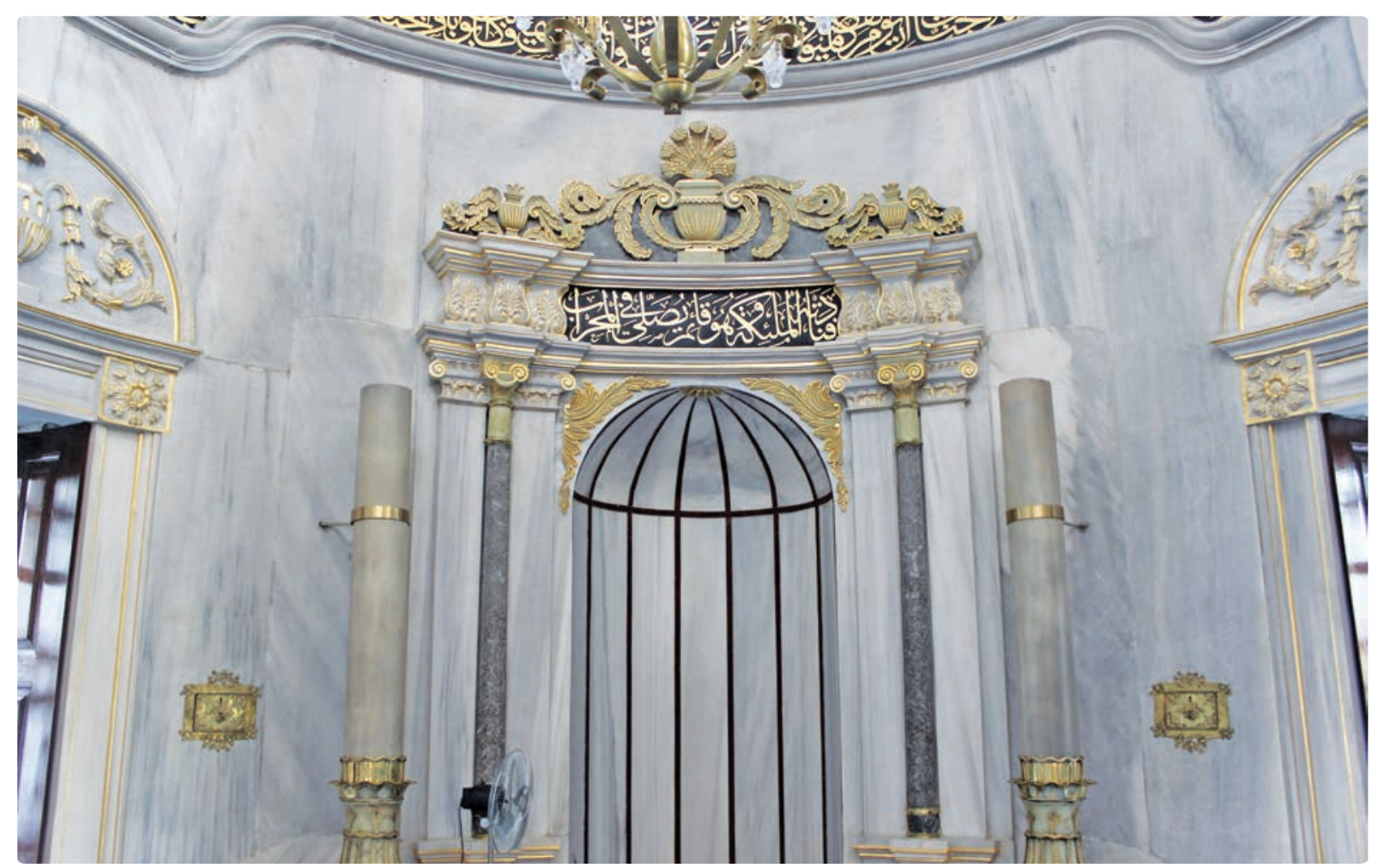

Fotoğraf 28: Nusretiye Camii mibrabı.

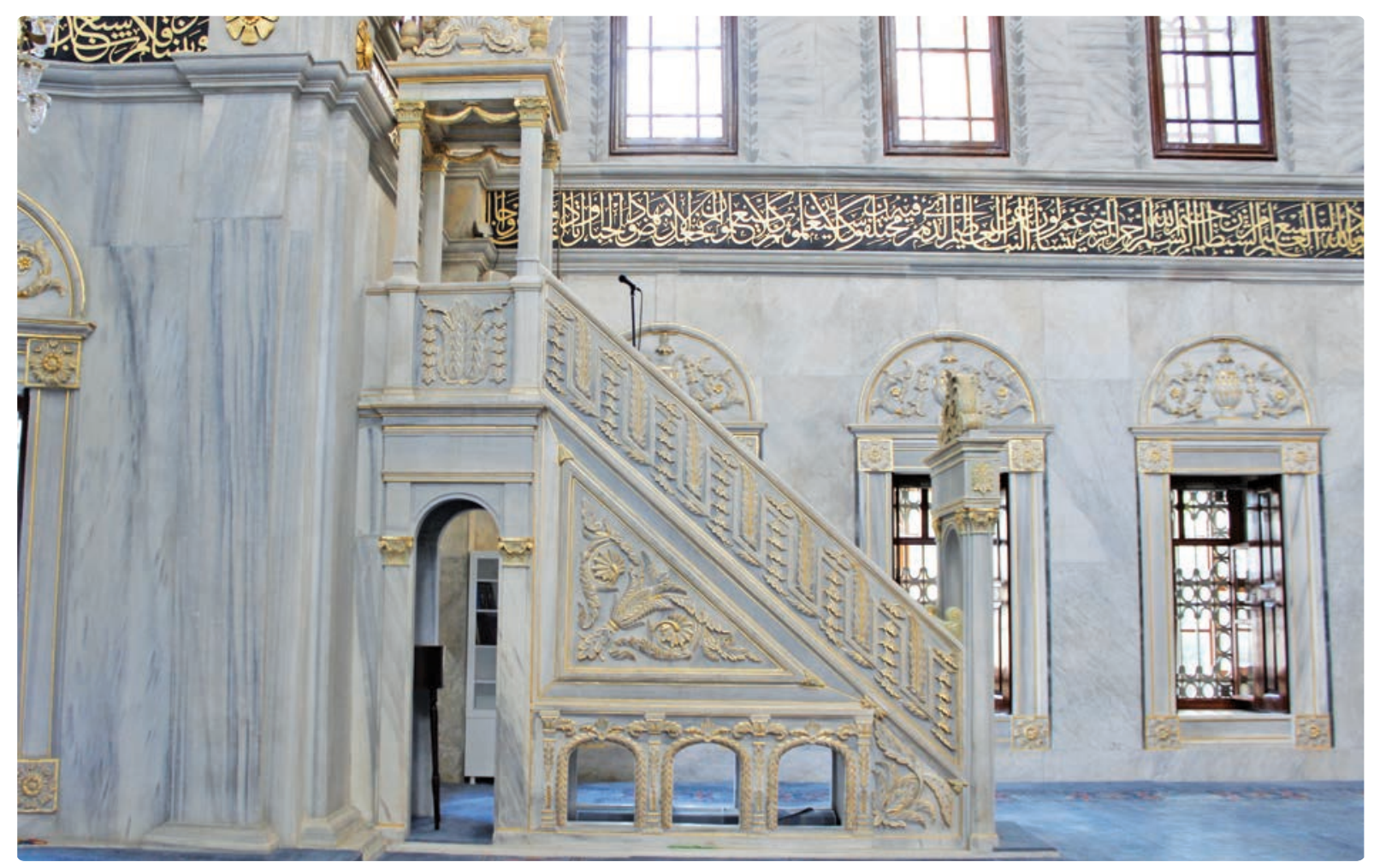

Fotoğraf 29: Nusretiye Camii minberi. 


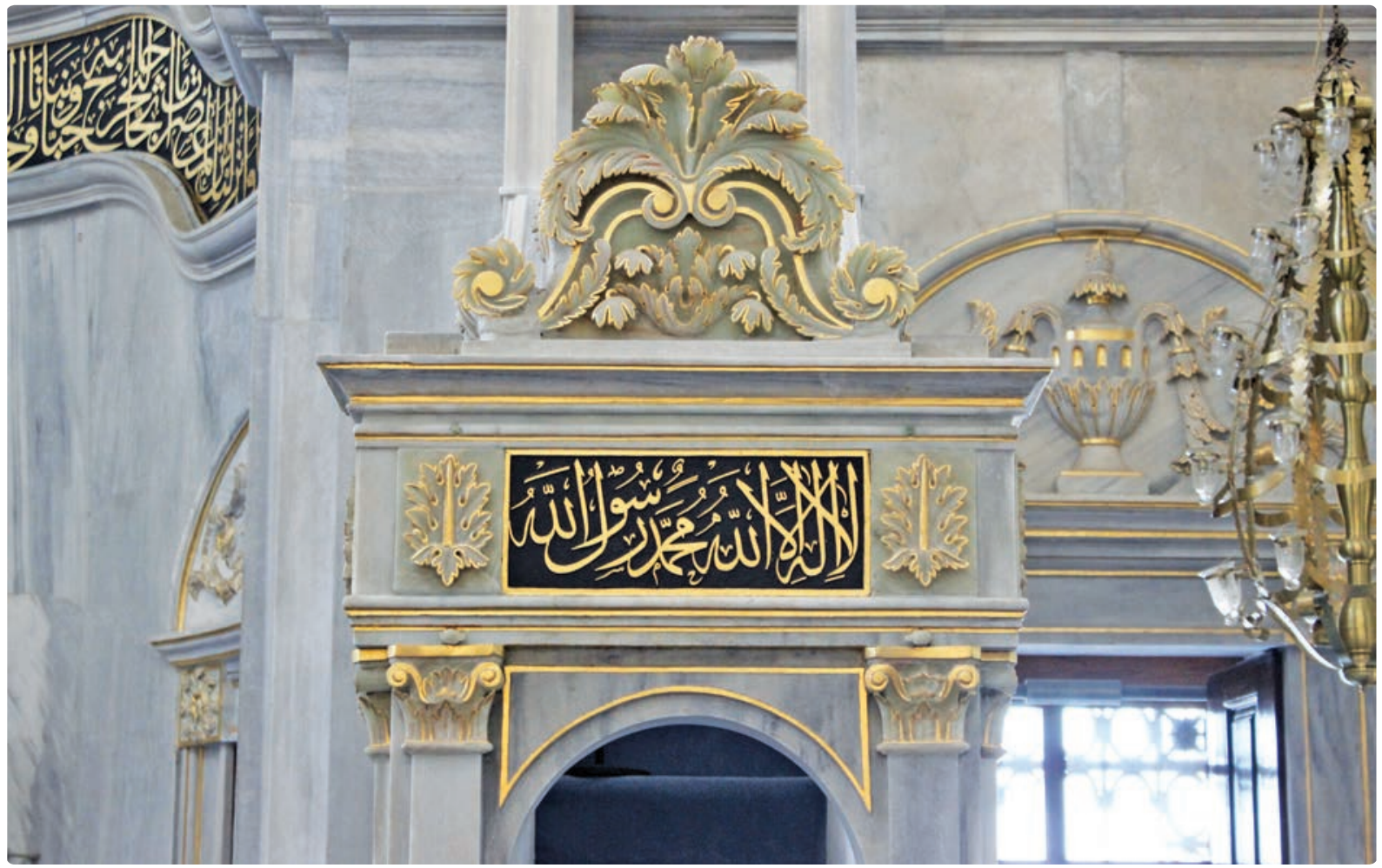

Fotograf 30: Nusretiye Camii minber detayl.

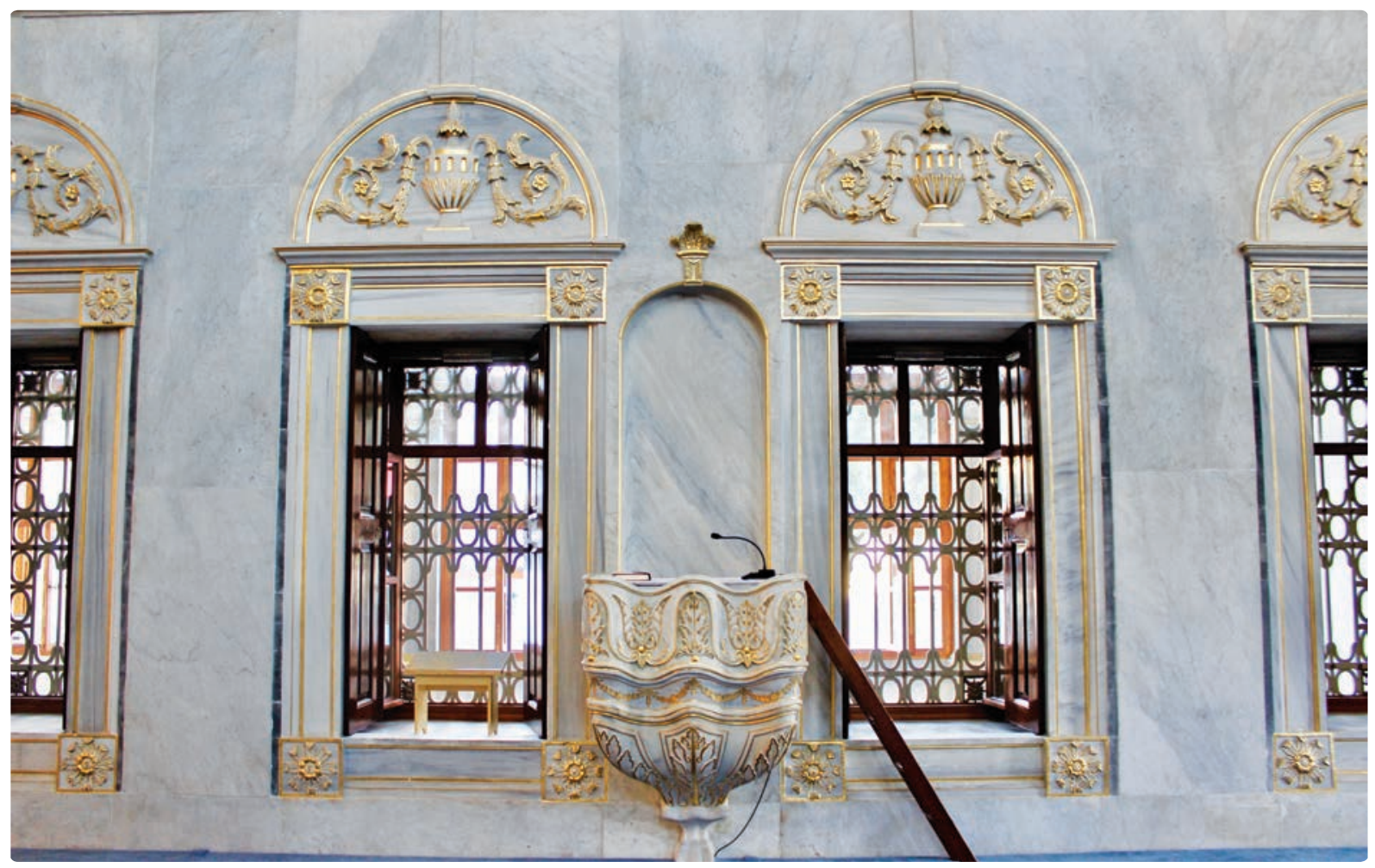

Fotoğraf 31: Nusretiye Camii vaaz kürsüsü. 
TARIHSEL KONUMU Ve MIMARISIYLE NUSRETIYE CAMII

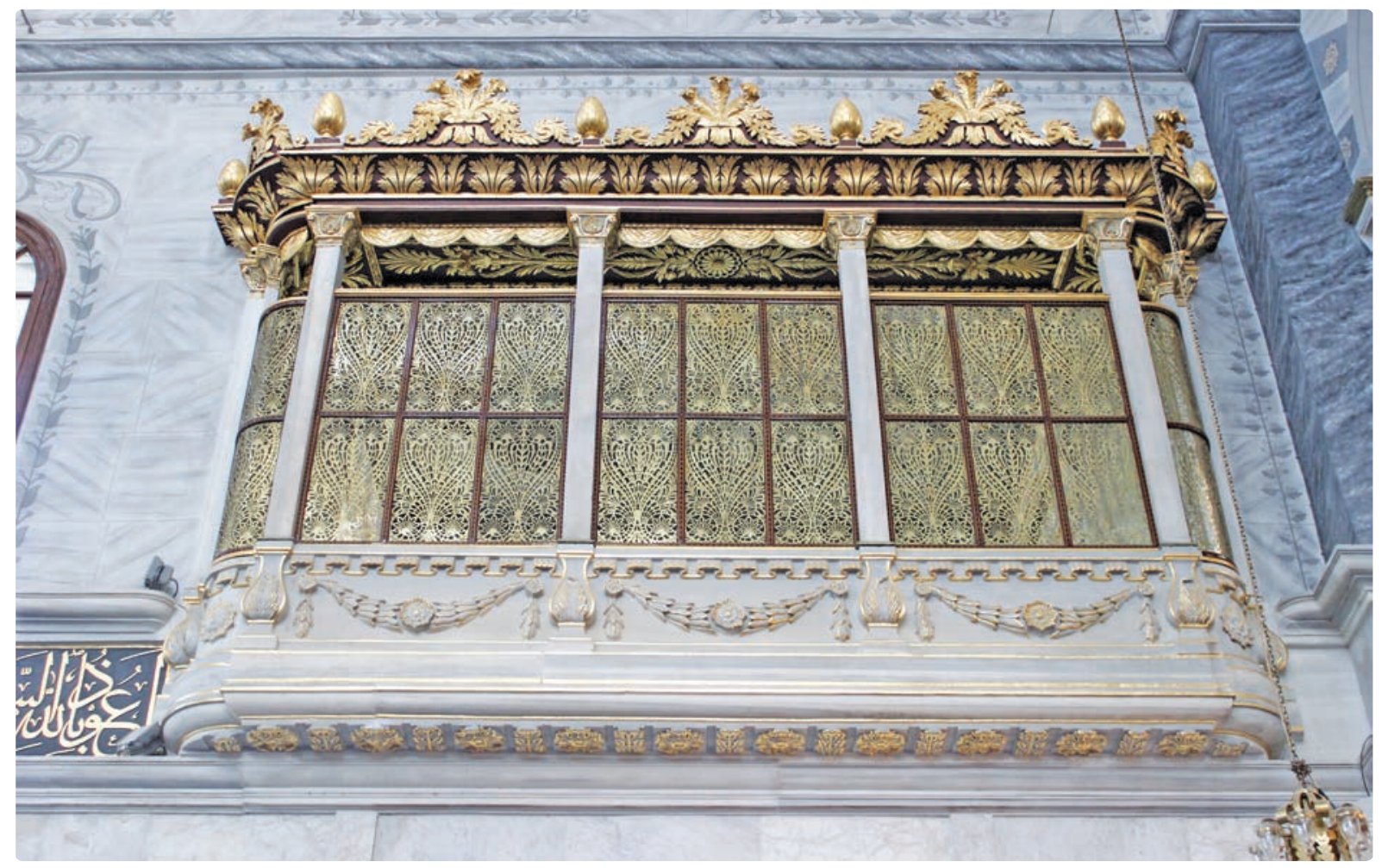

Fotograf 32: Nusretiye Camii bünkar mahfili.

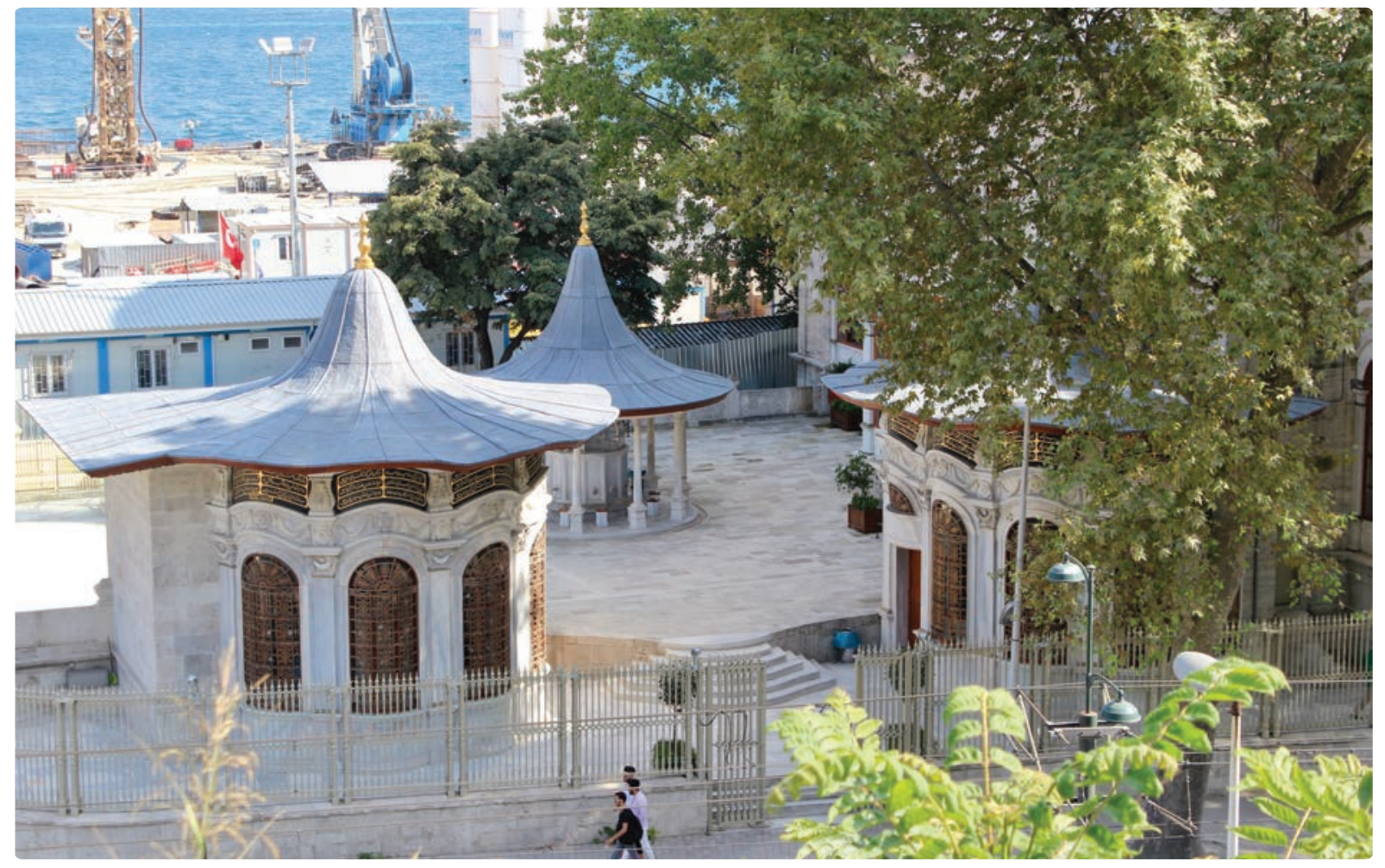

Fotoğraf 33: Nusretiye Camii sebil ve muvakkithanesinin konumu. 
Dursun ARSLAN

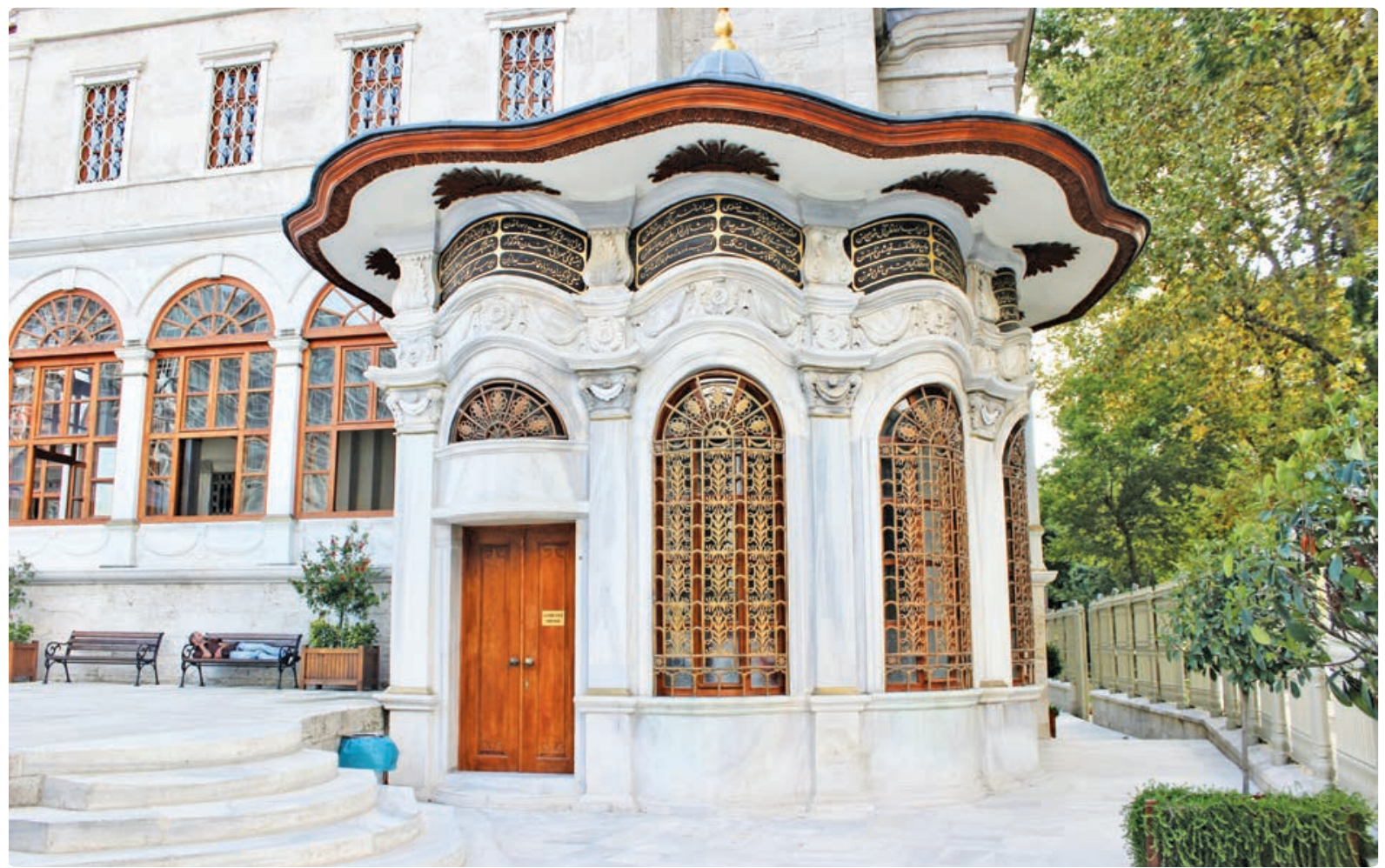

Fotoğraf 34: Nusretiye Camii muvakkithanesi.

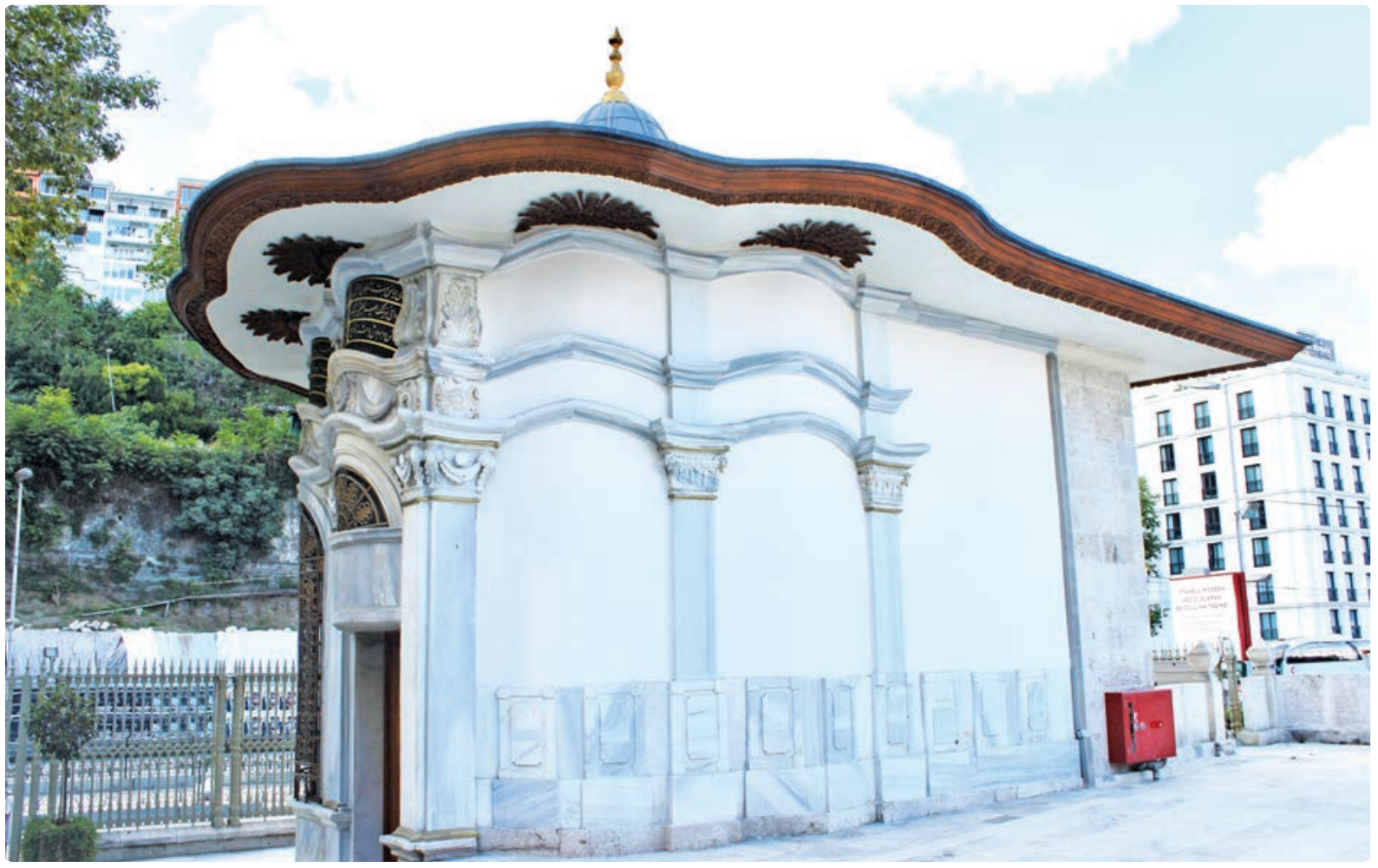

Fotoğraf 35: Nusretiye Camii sebil arka cephesi. 
TARIHSEL KONUMU Ve MIMARISIYLE NUSRETIYE CAMII

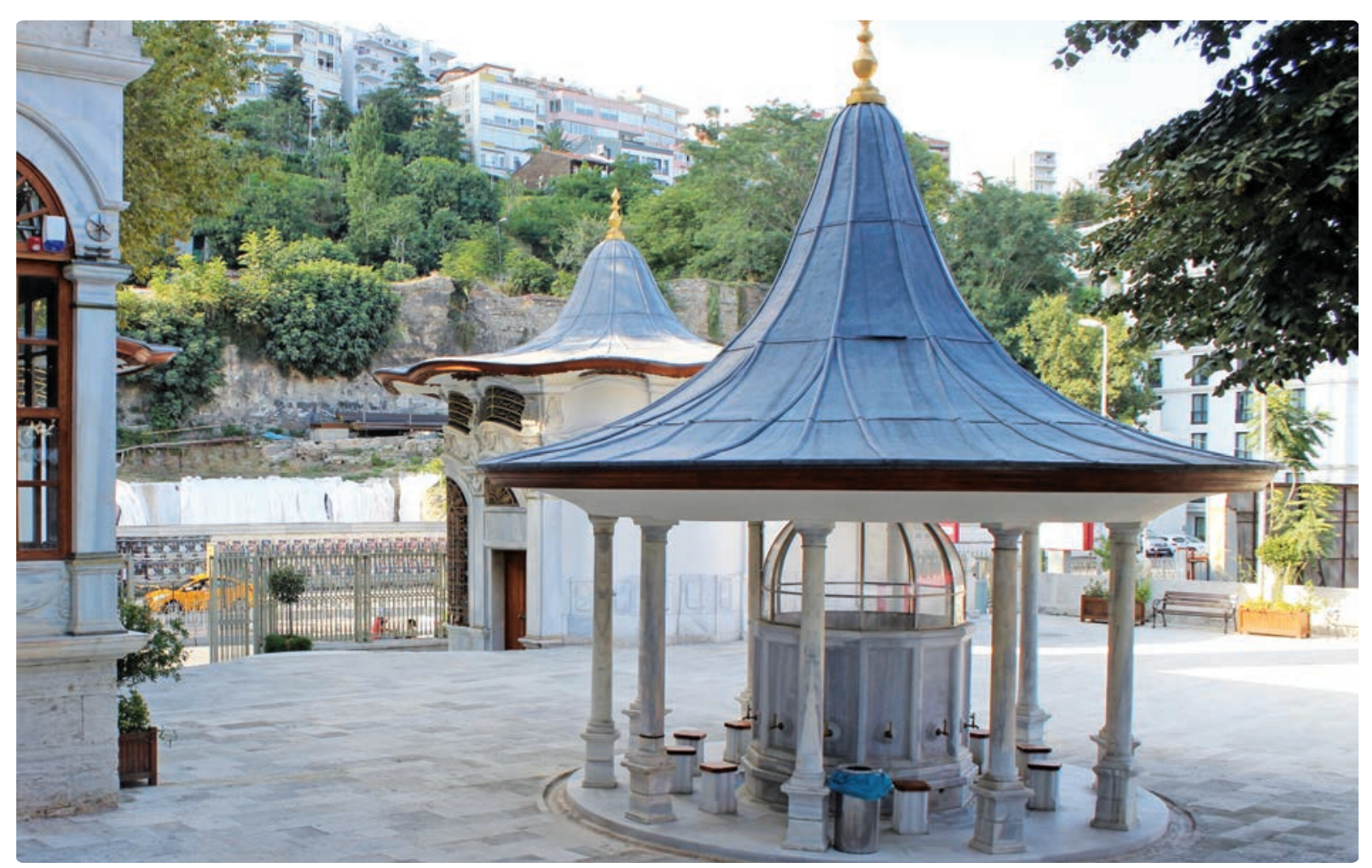

Fotoğraf 36: Nusretiye Camii şadırvanı.

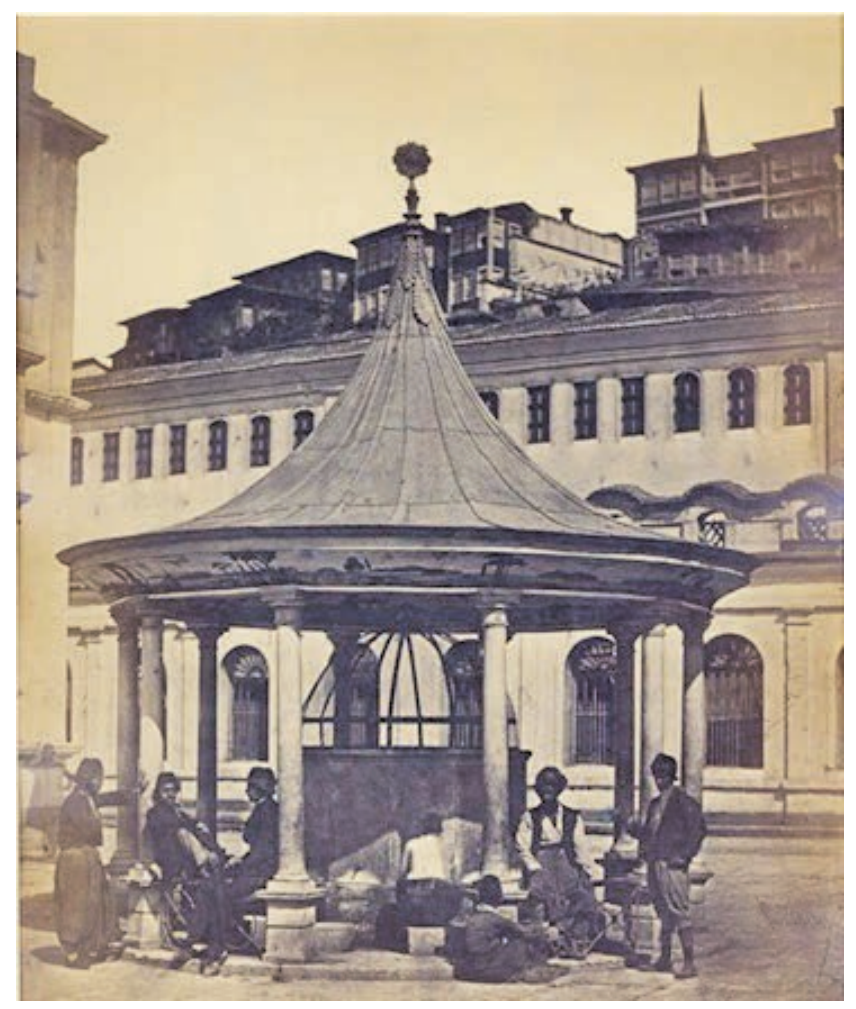

Fotoğraf 37: Nusretiye Camii şadırvanı. (James Robertson 1850-55) 


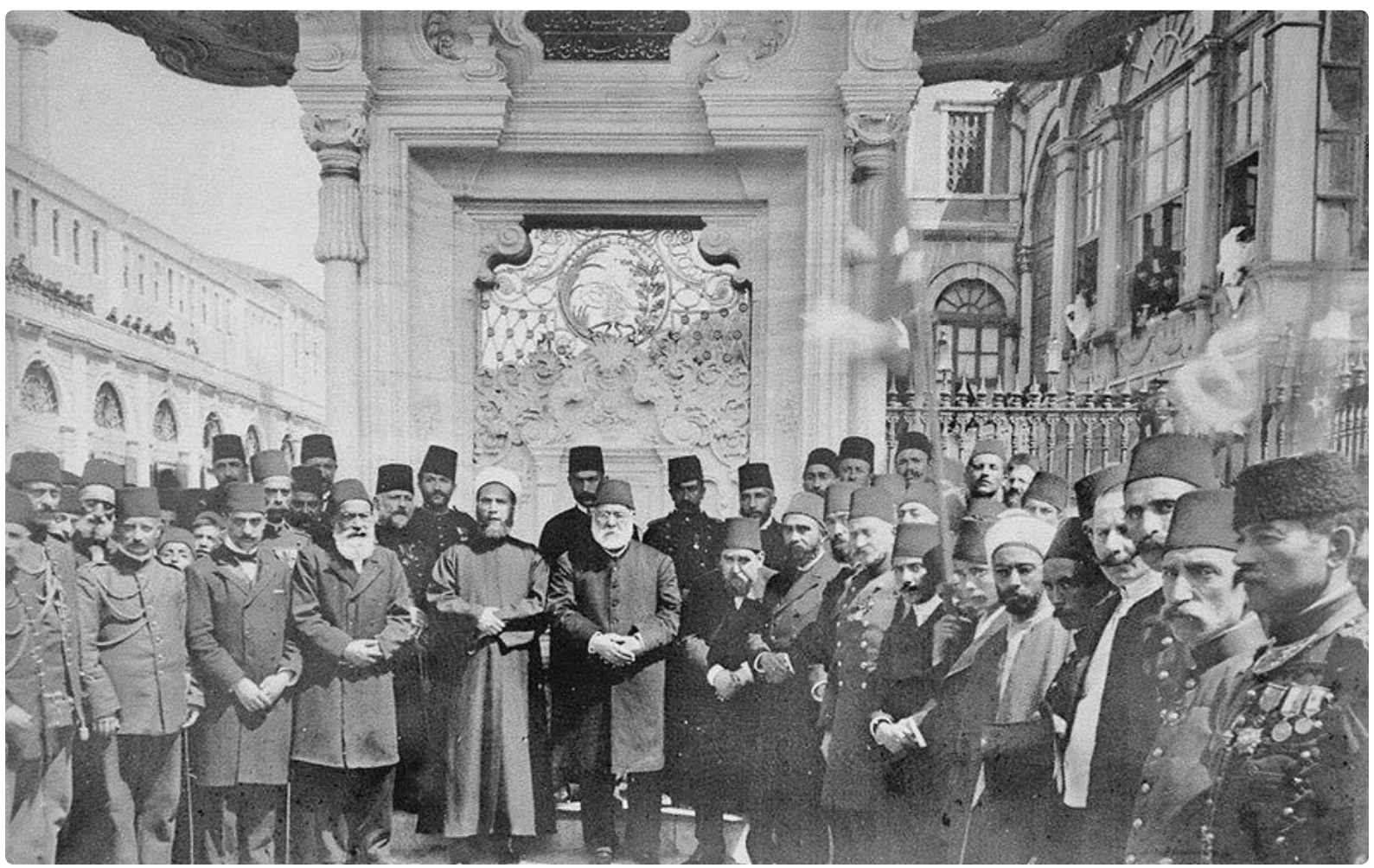

Fotoğraf 38: Nusretiye Camii önünde Hamidiye Çeşmesinin açılıs̆ 1897.

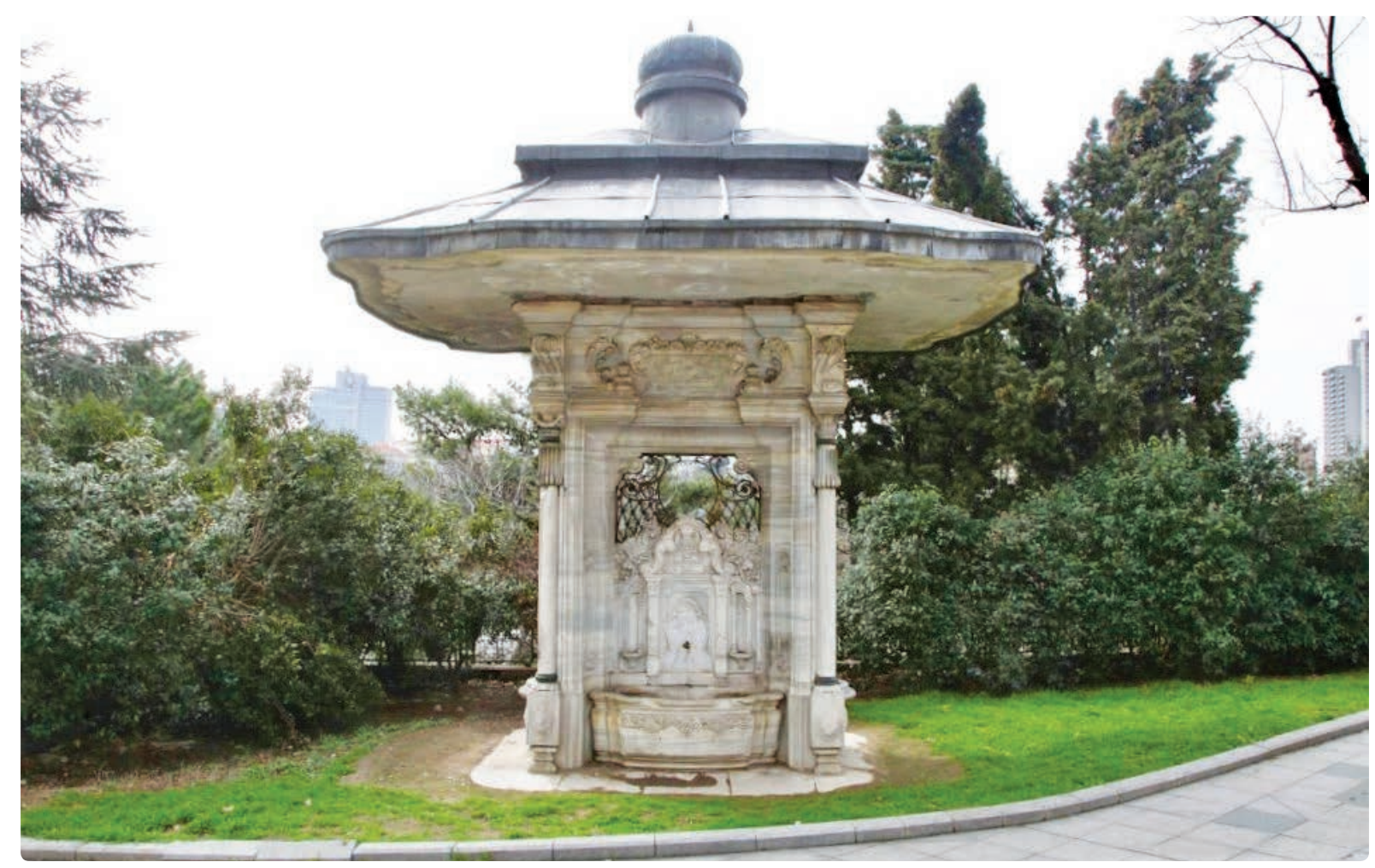

Fotoğraf 39: Hamidiye Çeşmesi, Maçka’ya taşındıktan sonra. 


\section{KAYNAKÇA}

Aslanapa, Oktay, (2004). Osmanlı Devri Mimarisi, İnkılap Yay., İstanbul.

Ayvansarayi Hüseyin Efendi, Hadîkat'ül Cevâmi, Hadikatüll Ceva-mi (2. Bölüm), İstanbul, H. 1281, s. 63-65.

Ayvansarayi Hüseyin Efendi, (2001). Hadîkat'ül Cevâmi İstanbul Camileri ve Diğer Dini Sivil Mimari Yapılar, İstanbul, s. 461-463.

Can, Selman, (2010). Bilinmeyen Olayları ve Aktörleri İle Son Dönem Osmanlı Mimarlı̆̆ı, Erzurum İl ve Kültür Tur. Bak., İstanbul.

Cezar, Mustafa, (2002). Osmanlı Başkenti İstanbul, EKAV. Vakfi Yay., İstanbul.

Çelik, Zeynep, (2015). 19. Yüzyılda Osmanlı Başkenti; Değişen İstanbul, T.C. İş Bank. Yay., İstanbul.

Çetintaş, M. Burak, (2005). Dolmabahçe'den Nişantaşı’na, Antik A.Ş. Kültür Yay., İstanbul.

Develioğlu, Ferid, (2013). Osmanlıca-Türkşe Ansiklopedik Lûgat, Aydın Kitabevi Yay., Ankara.

Ertuğ, Necdet (Edtr.), (2006). İstanbul Tarihi Çeşmeler Külliyatı, İSKİ. Gen. Müd. Yay., İstanbul.

Eyice, Semavi, (2007). “Nusretiye Camii”, TDV İslâm Ansiklopedisi, Cilt. 33, Ankara, s. 274-276.

Kuban, Doğan, (2016). Osmanlı Mimarisi, YEM Yay., İstanbul.

Kumbaracilar, İzzet, (2008). İstanbul Sebilleri, Kap1 Yay., İstanbul.

Mehmed Raif, (H.1314). Mir'at-ı İstanbul, İstanbul.

Özkafa, Fatih, (2008). İstanbul Selâtin Camilerinin Kuşak Yazıları, Yayımlanmamış Doktora Tezi, Konya.

Öz, Tahsin, (1997). İstanbul Camileri, TTK. Yay., Ankara.

Pehlivan Nuran, Urfalıŏlu Nur, Yazıcıoğlu Lütfi, (2000). Osmanlı Başkenti İstanbul'da Çeşmeler, YEM Yay., İstanbul.

Şerifoğlu, Ömer Faruk, (1995). Su Güzeli; İstanbul Sebilleri, İBB. Kült. Yay., İstanbul.

Tali, Şerife, (2011). Taribi İstanbul Camilerinde Şadırvanlar, Ankara. 